\title{
Nitrogen and Phosphorus Loading from Drained Wetlands Adjacent to Upper Klamath and Agency Lakes, Oregon
}

U.S. GEOLOGICAL SURVEY Water-Resources Investigations Report 97-4059

Prepared in cooperation with the BUREAU OF RECLAMATION

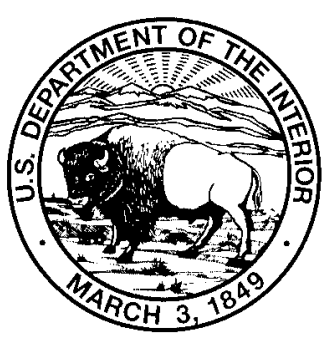




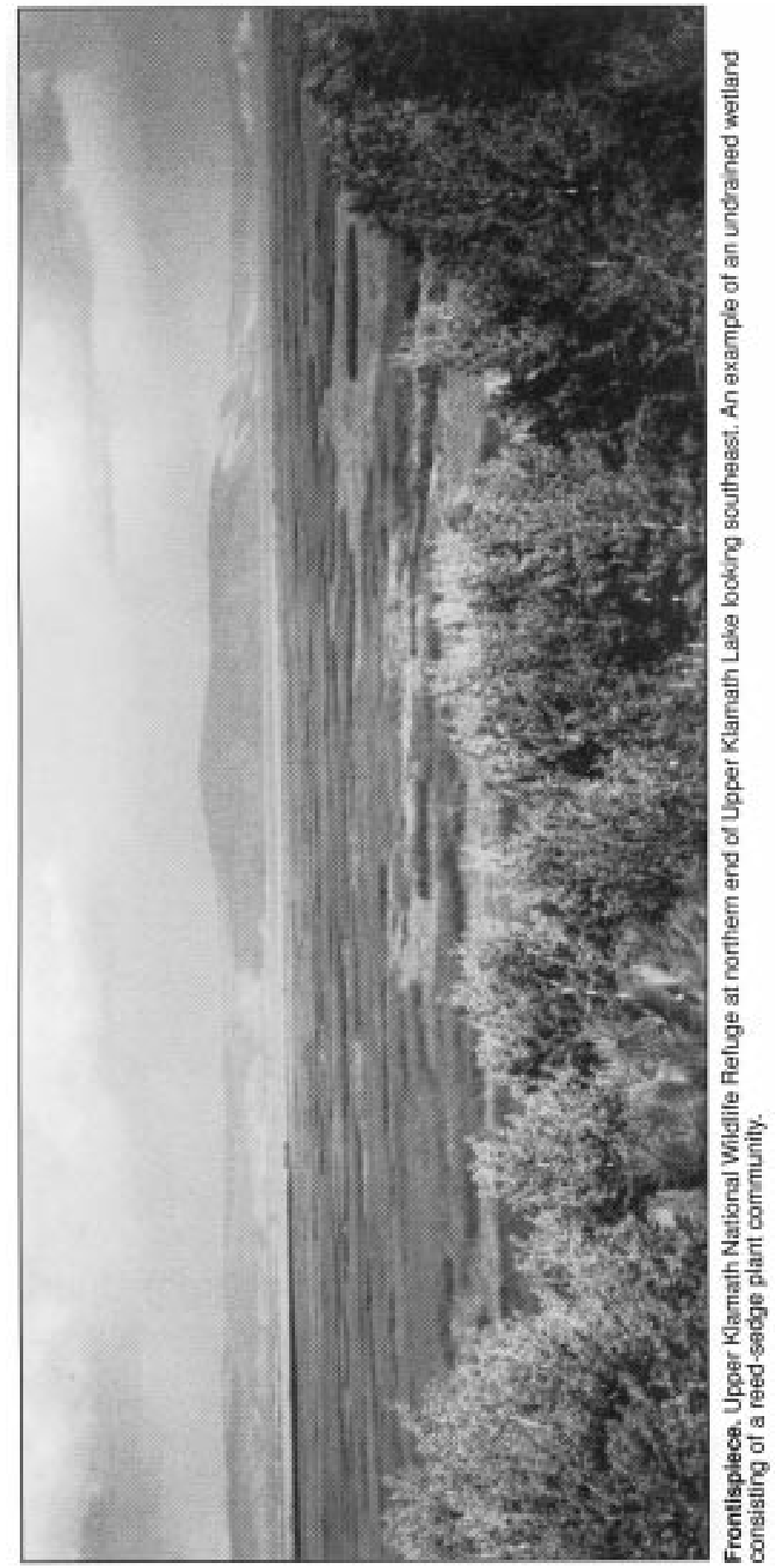




\section{Nitrogen and Phosphorus Loading from Drained Wetlands Adjacent to Upper Klamath and Agency Lakes, Oregon}

By Daniel T. Snyder and Jennifer L. Morace

\section{U.S. GEOLOGICAL SURVEY} Water-Resources Investigations Report 97-4059

Prepared in cooperation with the BUREAU OF RECLAMATION

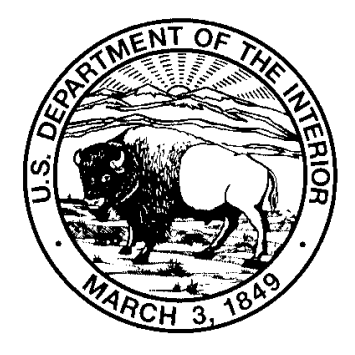




\section{U.S. DEPARTMENT OF THE INTERIOR \\ BRUCE BABBITT, Secretary}

U.S. GEOLOGICAL SURVEY

Gordon P. Eaton, Director

Any use of trade, product, or firm names in this publication is for descriptive purposes only and does not imply endorsement by the U.S. Government.

For additional information contact:

District Chief

U.S. Geological Survey, WRD

10615 S.E. Cherry Blossom Drive

Portland, OR 97216-3159

E-mail: info-or@usgs.gov

Internet: <http://oregon.usgs.gov>
Copies of this report can be purchased from:

U.S. Geological Survey Branch of Information Services Box 25286, Federal Center Denver, CO 80225-0046 


\section{CONTENTS}

Definition of Terms

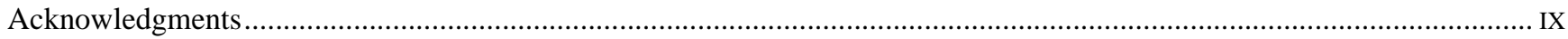

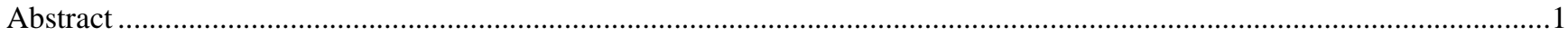

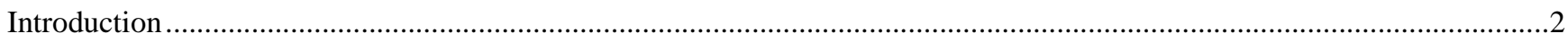

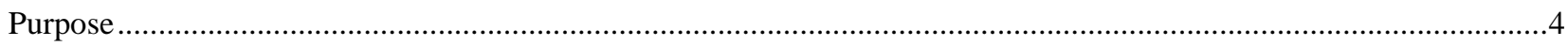

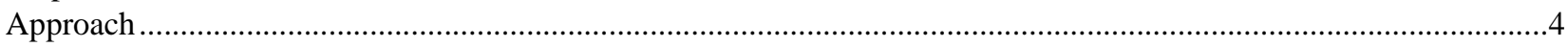

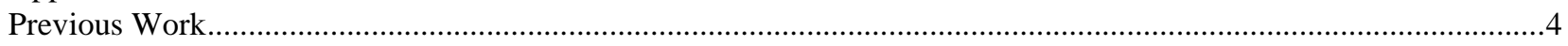

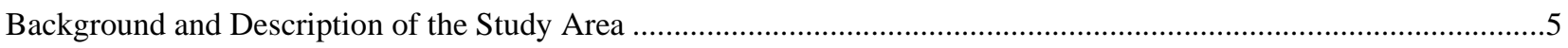

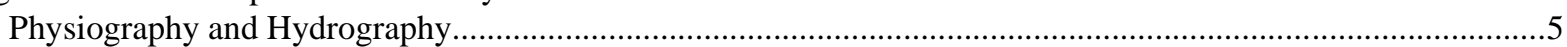

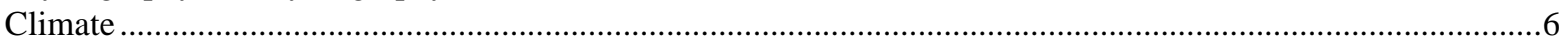

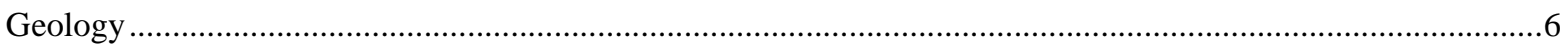

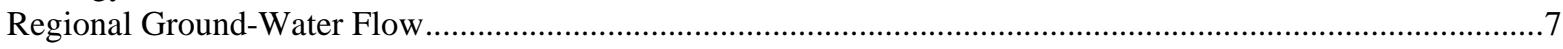

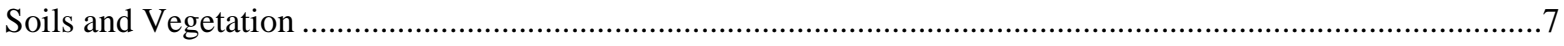

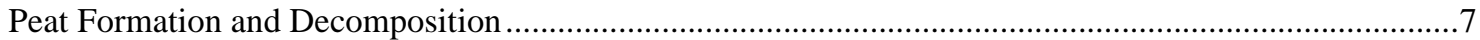

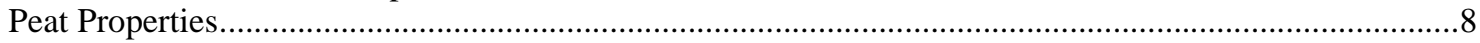

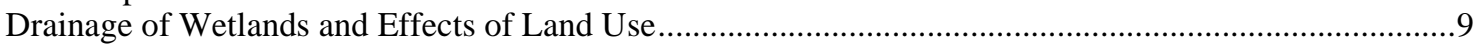

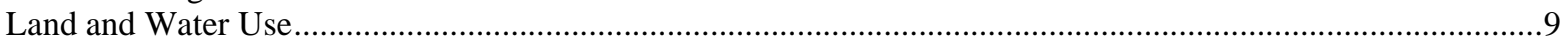

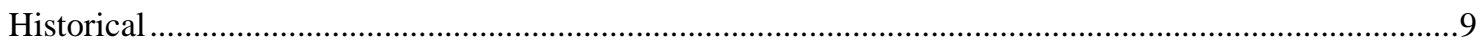

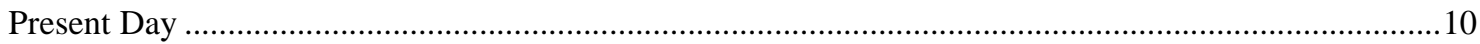

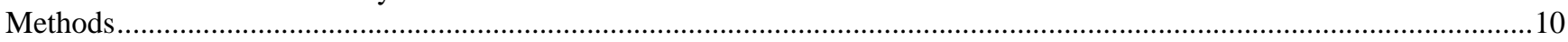

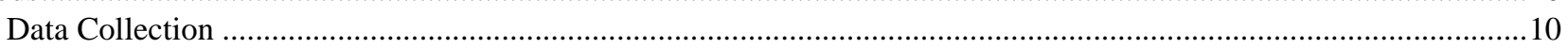

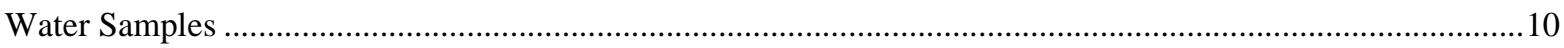

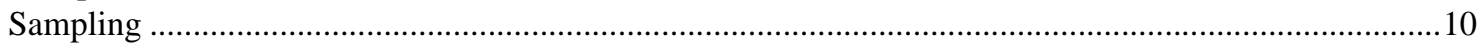

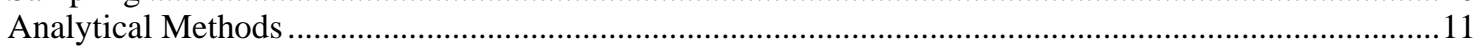

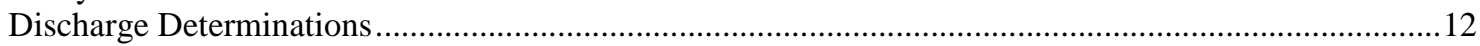

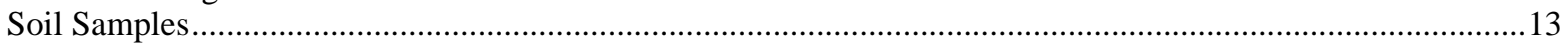

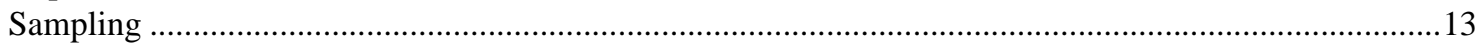

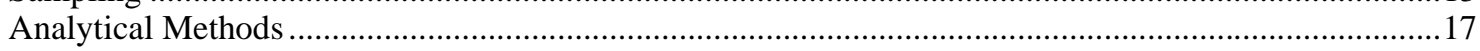

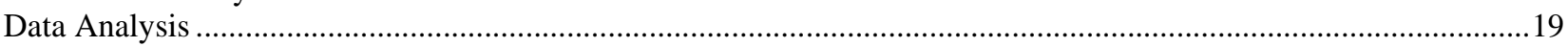

Estimation of Nutrient Loads Using Sampling and Measurement of Pump Discharge.......................................19

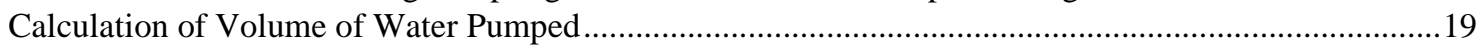

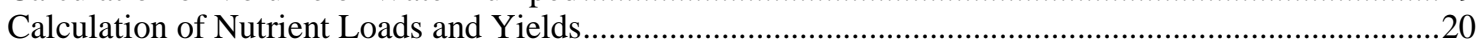

Limitations and Concerns Involved in Calculations of Nutrient Loads and Yields ....................................20

Estimation of Nutrient Loss Using Change in Nutrient Mass of Drained Wetland Soils.....................................21

Calculation of Present-Day Peat and Nutrient Masses ..............................................................................21

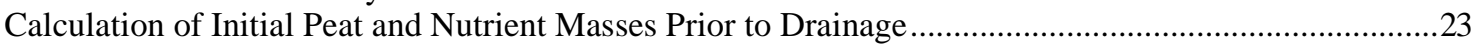

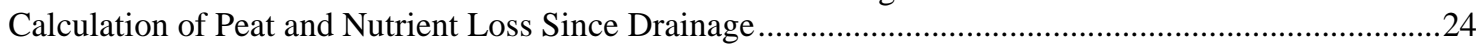

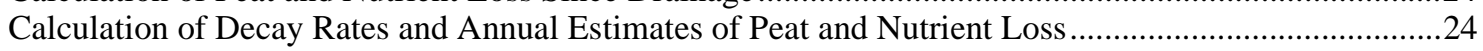

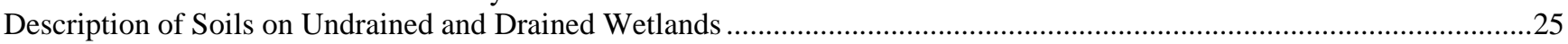

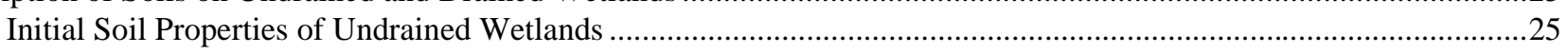

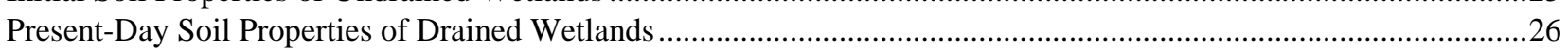

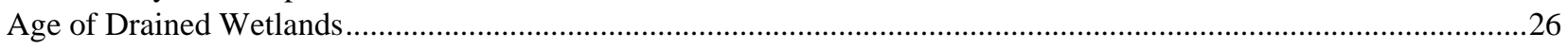

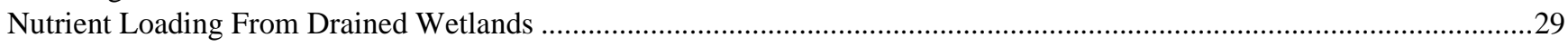

Discussion of Nutrient Loads and Yields from Pump Discharge ........................................................................29

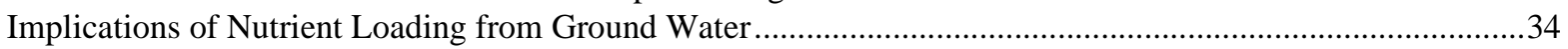

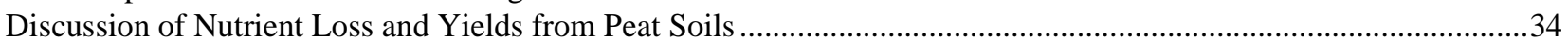

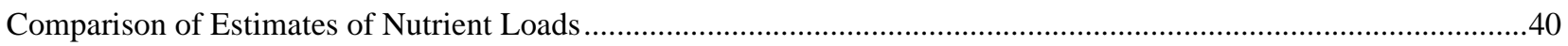

Nutrient Loads from Peat Soils and Discharge Pumps ...................................................................................

Nutrient Loads from Peat Soils and Estimates by Miller and Tash .................................................................4

Nutrient Loss from Upper Klamath Lake Peat Soils and Estimates for Other Wetlands ...................................41

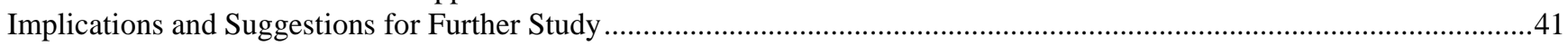

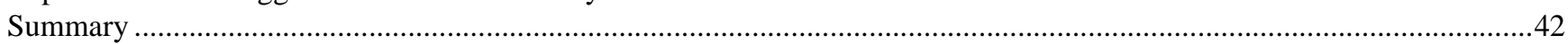

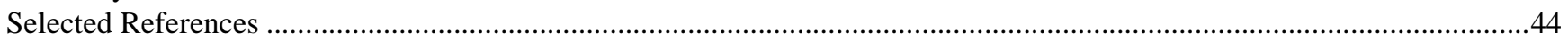




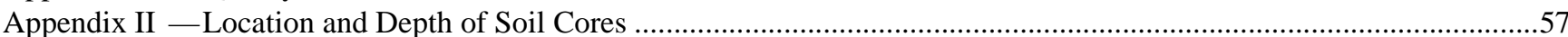

PLATES

[ In pocket ]

1. Location and lithology of soil cores examined from drained and undrained wetlands adjacent to Upper Klamath and Agency Lakes, Oregon-Northern Part

2. Location and lithology of soil cores examined from drained and undrained wetlands adjacent to Upper Klamath and Agency Lakes, Oregon-Southern Part

\section{FIGURES}

1. - 3. Maps showing:

1. Upper Klamath Lake Basin and vicinity.

2. Location of selected drained wetlands, pumping stations, and flowing artesian wells adjacent to Upper Klamath Lake, Oregon.

3. Location of core sites in the drained and undrained wetlands .................................................................. 14

4. Photographs showing method of soil-core collection from drained and undrained wetlands ................................16

5. Diagram showing calculation of peat and nutrients of a drained wetland area.................................................22

6. Photographs showing examples of soils cores retrieved using Macaulay peat sampler from drained wetland used for cultivation .

7. Graphs showing statistical summaries of physical and chemical properties of samples from undrained

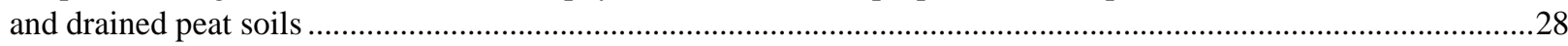

8. Graph showing cumulative area of drained wetlands adjacent to Upper Klamath Lake over time .........................29

9. Graphs showing annual median concentrations, volume of water pumped, load, and yield of total nitrogen and total phosphorus for selected pumping stations adjacent to Upper Klamath Lake,

Oregon, 1993-95 water years.

10. Graphs showing nitrogen loss in drained wetlands, Upper Klamath Lake, Oregon:

A. Estimated annual nitrogen loss in 1994-95 per unit area at each drained wetland...........................................37

B. Estimated cumulative nitrogen loss per unit area at each drained wetland.........................................................37

C. Estimated cumulative nitrogen loss as a percentage of initial nitrogen at each drained wetland ........................37

11. Graphs showing phosphorus loss in drained wetlands, Upper Klamath Lake, Oregon .......................................38

A. Estimated annual phosphorus loss in 1994-95 per unit area at each drained wetland.....................................38

B. Estimated cumulative phosphorus loss per unit area at each drained wetland..................................................38

C. Estimated cumulative phosphorus loss as a percentage of initial phosphorus at each drained wetland ................38

12. Graphs showing rate constants for estimation of nutrient loss using a first-order rate law for each drained area by land use

\section{TABLES}

1. Physical characteristics of Upper Klamath and Agency Lakes, Oregon

2. Methods and minimum reporting levels for nutrients in water sampled adjacent to Upper Klamath Lake, Oregon, 1993-95.

3. Discharge of selected pumping stations and flowing artesian wells adjacent to Upper Klamath Lake, Oregon, 1994-95.

4. Descriptions of drained and undrained wetlands adjacent to Upper Klamath Lake, Oregon, sampled during 1993 and 1995.

5. Methods and detection limits for analyses of soils sampled adjacent to Upper Klamath Lake, Oregon, 1995.

6. Power-meter information, power demand, discharge, power-consumption coefficient, and lift for selected

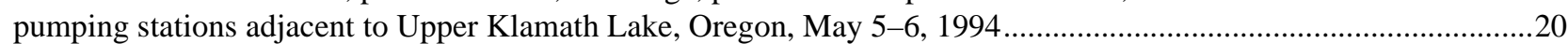

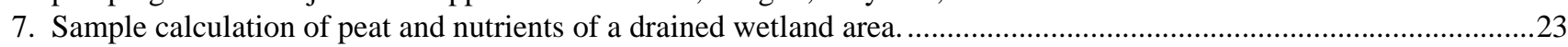

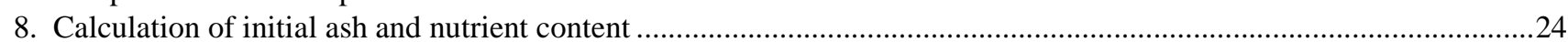

9. Summary of nutrient data from water-quality samples collected at selected pumping stations and flowing artesian wells adjacent to Upper Klamath Lake, Oregon, 1993-95. 
10. Concentration ranges of total nitrogen and total phosphorus from the Upper Klamath Lake area, Oregon 32

11. Instantaneous loads for pumping stations adjacent to Upper Klamath Lake, Oregon, May 5-6, 1994.

12. Estimated discharge, nutrient concentrations, and annual loads for flowing artesian wells adjacent to Upper Klamath Lake, Oregon, 1993-95. .

13. Parameters and estimates for estimation of annual loss and yield of total nitrogen and total phosphorus from drained areas using a first-order rate law .....

14. Initial, present day, and cumulative loss of peat and nutrients from drained wetlands by land use, expressed as mass and yield

\section{CONVERSION FACTORS AND VERTICAL DATUM}

\begin{tabular}{|c|c|c|}
\hline Multiply & By & To obtain \\
\hline \multicolumn{3}{|c|}{ Length } \\
\hline micrometer $(\mu \mathrm{m})$ & 0.00003937 & inch \\
\hline centimeter $(\mathrm{cm})$ & 0.3937 & inch \\
\hline inch (in.) & 2.54 & centimeter \\
\hline inch (in.) & 25.4 & millimeter \\
\hline foot $(\mathrm{ft})$ & 0.3048 & meter \\
\hline mile (mi) & 1.609 & kilometer \\
\hline \multicolumn{3}{|c|}{ Area } \\
\hline acre & 4,047 & square meter \\
\hline acre & 0.4047 & hectare \\
\hline square mile $\left(\mathrm{mi}^{2}\right)$ & 259.0 & hectare \\
\hline square mile $\left(\mathrm{mi}^{2}\right)$ & 2.590 & square kilometer \\
\hline \multicolumn{3}{|c|}{ Volume } \\
\hline milliliter (mL) & 0.06102 & cubic inch \\
\hline liter $(\mathrm{L})$ & 0.2642 & gallon \\
\hline cubic centimeter $\left(\mathrm{cm}^{3}\right)$ & 0.06102 & cubic inch \\
\hline cubic foot $\left(\mathrm{ft}^{3}\right)$ & 0.02832 & cubic meter \\
\hline acre-foot (acre-ft) & 1,233 & cubic meter \\
\hline \multicolumn{3}{|c|}{ Flow rate } \\
\hline cubic foot per second $\left(\mathrm{ft}^{3} / \mathrm{s}\right)$ & 0.02832 & cubic meter per second \\
\hline \multicolumn{3}{|c|}{ Mass } \\
\hline milligram (mg) & 0.00003527 & ounce, avoirdupois \\
\hline kilogram (kg) & 2.205 & pound avoirdupois \\
\hline pound, avoirdupois (lb) & 0.4536 & kilogram \\
\hline ton, short $(2,000 \mathrm{lb})$ & 0.9072 & megagram (metric ton) \\
\hline \multicolumn{3}{|c|}{ Density } \\
\hline \multicolumn{3}{|c|}{ Concentration, in water and soil } \\
\hline milligrams per liter $(\mathrm{mg} / \mathrm{L})$ & 1 & parts per million (ppm) \\
\hline milligrams per kilogram $(\mathrm{mg} / \mathrm{kg})$ & 1 & parts per million (ppm) \\
\hline \multicolumn{3}{|c|}{ Power } \\
\hline horsepower & 0.7457 & kilowatt $(\mathrm{kW})$ \\
\hline kilowatt (kW) & 1,000 & joule per second \\
\hline \multicolumn{3}{|c|}{ Energy } \\
\hline kilowatt-hour (kWh) & $3,600,000$ & joule \\
\hline \multicolumn{3}{|c|}{ Application rate } \\
\hline pounds per acre per year $[(\mathrm{lb} / \mathrm{acre}) / \mathrm{yr}]$ & 1.121 & kilograms per hectare per year \\
\hline
\end{tabular}

Temperature in degrees Celsius $\left({ }^{\circ} \mathrm{C}\right)$ may be converted to degrees Fahrenheit $\left({ }^{\circ} \mathrm{F}\right)$ as follows:

$$
{ }^{\circ} \mathrm{F}=\left(1.8 \times{ }^{\circ} \mathrm{C}\right)+32
$$

Temperature in degrees Fahrenheit $\left({ }^{\circ} \mathrm{F}\right)$ may be converted to degrees Celsius $\left({ }^{\circ} \mathrm{C}\right)$ as follows:

$$
{ }^{\circ} \mathrm{C}=\left({ }^{\circ} \mathrm{F}-32\right) / 1.8
$$

Sea level: In this report, "sea level" refers to the National Geodetic Vertical Datum of 1929 (NGVD of 1929) - a geodetic datum derived from a general adjustment of the first-order level nets of both the United States and Canada, formerly called Sea Level Datum of 1929. 


\section{DEFINITION OF TERMS}

Aerobic. Pertaining to or caused by the presence of oxygen.

Algal bloom. The rapid proliferation of passively floating, simple plant life, such as blue-green algae, in and on a body of water.

Alluvial. Pertaining to recent clastic deposits resulting from sediment transported by rivers.

Anaerobic. Pertaining to or caused by the absence of oxygen.

Aquifer. A unit of rocks or unconsolidated earth materials with sufficient permeability to yield water in a usable quantity to a well or spring.

Artesian. Ground water under pressure in an aquifer confined by less permeable rocks. If the aquifer is tapped by a well, the ground water will rise above the top of the aquifer and, under sufficient pressure, may rise above the land surface, creating a flowing artesian well.

Bulk density. Dry-matter mass per unit volume of in-situ material.

Caldera. A volcanic depression or crater generally circular in form with a diameter many times that of the enclosed volcanic vents. Can be formed by collapse, explosion, or erosion.

Clastic. Consisting of fragments of rocks that have been individually moved from their places of origin.

Content. A concentration generally expressed as a proportion of mass or volume.

Diatomaceous earth. See Diatomite.

Diatomite. A friable, light-colored sediment or sedimentary rock of low density, consisting of nearly pure silica composed principally from diatoms. Dry diatomite is normally white. Other colors are due to included sediment or organic impurities.

Diatom. Microscopic single-celled plant growing in marine or fresh water. (Diatoms are present today in Upper Klamath Lake.) Diatoms are a type of alga that secretes siliceous shell-like frustules in a great variety of forms that can accumulate in sediments in enormous numbers.

Escarpment. A long cliff or steep slope separating two comparatively level or more gently sloping surfaces and resulting from erosion or faulting.

Eutrophic. Applied to a highly productive body of water rich in dissolved plant nutrients. The decay of the organic matter produced may lead to the depletion of oxygen.

Fluvial. Pertaining to, produced by, or formed in a river.

Graben. A depressed segment of the earth's crust bounded on at least two sides by faults.

Hemic peat. See Peat, hemic.

Holocene. The period of time since the last ice age, about 10,000 years ago.

Inorganic. Containing no carbon; matter other than plant or animal.
Lacustrine. Pertaining to, produced by, or formed in a lake.

Muck. A soft, wet, organic-rich mud.

Nutrient. Any inorganic or organic compound needed to sustain plant or animal life.

Organic. Containing carbon, but possibly also containing other elements.

Peat. Partly decayed vegetable matter, inorganic minerals, and water in varying proportions (Cameron, 1973, p. 505).

Peat, hemic. The moderately decomposed peat. Generally reddish brown to medium brown but turns dark brown upon exposure to air. It consists predominantly of plant particles having diameters between about 0.01 and 0.1 inches; they are fragments of roots, stems, leaves, wood, bark, or seeds. Freshwater and saltwater marshes produce hemic peat from sedges, rushes, and grasses (Cameron and others, 1989, p. 110-111).

Peat, sapric. The most decomposed peat. Fine grained, generally dark brown to black, and, under compression, retains moisture and deforms as a paste. Although plant remains are basically unidentifiable in hand specimens, pollen and microscopic studies show that sapric peat is generally derived from small and easily decomposed algal and herbaceous aquatic plants of ponds and marshes (Cameron and others, 1989, p. 110).

Pleistocene. The period of time between the beginning of extensive glaciation about 1.6 millions years ago and the last ice age about 10,000 years ago.

Pluvial lake. A lake formed during a period of increased rainfall.

Quaternary. The period of time since the beginning of extensive glaciation about 1.6 millions years ago, and which can be further subdivided into the Pleistocene and the Holocene.

Riparian. Pertaining to the banks of a body of water.

Sapric peat. See Peat, sapric.

Subsidence. The gradual downward settling or sinking of the Earth's surface with little or no horizontal motion.

Theissen polygon. A polygon resulting from a method of interpolating between specific points. Theissen polygons are constructed by connecting the perpendicular bisectors of the lines connecting adjacent data points. The entire Theissen polygon is assumed to be represented by the data point contained in the polygon.

Total nitrogen. The sum of ammonia plus organic nitrogen in unfiltered water or soil samples and nitrite-plusnitrate nitrogen in filtered water or soil samples.

Total phosphorus. Phosphorus in unfiltered water or in soil samples following acid digestion.

Wetlands. In general terms, lands where saturation with water is the dominant factor determining the nature of soil development and the types of plant and animal communities living in the soil and on its surface (Cowardin and others, 1979, p. 3).

Yield. The mass of a constituent per area. 


\section{ACKNOWLEDGMENTS}

The authors would like to thank Ron Cameron, a U.S. Geological Survey volunteer, for his expertise and tireless efforts during the collection of soil samples. We are grateful to the many property owners and their staffs; members of the Bureau of Reclamation, Bureau of Land Management, and the U.S. Fish and Wildlife Service; and the many citizens of Klamath County who cooperated and assisted in this investigation. Frank Packard (U.S. Geological Survey) provided guidance and encouragement throughout the study. Jon House, Charlie Collins, Jim Poole, and Don Anderson (U.S. Geological Survey) assisted in the collection of field data. Jacob Kann (the Klamath Tribes) contributed through his knowledge of the lake and the surrounding areas. Finally, the late Cornelia Cameron (U.S. Geological Survey) is gratefully acknowledged for her assistance in the development of the conceptualization and recognition of the significance of the decomposition of peat soils. 


\title{
Nitrogen and Phosphorus Loading from Drained Wetlands Adjacent to Upper Klamath and Agency Lakes, Oregon
}

\author{
By Daniel T. Snyder and Jennifer L. Morace
}

\section{ABSTRACT}

Upper Klamath Lake and the connecting Agency Lake constitute a large, shallow lake in south-central Oregon that the historical record indicates has likely been eutrophic since its discovery by non-Native Americans. In recent decades, however, the lake has had annual occurrences of near-monoculture blooms of the bluegreen alga Aphanizomenon flos-aquae that are thought to be a result of accelerated eutrophication. In 1988, two sucker species endemic to the lake, the Lost River sucker (Deltistes luxatus) and the shortnose sucker (Chasmistes brevirostris), were listed as endangered by the U.S. Fish and Wildlife Service, and it has been proposed that their decline is due to the poor water quality associated with extremely long and productive algal blooms. It has also been proposed that the effluent drained from wetlands has contributed to accelerated eutrophication (Bortleson and Fretwell, 1993).

Since the turn of century, most of the wetlands adjacent to Upper Klamath Lake have been drained for agriculture - cultivation of crops and grazing of cattle. Wetland areas were reclaimed from the lake by building dikes to isolate them from the lake, constructing a series of drainage ditches, and installing pumps to drain the water and maintain a lowered water table. A consequence of lowering the water table is the increased ability of air and oxygenated water to move through the subsurface and facilitate the rapid aerobic decomposition of the peat soils. Nutrients, nitrogen and phosphorus, are then liberated, leach into adjacent ditches, and are subsequently pumped to the lake or its tributaries. The rate of peat decomposition may be related to the time since drainage and the type of agricultural land use. On lands cultivated for crops, farming practices, such as disking and furrowing, could enhance the movement of air and oxygenated water, resulting in rapid rate of decomposition. In contrast, on grazed lands, the compaction of soils by cattle probably inhibits the movement of air and oxygenated water and results in a slower rate of decomposition relative to drained wetlands used for the cultivation of crops.

This report presents the results of a cooperative study between the U.S. Geological Survey and the Bureau of Reclamation whose overall objective was to determine the nutrient loading to Upper Klamath Lake from adjacent drained wetlands. Nutrient loading from drained wetlands was estimated using two independent techniques. The first method involved the measurement of the quantity and quality of water discharged by pumps draining the wetlands. The second method was used to estimate the initial (before drainage) and present-day nutrient mass of the organic soils within the drained wetlands and to calculate the change (or loss) in nutrient mass.

In an effort to estimate the nutrient contributions from the water pumped off selected drained wetlands adjacent to Upper Klamath Lake, annual loads and yields of total nitrogen and total phosphorus were estimated from concentration data and the volume of water pumped during the water year. In general, there was little variation among sites or among years in the annual total nitrogen (median load of about 18 tons per year and median yield of about 8 pounds per acre per year) or the annual total phosphorus (median load of about 3 tons per year and median yield of about 2 pounds per acre per year) contributions. The sum of the annual loads of nitrogen and phosphorus calculated for each of the pumping stations in 1995 was 80 tons per year and 15 tons per year, respectively. 
In 1995, soil-coring activities were undertaken to ascertain the nature and extent of the organic soils in the drained and undrained wetlands. The present-day nutrient mass was calculated for each drained wetland using the nutrient content (concentration) and the present-day peat mass. The initial nutrient mass prior to drainage was estimated for each drained wetland by using the initial nutrient content (assumed to be equal to the nutrient content of the undrained wetlands) and the initial peat mass as determined using the amount of accumulated decomposition residue. The cumulative loss of nutrient mass since drainage was calculated as the change between initial and present-day nutrient mass for each drained area.

The cumulative yield of total nitrogen and total phosphorus loss from the organic soils of individual wetlands since drainage ranged from 3,000 to 70,000 pounds per acre and from 0 to 1,300 pounds per acre, respectively. For all the drained wetlands sampled, the cumulative nitrogen and phosphorus loss since drainage totaled 250,000 tons and 4,300 tons, respectively. This represents about 30 percent and 22 percent of the mass of nitrogen and phosphorus, respectively, that initially existed in the organic soils. The loss of nutrients from the drained wetlands is considered to be a maximum estimate of the possible contribution of nutrients to Upper Klamath Lake from the peat soils of the drained wetlands sampled. However, not all the nutrients released by the soils are discharged to the lake. Nutrients lost from the peat soils of the drained wetlands may have been taken up by crops and harvested or consumed by grazing cattle. In addition, nitrogen can be lost to the atmosphere by denitrification and the volatilization of ammonia; phosphorus may be bound to adjacent soil layers by adsorption.

The annual nutrient loss for the period 1994-95 was calculated using a first-order rate law to describe nutrient loss since drainage began. For individual drained wetlands, the yield of nitrogen and phosphorus lost from the organic soils for the period 1994-95 ranged from 27 to 540 pounds per acre per year and from 0 to
15 pounds per acre per year, respectively. The total mass of nitrogen and phosphorus loss during this period was 3,000 tons per year and 60 tons per year, respectively, for all drained wetlands that were sampled. The yield and mass of nutrient loss determined in this fashion reflect what might be expected on the basis of time-averaged or longterm contributions of nutrients to the lake and do not reflect the specific conditions existing during the period 1994-95.

The results of this study could be useful in helping to prioritize which drained wetlands may provide the greatest benefits with regard to reducing nutrient loads to the lake if restoration or landuse modifications are instituted. Recent acquisition and planned restoration of drained wetland areas at the Wood River and Williamson River North properties may produce significant reduction in the quantity of nutrients released by the decomposition of peat soils of these areas. If the water table rises to predrainage levels, the peats soils may become inundated most of the year, resulting in the continued long-term storage of nutrients within the peat soils by reducing aerobic decomposition. The maximum benefit, in terms of decreasing potential nutrient loss due to peat decomposition, could be the reduction of total nitrogen and total phosphorus loss to about onehalf that of the 1994-95 annual loss estimated for all the drained wetlands sampled for this study.

\section{INTRODUCTION}

Upper Klamath Lake and the connecting Agency Lake constitute a large, shallow lake in south-central Oregon (fig. 1). For purposes of subsequent discussion, the name "Upper Klamath Lake" will be understood to include Agency Lake. The historical record indicates that the lake has likely been eutrophic since its discovery by non-Native Americans (Bortleson and Fretwell, 1993). In recent decades, however, the lake has had annual occurrences of near-monocultural blooms of the blue-green alga Aphanizomenon flos-aquae that are thought to be a result of accelerated eutrophication. In 1988, two sucker species endemic to the lake, the Lost River sucker (Deltistes luxatus) and the shortnose sucker (Chasmistes brevirostris), 


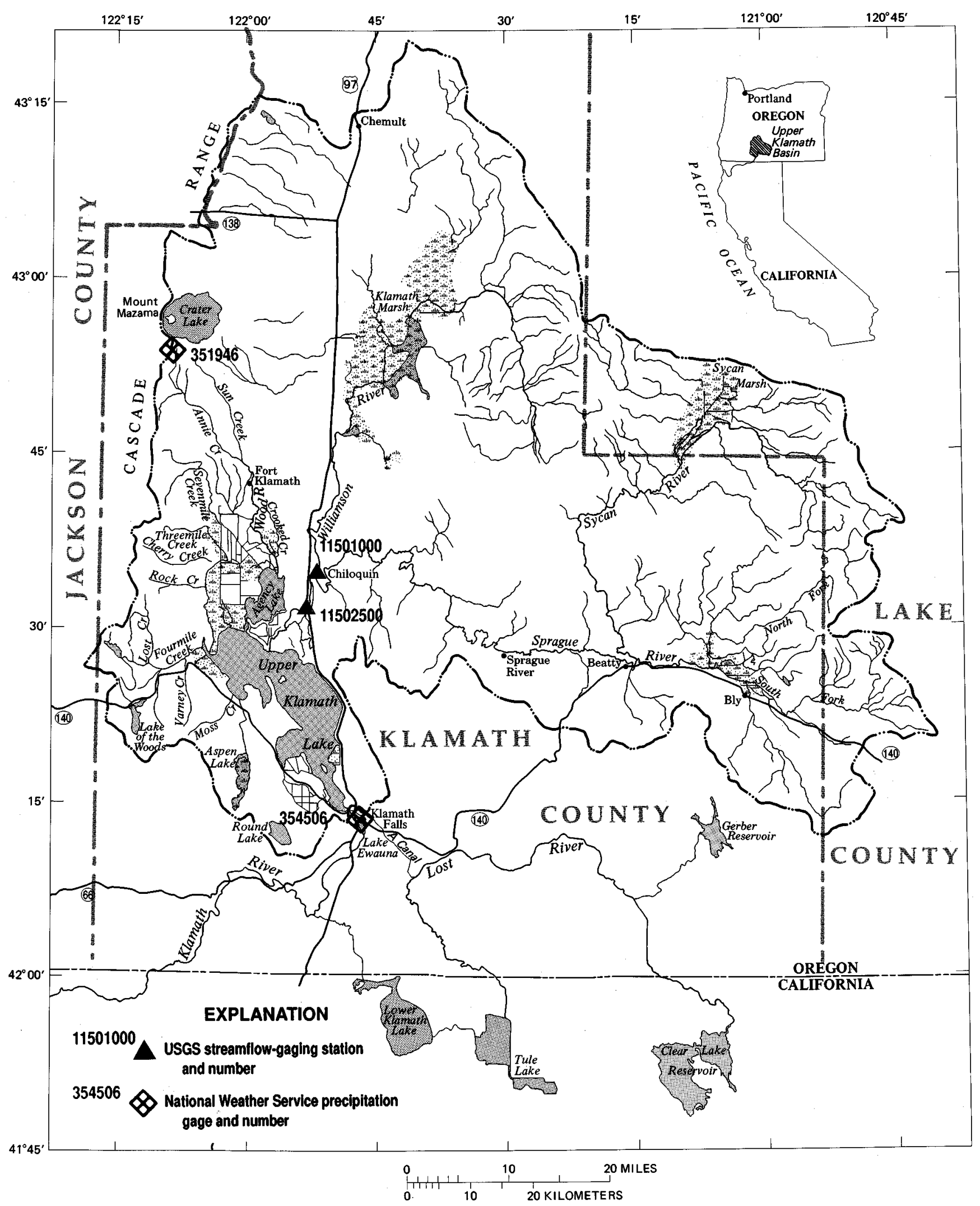

Figure 1. Upper Klamath Lake Basin and vicinity. 
were listed as endangered by the U.S. Fish and Wildlife Service (Federal Register, 1988), and it has been proposed that their decline is due to the poor water quality associated with extremely long and productive algal blooms. It has also been proposed that the effluent from wetlands drained for agriculture has contributed to worsening water quality through an increase in nitrogen and phosphorus released by the accelerated decomposition of peat soils exposed to air or oxygenated water (Bortleson and Fretwell, 1993).

The U.S. Geological Survey (USGS), in cooperation with the Bureau of Reclamation, developed a study in 1991 to assess nutrient loading and waterquality characteristics of Upper Klamath Lake. Three reports have already been published as part of this study. Brownell and Rinallo (1995) prepared an extensive bibliography of water-related research in the Upper Klamath Basin. Laenen and LeTourneau (1996) estimated the wind-induced resuspension of bed sediment during periods of low lake elevation. Wood and others (1996) studied the relation between selected water-quality variables and lake level. The following is a report on nutrient loading from drained wetlands adjacent to Upper Klamath Lake.

\section{Purpose}

The purpose of this report is to describe the nitrogen and phosphorus loading to Upper Klamath Lake from adjacent drained wetlands. A brief description of the soils in the undrained and drained wetlands is included to provide a basis on which the estimates of nutrient loading were made. Implications of nutrient loading from regional ground-water discharge were considered, but estimates of this component of loading were not within the scope of the study. Results from this report will be of use to resource managers. Possible uses of the information are to:

- Quantify the contribution of nutrients from drained wetlands to Upper Klamath Lake relative to other sources of nutrients to the lake.

- Provide sufficient information to guide efforts to reduce nutrient loading to Upper Klamath Lake by indicating whether modifying present-day land-use practices or restoring the drained wetlands will provide benefits in terms of reducing nutrient loads to the lake.

- Identify which drained wetlands may provide the greatest benefits if restoration or land-use modifications are instituted.
- Provide baseline data on conditions within the drained wetlands for later comparisons to monitor the effectiveness of land-use modifications or restoration activities.

- Provide insight on the possible effects on water quality resulting from rotating between flooded wetlands and agricultural cropland as has been proposed for parts of the nearby Tule and Lower Klamath Lakes National Wildlife Refuges.

\section{Approach}

The study involved two phases of activity: (1) water samples and discharge measurements were collected to determine the concentration and quantity of discharge from pumps draining selected wetlands used for agriculture, and were subsequently used to calculate nutrient loads to Upper Klamath Lake; and (2) soil samples were collected from drained wetlands, analyzed, and compared with samples collected from undrained wetlands to estimate the loss of nutrients from the decomposition of organic soils due to the exposure to oxygen after drainage.

\section{Previous Work}

Several studies have focused on the eutrophication problems in Upper Klamath Lake. Phinney and Peek (1961) stated that the source of nutrient-rich water entering Upper Klamath Lake was a result of the natural drainage from undrained wetlands and the drainage water from wetlands drained for agriculture and was a consequence of leachate from the organic part of the wetland soils. However, they made no attempt to quantify the nutrient load or to describe the relative contributions of undrained versus drained wetlands to the nutrient load to the lake.

Miller and Tash (1967) constructed a preliminary nutrient budget for Upper Klamath Lake for the period of March 1965 through April 1966 and calculated the nutrient load from springs, streams, rivers, canals, and agricultural drainage. This represented a 14-month budget, which cannot easily be adjusted to an annual budget due to the lack of monthly data and to the uneven distribution of water volumes and nutrient concentrations over the course of a year. In their budget, agricultural drainage accounted for only 5 percent of the inflow of water but contributed 20 percent of the incoming nitrogen load and 
26 percent of the incoming phosphorus load to the lake. Miller and Tash (1967) did not discuss the cause(s) of the high nutrient concentrations in agricultural drainage. Since 1966, the area of wetlands drained for agriculture adjacent to Upper Klamath Lake has increased by about 30 percent (7,200 acres).

The U.S. Army Corps of Engineers (1982) collected additional water-quality and discharge data to supplement the work of Miller and Tash (1967). However, no new data for agricultural drainage were collected and the major conclusions from Miller and Tash remained unchanged.

A later study of Upper Klamath Lake prepared by the Klamath Consulting Service (1983) discussed restoration alternatives designed to reduce the eutrophication-induced problems in the lake. They concluded that "human contribution to the problem is minimal" and that the eutrophication of Upper Klamath Lake was a result of "naturally occurring high nutrient load." Water-quality data collected during this study did not include direct measurements of agricultural or wetland drainages.

Additional studies of the process and consequences of eutrophication of Upper Klamath Lake are presented in the Bureau of Reclamation's 1991 and 1992 annual reports on environmental research in the Klamath Basin, Oregon, edited by Campbell (1993a, 1993b). These reports describe research and preliminary results from studies that are or were in progress and as yet contain little interpretation with regard to nutrient loading from drained or undrained wetlands. Included are progress reports of a study that is assessing the importance of drained and undrained wetlands on water quality of Upper Klamath Lake by evaluating the quality of water discharged from these areas (Sartoris and Sisneros, 1993; Sartoris and others, 1993). Also of interest in the 1991 annual report is the work by Carlson (1993) that documents the change in land use and area of wetlands from 1940 to 1989. Carlson estimated that about 73,000 acres of undrained wetlands existed adjacent to Upper Klamath Lake and in portions of the Wood River Valley in 1940. About 20,000 acres of the wetlands adjacent to the lake were subsequently drained for agriculture by 1989.

Gearheart and others (1995a; 1995b; 1995c) examined watershed strategies for improving the water quality of Upper Klamath Lake. Their approach included a review of written literature and an assessment of research currently in progress. A steady-state lake model was developed using previously available data to show the relationship between loading rates, settling rates, and annual average in-lake total phosphorus concentrations. The effects of several management practices identified for different land-use activities were evaluated with regard to total cost and time to reach various in-lake total phosphorus levels. The study concluded that the loss of wetlands in the Upper Klamath Lake watershed has significantly changed the hydrology, biochemistry, and related ecology of the area and that source reduction, through the use of best management practices, is the only economic and technically effective strategy for managing the lake for sensitive fish species (Gearheart and others, 1995b). However, although the importance of agricultural drainage and the decomposition of peat soils is mentioned, these factors were not quantified due to the lack of data.

\section{Background and Description of the Study Area}

\section{Physiography and Hydrography}

Upper Klamath Lake is in a large, flat valley adjacent to the eastern slopes of the Cascade Range in south-central Oregon (fig. 1). It is the largest lake (by area) wholly within Oregon, having a surface area of about $140 \mathrm{mi}^{2}$ (square miles) at maximum lakesurface elevation, a length of about $25 \mathrm{mi}$ (miles), and a width ranging from 2.5 to $12.5 \mathrm{mi}$. (Representative physical characteristics of the lake are summarized in table 1.) Despite its large size, the lake is shallow and has a mean summer depth of about $8 \mathrm{ft}$ (feet) and a maximum depth of about $58 \mathrm{ft}$ (U.S. Army Corp of Engineers, 1979, 1982).

The drainage area for Upper Klamath Lake is about $3,800 \mathrm{mi}^{2}$. The principal tributaries to the lake are the Williamson and Wood Rivers (fig. 1). The Williamson River is the largest, with much of its flow derived from the Sprague River. In addition to streams, spring flow and ground-water seepage provide continuous inflow to the lake throughout the year (Illian, 1970). Upper Klamath Lake is drained at the southern end by the Link River, which flows through a short reach and enters Lake Ewauna at Klamath Falls. The headwaters of the Klamath River proper are about 1 mi south of Klamath Falls where Lake Ewauna flows into the Klamath River. Link River Dam on the Link River regulates the flow from Upper Klamath Lake. Since 1919, the operation of Link River Dam 
Table 1. Physical characteristics of Upper Klamath and Agency Lakes, Oregon

[Source of data: U.S. Army Corp of Engineers (1979, p. 43) $\mathrm{mi}^{2}$, square miles; ft, feet; acre-ft, acre-feet]

\begin{tabular}{ll}
\hline $\begin{array}{l}\text { Drainage area } \\
\text { Lake surface elevation }\end{array}$ & $3,800 \mathrm{mi}^{2}$ \\
${ }^{*}$ Minimum & \\
Mean summer & $4,137.0 \mathrm{ft}$ \\
Maximum & $4,141.3 \mathrm{ft}$ \\
Surface area & \\
At minimum lake surface elevation & 60,000 acres \\
At mean summer lake surface elevation & 77,500 acres \\
At maximum lake surface elevation & 90,000 acres \\
Volume & \\
At minimum lake surface elevation & 350,000 acre- $\mathrm{ft}$ \\
At mean summer lake surface elevation & 620,000 acre- $\mathrm{ft}$ \\
At maximum lake surface elevation & 875,000 acre-ft \\
Average depth & \\
At minimum lake surface elevation & $5.8 \mathrm{ft}$ \\
At mean summer lake surface elevation & $8.0 \mathrm{ft}$ \\
At maximum lake surface elevation & $9.7 \mathrm{ft}$ \\
\hline
\end{tabular}

* In 1994, the lake-surface elevation was 4,136.8 ft (Mark Buettner, Bureau of Reclamation, written commun., 1996).

has allowed seasonal lake-stage elevations to be maintained at levels either higher or lower than pre-dam levels. A rock sill was cut away to allow lake levels to be drawn about $3 \mathrm{ft}$ lower than historical levels. Since the dam was built, the lake level normally has been maintained between 4,137 and $4,143 \mathrm{ft}$.

\section{Climate}

The semiarid climate in the Upper Klamath Basin is characterized by hot, dry summers and moderately wet winters with moderate to low temperatures. Precipitation is variable throughout the basin owing to the diverse topography of the area and a rain shadow created by the Cascade Range. From 1961 to 1990 , mean annual precipitation at the Klamath Falls Airport was 13.5 inches (standard deviation is about 2.8 inches). During this study, precipitation at the Klamath Falls Airport in Klamath Falls was 15.8 inches, 9.8 inches, and 18.3 inches for 1993 , 1994, and 1995, respectively. About 72 percent of the precipitation occurs in the 6-month period from October through March. Snowfall averages about 35 inches per year. The mean annual temperature at Klamath Falls Airport from 1961 to 1990 was $48^{\circ} \mathrm{F}$ (degrees Fahrenheit), the mean maximum temperature during July and August was $84^{\circ} \mathrm{F}$, and the mean minimum temperature during December and January was $21^{\circ} \mathrm{F}$ (National Oceanic and Atmospheric Administration, 1994, 1995, 1996).

\section{Geology}

The north-northwest trending Klamath Basin corresponds, in part, to a down-faulted crustal block, which is 6-9 mi wide (Sherrod, 1993). It is known as the Klamath graben and extends north toward Crater Lake in the Cascade Range and is bounded by high, steep escarpments, especially along the eastern rim. As much as 6,600 ft of unconsolidated sediment fills the graben. Rocks in the area are predominantly of volcanic origin, consisting of unconsolidated or consolidated volcanic materials or unconsolidated sediments largely derived from volcanic rocks (Leonard and Harris, 1974).

Parts of the Upper Klamath Lake drainage were heavily glaciated during the Pleistocene. None of these glaciers reached as far as Upper Klamath Lake, but glacial runoff flowed into the basin (Adam and others, 1994). During this time, a large pluvial lake (Lake Modoc) covered much of the basin floor. Lake Modoc consisted of several connected arms having an overall length of about $75 \mathrm{mi}$ that extended from Fort Klamath in the north to south of Tule Lake in California (Dicken, 1980). At maximum extent, the lake covered an area of about $1,100 \mathrm{mi}^{2}$ and had an elevation of about $4,240 \mathrm{ft}$, equivalent to about $100 \mathrm{ft}$ above the present-day Upper Klamath Lake. Large quantities of ash and pumice as well as accumulations of diatoms and peat were deposited in the basin. The thickness of these sediments reaches hundreds of feet in some areas (Dicken and Dicken, 1985). At the end of the Pleistocene, perhaps 10,000 years ago, Lake Modoc began to shrink, forming several smaller lakes-Upper Klamath Lake in Oregon and Lower Klamath and Tule Lakes in California (Dicken, 1980).

After the lowering of Lake Modoc, wetlands became established in many areas of the lake. Lake sediments consist of Quaternary-age deposits of lacustrine diatomaceous clays and silts; alluvial floodplain deposits of volcanic ash-rich clays, silts, and sands; and deposits of peat and other organic materials (Cahoon, 1985; Bureau of Land Management, 1995).

About 6,900 years ago, a massive eruption occurred from what is now referred to as Mount Mazama at the northern end of the Upper Klamath Lake drainage (Bacon and Lanphere, 1990). Mount Mazama collapsed during this climactic eruption, forming the caldera now occupied in part by Crater Lake and generating a pumice and ash deposit over an enormous area of western North America (Geitgey, 1992). Owing to prevailing winds, most of the pumice 
and ash was deposited to the northwest of Mount Mazama. The thickness of air-fall pumice is presently about 6 inches on the upland areas immediately north of Agency Lake and decreases rapidly southward (Walker, 1951; Williams, 1965). The area of the Wood River Valley extending southward into Upper Klamath Lake contains washed pumice and ash resulting from the deposition and movement of volcanic materials moved down from Mount Mazama along its southwestern drainages (Williams, 1965). Pumice and ash ejected from Mount Mazama during the climactic eruption and possibly during earlier Holocene eruptions underlie the present-day wetlands in many areas (Smith, 1988). These deposits may represent air-fall and flow pumice, or may, in part, have been reworked and transported by water.

Cores drilled in the wetlands near the southwestern part of Upper Klamath Lake reflect the longterm and recent history of Upper Klamath Lake. A 166-foot core obtained by Adam and others (1994) from Wocus Marsh has alternating intervals of highly organic and inorganic sediments that were deposited over a period of perhaps the last 1 million years. Peat deposits are present to a depth of about $85 \mathrm{ft}$ and may be nearly 400,000 years old. In a core from Caledonia Marsh, lacustrine clays, which are present in the section below about $17 \mathrm{ft}$, are in sharp contact with overlying organic-rich clay deposited in the marsh. On the basis of estimated sedimentation rates, the change happened about 11,000 years ago near the end of colder climatic conditions at the end of the Wisconsin Glaciation (or most recent glaciation) and subsequent lowering of Lake Modoc (Rosenbaum and others, 1995). The lacustrine clays resulted from the past deep-water environment of Lake Modoc and the organic-rich clays represent the more recent shallower environments of Upper Klamath Lake. Volcanic materials resulting from the deposition of ash from Mount Mazama were observed at about $10.5 \mathrm{ft}$ in the Caledonia Marsh core.

\section{Regional Ground-Water Flow}

The surrounding mountains are recharge areas for the regional ground-water flow system from which ground water moves toward the lowlands. Ground water is discharged by upward seepage in all the lowland areas, by the many springs that contribute to streamflow, by evapotranspiration in the prominent wetlands around Upper Klamath Lake, and by seepage to Upper Klamath Lake (Illian, 1970; Leonard and
Harris, 1974). Strong upward flow gradients are evident from the many flowing artesian wells adjacent to the lake, especially in the lower Wood River Valley.

\section{Soils and Vegetation}

The soils of the wetlands adjacent to Upper Klamath Lake formed from the alluvial, lacustrine, and organic materials that were deposited in Upper Klamath Lake. The alluvial sediments consist of clays, silts, and sands derived from the volcanic rocks that dominate the area and have been eroded and transported by tributaries to the lake. The most abundant lacustrine sediments now accumulating in Upper Klamath Lake are diatomaceous and organic materials. Diatoms are growing today in Upper Klamath Lake, resulting in the deposition of diatomaceous clays and silts throughout the lake (Peterson and McIntyre, 1970; Bureau of Land Management, 1995). The organic material, in the form of peat, developed over thousands of years from the annual growth, death, and decomposition of wetland vegetation. Volcanic ash, sedimentary materials, and diatomaceous material are layered within the peat (Sorenson and Schwarzbach, 1991).

Vegetation associated with the wetland areas is a typical sedge-reed community, including bulrush, cattails, and wocus lily (Cahoon, 1985; Johnson and others, 1985).

\section{Peat Formation and Decomposition}

The peat material underlying the drained and undrained wetlands adjacent to Upper Klamath Lake appear to be of the reed-sedge type (Peterson and McIntyre, 1970). The following discussion of the cycle of peat development for a reed-sedge type of vegetation is adapted from descriptions by Cameron (1970, 1973, 1975). The normal sequence in these deposits of the filled-basin type consists of a basal inorganic clay grading upward to organic clay containing diatoms and algal debris overlain by peaty clay, clayey peat, and finally reed-sedge peat. This stratigraphy records a history of changing environments during which the pond, receiving only inorganic clay at first, continues to fill with clay and floating plants, such as algae and pond weeds, until the water becomes shallow enough to support growth of rooted plants such as pond lilies and bulrushes. As vegetative remains accumulate, water of the vestigial pond is eventually replaced by marsh grass, reeds, and sedges. 
Boundaries are gradational between stratigraphic units belonging to the same cycle. Discontinuities mark the interruption of one cycle and the beginning of another. The discontinuities can also consist of deposits of clastic debris and beds of peat with clay, sand, or silt between the beds of peat. The clastic debris represent episodes of ponding or flooding.

Peat forms when the rate of accumulation of plant material exceeds the rate of decay by bacterial and chemical action. Plant material is added primarily at the surface, where it may fall into water or upon water-saturated soil and become buried. Decay, on the other hand, can take place not only at the surface, but throughout the peat thickness. However, the rate of decay generally is highest in the unsaturated surface layers and lowest in the saturated zones of peat (Cameron, 1989). Compared to unsaturated organic deposits, a deposit saturated with water is relatively free from dissolved oxygen. Aerobic microbial communities decay vegetable matter more rapidly and completely than anaerobic microbial communities which cannot degrade many organic constituents (Broadbent, 1960). Peat may continue to exist indefinitely unless the land is drained and decomposition begins (Cameron, 1973).

Peat starts to form as soon as plants die and a series of changes begin that are generally faster at first, becoming slower as time goes on. These changes are called decay, decomposition, breakdown, or humification. The processes encompassed by them are (1) loss of organic matter, as a gas or as soluble breakdown products, as a result of leaching and attack by microorganisms; (2) loss of physical structure; and (3) change of chemical state, that is, the production of new types of molecules by microorganisms (Cameron, 1989). For the purposes of this report, the term "decomposition" will be used to describe all of these processes. Peat decomposition is accompanied by loss of water, carbon dioxide, and other volatile products, and results in concentrating the inorganic fraction (Brown and Farnham, 1976). In soils having a high content of organic materials, especially acid peat soils (low pH), the essential nutrients (calcium, potassium, nitrogen, and phosphorus) are mobile and easy to leach out because at lower $\mathrm{pH}$ such soils have a lower cation exchange capacity (Goode and others, 1977).

Climate, topography, and changes in water table depth are the chief factors governing the formation and preservation of peat deposits (Cameron, 1989).
Microbial activity increases with increasing temperature, thus inducing greater rates of decomposition. The topography governs the type of incoming waters which provide nutrients for the formation of the peat deposit and may influence the position of the water table. Fluctuating water tables within the deposit can permit oxygenation of the organic material, thereby allowing aerobic microbes to decompose the plant fibers. Fluctuation of oxygenated water is generally greatest near the surface and near water bodies where the water table seasonally rises and falls. Where water tables remain high, peat accumulates faster than it decays (Cameron and others, 1989). Other factors that can influence the preservation of peat are land use, plant cover, and $\mathrm{pH}$, high values of which can promote microbial activity (Eggelsmann, 1976; Cameron, 1989).

\section{Peat Properties}

An estimate of the degree of decomposition is one of the most useful qualitative properties for the description and categorization of peat. Three major categories were used to describe the peat within the soils around Upper Klamath Lake: hemic peat, hemic/ sapric peat, and sapric peat. Hemic peat is undecomposed to moderately decomposed peat, sapric peat is the most decomposed peat, and hemic/sapric peat is intermediate to hemic and sapric peat.

The color of peat material is representative of the degree of decomposition of the peat (Cameron, 1973, 1975). Hemic peat that is newly exposed or has been well protected from the air is generally light yellow or brown. Partially decomposed hemic or hemic/sapric peat is brown to dark brown. Well-decomposed sapric peat is black. The appearance of alternating colored narrow bands of dark decomposed and light undecomposed soil materials may be due to microbiological differences which are, in turn, probably connected with the position and fluctuation of the water table (Cameron, 1970, 1989).

Fiber content refers to the proportion of stem, leaf, or other plant fragments that make up peat. The proportion of fiber is generally closely linked to the extent of decomposition (Cameron, 1975, 1989). As decomposition proceeds, the size of organic particles or fibers decreases (Boelter, 1969).

Ash consists of the inorganic solids remaining after a test portion of dry peat has been heated to a temperature of generally $450^{\circ}-550^{\circ} \mathrm{C}$ (degrees Celsius) to remove the organic matter (Cameron, 1973). 
Ash content is a concentration and is generally expressed in weight percent on the dry basis. The inorganic components of peat include minerals from the substrate and elements absorbed by plants from ground water or surface water, including incoming floodwaters and runoff from surrounding uplands or the drainage basin. Also, minerals are introduced as suspended detritus, precipitated from solutions, or deposited by wind, such as dust or volcanic ash (Brown and Farnham, 1976; Cameron and others, 1989).

Bulk density (dry-matter mass per unit volume of in-situ peat) is commonly used as an indicator of the degree of decomposition (Brown and others, 1984; McDonnell and Farrell, 1984; Mulqueen, 1986). As decomposition proceeds, the size of organic particles or fibers decrease, allowing for greater compaction and higher bulk density (Boelter, 1969).

The $\mathrm{pH}$ of the peat materials influences microbial activity, decomposition, and the leaching of nutrients from the organic material. Strongly acid soils support a limited variety of microbes. In-situ $\mathrm{pH}$ of natural peat is normally acidic, although it ranges from 3.2 to 7.5 (Cameron, 1975).

\section{Drainage of Wetlands and Effects of Land Use}

Drainage of wetlands results in a lowering of the water table, which improves aeration of peat soils and enhances soil microbial activity, thereby accelerating the decomposition of organic matter (Maciak, 1972; Lee and Manoch, 1974; Lévesque and Mathur, 1979; Mathur and Farnham, 1985; Efimov and Lunina, 1988; Petukhova, 1988; Laine and others, 1992). The rate is dependent on climate, land use, and ground-water level (Efimov and Lunina, 1988; Petukhova, 1988).

Where the land use is agriculture, the type of agriculture is also an important factor with regard to the rate and extent of decomposition of organic soils. Decomposition is generally greater for tilled areas than for non-tilled areas such as grasslands or pasture (Eggelsmann, 1976; Lévesque and Mathur, 1979; Mathur and Farnham, 1985; Levanon and others, 1987; Petukhova, 1988; Voznjuk and others, 1988; Berglund, 1992; Bartels and Scheffer, 1996). Tillage breaks up the soil surface and enhances the movement of air and oxygenated water in the soil. Areas used for grazing are trampled by cattle, resulting in compaction of the surface soils, which inhibits the movement of air and oxygenated water into the subsurface and may slow the rate of decomposition of the organic materials (Schalitz and others, 1996). Adding soil amendments such as lime $\left[\mathrm{CaO}\right.$ or $\left.\mathrm{Ca}(\mathrm{OH})_{2}\right]$, to raise soil $\mathrm{pH}$, or nitrogen fertilizer can further accelerate the decomposition of organic soils (Kaunisto, 1976; Kuntze, 1984, 1992; Mathur and Farnham, 1985; Efimov and Lunina, 1988).

After drainage, the rate of decomposition of organic matter is high initially and declines exponentially with time. This has been observed in laboratory studies as well as in the field, where it also may be manifested by subsidence (Broadbent, 1960; Gallagher, 1978; Mathur and Farnham, 1985; Petukhova, 1988).

Organic materials undergo subsidence soon after drainage, primarily as the result of decomposition. Initially, subsidence occurs because of the lowered water table and subsequent loss of buoyancy as the underlying layers become compacted by the extra weight (Mulqueen, 1986). This is followed by continued subsidence from the decomposition of the organic materials (Stephens, 1956; Lynn and others, 1974). The maximum rate of subsidence occurs initially and decreases exponentially with time, as it is closely related to the rate of decomposition (Eggelsmann, 1976; Nesterenko, 1976). Factors affecting subsidence include depth of drainage, land use, wind erosion, loss by fire, mineralization, initial peat thickness, peat density, climatic conditions, and the amount of time since drainage began (Nesterenko, 1976; Berglund, 1992).

\section{Land and Water Use}

\section{Historical}

Land has been used for agriculture for more than 100 years in the region, possibly dating back to 1860 . The wetlands provided wild hay harvested for cattle, and the preferred location for cattle grazing was in and near the wetlands on the margins of the lakes (Akins, 1970). Beginning before 1900, dikes were built in the low-lying marshy areas to prevent flooding of the wetlands where farmers cut wild hay (Dicken and Dicken, 1985). Since then, large areas of the wetlands that surround Upper Klamath Lake have been diked, ditched, and drained for agricultural use. Much of the wetlands were converted to pasture for grazing of cattle, particularly at the northern end of the lake, where temperatures are cooler and less suitable for cultivated crops. Areas of higher ground on the central and southern shores of Upper Klamath Lake were commonly cultivated for crops such as cereal hay and potatoes. 
The drained wetlands have been incised by a series of deep interconnecting ditches and canals. To facilitate surface drying and agricultural usage, water that has accumulated from precipitation and surface runoff from adjacent slopes (especially during October through March), as well as irrigation and seepage of ground water, is seasonally or continually pumped from the canals and ditches to Upper Klamath Lake or its tributaries. At least 15 pumping stations situated around the lake drain the wetlands used for agriculture. Many of the drained wetlands were initially tilled to remove native vegetation and some of the drained wetlands were levelled to assist tillage.

\section{Present Day}

Presently, Upper Klamath Lake serves as a reservoir to provide water for agricultural use, electricalpower generation, recreational use, and extensive wildlife use. The area around the lake is an important agricultural area for crops and livestock. Farming in the area consists of row and field crops, including hay, barley, wheat, and potatoes. Pasture is used for grazing of livestock such as beef cattle, dairy cows, and sheep. Some of the drained wetland areas are used as pastures only during the spring and summer. Algae is harvested from the lake and at its outlet near the Link River and processed for sale as a health food product.

The Klamath Basin is a key area on the Pacific Flyway and a major resting place for migratory waterfowl, as well as a residence for a large variety of wildlife. Around Upper Klamath Lake are several areas where wetlands and parts of the lake have been set aside for wildlife. The Upper Klamath National Wildlife Refuge consists of two areas. A 13,800-acre area adjacent to the northwestern edge of Upper Klamath Lake and a 1,200-acre unit at Hanks Marsh on the eastern side of the lake. The State of Oregon has two wildlife refuges along Upper Klamath Lake-1,300 acres at the Shoalwater Bay Wildlife Area at the southern end of Shoalwater Bay and 370 acres at the Squaw Point Wildlife Area along the northern shore of Howard Bay. During fall and spring, nearly 1 million ducks, geese, swans and other birds migrating the Pacific Flyway flock to the wetland areas in and around the wildlife refuges in the Klamath Basin to rest and feed before continuing their journey. The area around Upper Klamath Lake also supports large concentrations of wetland birds such as pelicans, grebes, cormorants, egrets, and herons and provides important habitat for a number of introduced and native fish species, including the endangered shortnose and Lost River suckers.

The drained wetlands adjacent to Upper Klamath Lake have recently been the focus of efforts to improve water quality and fish habitat in Upper Klamath Lake. Between 1993 and 1996, about 8,000 acres, consisting predominantly of drained wetlands adjacent to Upper Klamath Lake, were acquired in separate acquisitions by the Bureau of Land Management (BLM) and the Nature Conservancy. The Wood River Property, consisting of about 3,200 acres, was purchased by the BLM with the intent of wetland restoration (Bureau of Land Management, 1995).

The Nature Conservancy purchased nearly 4,800 acres of the Williamson River North property, which will be managed in partnership with the Natural Resources Conservation Service for the purpose of wetland/riparian restoration directed to benefit the endangered Lost River and shortnose suckers $(\mathrm{CH} 2 \mathrm{M}$ Hill, 1996). The Bureau of Land Management (1995) has stated that it is possible that additional lands could be acquired in the same general area for the purpose of wetland restoration.

\section{METHODS}

Nutrient loads from the drained wetlands were estimated using two methods. The first method involved the collection of samples for the determination of water quality and estimation of the quantity of water pumped from the drained wetlands. The second method involved the description of soil cores and the collection and analysis of soil samples from the drained and undrained wetlands.

\section{Data Collection}

\section{Water Samples}

\section{Sampling}

Six pumping stations used to remove water from five drained wetland areas were sampled intermittently by the USGS from 1993 through 1995 (fig. 2). The sampling schedule was designed for samples to be collected approximately every 3 weeks; however, the pumps were not always operating when sampling was scheduled. Samples were collected in a 3-liter polyethylene bottle attached to a long handle (to facilitate collection). At four of the six pumping stations, the samples were collected from the discharge pipes. 


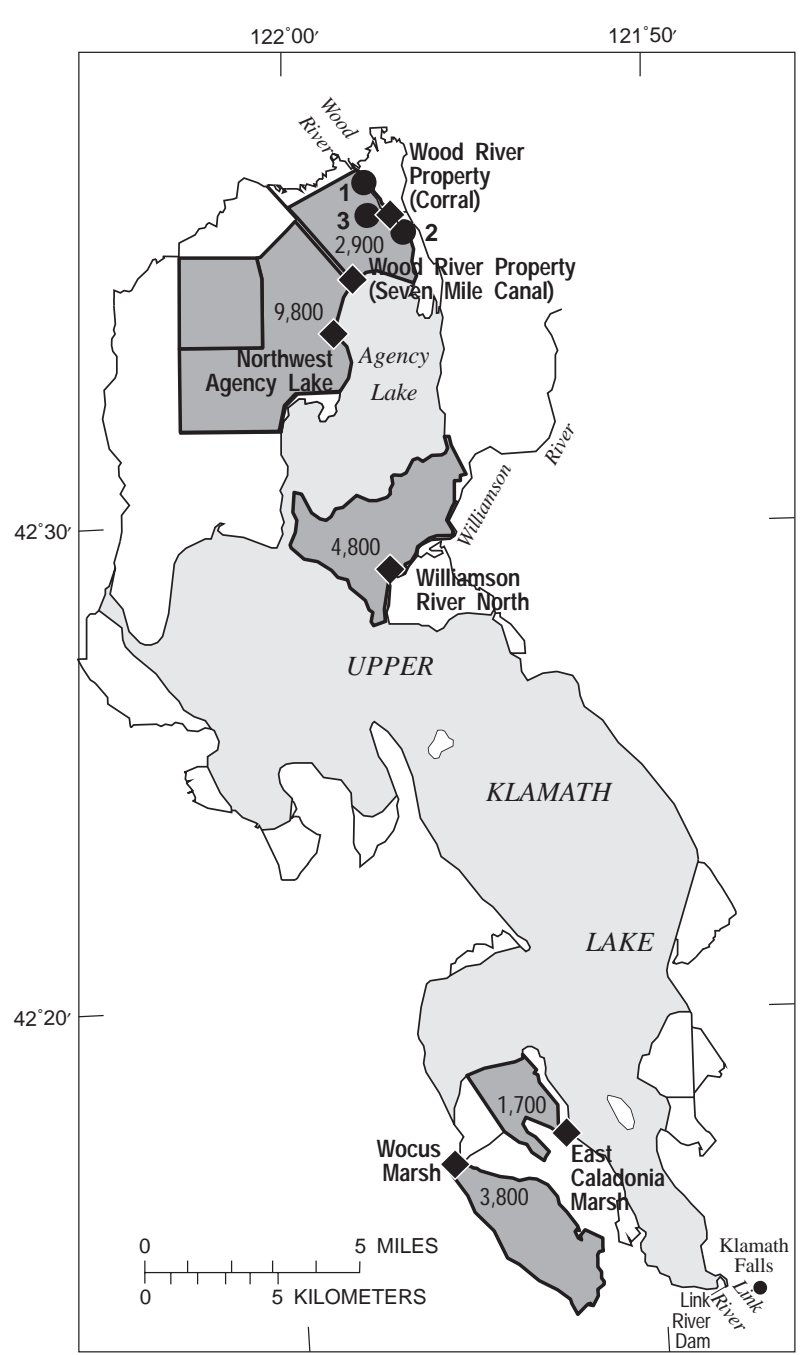

EXPLANATION

Area drained by pumps measured in this study. Number is area in acres.

Flowing artesian well and number. See table 3

Pumping station and name. See table 3

Figure 2. Location of selected drained wetlands, pumping stations, and flowing artesian wells adjacent to Upper Klamath Lake, Oregon.

At the Northwest Agency Lake and Williamson River North pumping stations, however, the discharge pipes are submerged. As a result, the samples were collected from the mouth of the intake pipe at the Northwest Agency Lake station and from an intermediate-discharge access pipe at the Williamson River North station.

Approximately three bottle volumes were collected at each pumping station and then combined into a churn splitter. The churn splitter was used in the field to resuspend the water-sediment mixture prior to subsampling for unfiltered-water analyses. The water remaining in the churn splitter was filtered through a 0.45 -micrometer $(\mu \mathrm{m})$ filter.

Nutrient samples in 1993 and 1994 were preserved with mercuric chloride and chilled to $4^{\circ} \mathrm{C}$. Samples in 1995 were chilled but had no preservative added. Extensive study has demonstrated that both methods of preservation are equivalent (Bartholomay and Williams, 1996). All water-quality samples were immediately stored on ice and shipped to the USGS National Water Quality Laboratory (NWQL) in Denver, Colorado, for analysis.

In addition to the pumping stations, three flowing artesian wells on the Wood River Property (fig. 2) were sampled for nutrients in an attempt to estimate possible ground-water inputs to the property. Well 1 was sampled once each year, whereas wells 2 and 3 were sampled only once each in 1995 . Because the wells were freely flowing, the sample water was collected directly into the churn splitter and then processed as for water-quality samples from the pumping stations.

Quality-assurance samples consisting of replicate splits were collected at four of the six pumping stations and one of the three flowing artesian wells and were included with routine water-quality samples to quantify the precision involved in the process. The replicate split samples were collected by extracting a second sample from the churn splitter during processing. Results of the quality-assurance analyses are in Appendix I.

\section{Analytical Methods}

Water-quality samples were analyzed at the NWQL for ammonia, ammonia plus organic nitrogen, nitrite, nitrite plus nitrate, phosphorus, and orthophosphate in filtered water ${ }^{1}$ and ammonia plus organic nitrogen and phosphorus in unfiltered water ${ }^{2}$. The analytical methods used and their corresponding minimum reporting levels are shown in table 2.

${ }^{1}$ The term "filtered water" is an operational definition referring to the chemical analysis of that part of a water-suspended sediment sample that passes through a nominal $0.45-\mu \mathrm{m}$ filter.

2 Conversely, the term "unfiltered water" refers to the chemical analysis of a water sample that has not been filtered or centrifuged, nor in any way altered from the original matrix. 
Table 2. Methods and minimum reporting levels for nutrients in water sampled adjacent to Upper Klamath Lake, Oregon, 1993-95

[STORET, U.S. Environmental Protection Agency's STOrage and RETrieval system. Method reference number corresponds to: (a) Fishman, 1993; (b) Charles J. Patton, U.S. Geological Survey National Water Quality Laboratory, written commun., 1996; or (c) Patton and Truitt, 1992. $\mathrm{N}$, nitrogen; $\mathrm{P}$, phosphorus ]

\begin{tabular}{|c|c|c|c|c|}
\hline $\begin{array}{l}\text { STORET } \\
\text { code }\end{array}$ & Constituent name & & $\begin{array}{l}\text { Method } \\
\text { reference } \\
\text { number }\end{array}$ & $\begin{array}{c}\text { Minimum } \\
\text { reporting } \\
\text { level } \\
\text { (milligrams } \\
\text { per liter) }\end{array}$ \\
\hline 00608 & $\begin{array}{l}\text { Ammonia as } \mathrm{N} \text {, } \\
\text { filtered and undigested }\end{array}$ & (a) & $\mathrm{I}-2522-90$ & 0.01 \\
\hline 00623 & $\begin{array}{l}\text { Ammonia plus organic } \\
\text { nitrogen as } \mathrm{N} \text {, } \\
\text { filtered and digested }\end{array}$ & (b) & $\mathrm{I}-2515-91$ & .2 \\
\hline 00625 & $\begin{array}{l}\text { Ammonia plus organic } \\
\text { nitrogen as } \mathrm{N} \text {, } \\
\text { unfiltered and digested }\end{array}$ & (b) & I-4515-91 & .2 \\
\hline 00613 & $\begin{array}{l}\text { Nitrite as } \mathrm{N} \text {, } \\
\text { filtered and undigested }\end{array}$ & (a) & $\mathrm{I}-2540-90$ & .01 \\
\hline 00631 & $\begin{array}{l}\text { Nitrite plus nitrate as } \mathrm{N} \text {, } \\
\text { filtered and undigested }\end{array}$ & (a) & I-2546-91 & .005 \\
\hline 00665 & $\begin{array}{l}\text { Phosphorus as } \mathrm{P} \\
\text { unfiltered and digested }\end{array}$ & (c) & $\mathrm{I}-4610-91$ & .01 \\
\hline 00666 & $\begin{array}{l}\text { Phosphorus as P, } \\
\text { filtered and digested }\end{array}$ & (c) & I-2610-91 & .01 \\
\hline 00671 & $\begin{array}{l}\text { Orthophosphate as } \mathrm{P}, \\
\text { filtered and undigested }\end{array}$ & (a) & $\mathrm{I}-2601-90$ & .01 \\
\hline
\end{tabular}

\section{Discharge Determinations}

Discharge was determined once at each pumping station on May 5-6, 1994 (table 3). Each pumping station consisted of one to four individual pumps, each having its own discharge pipe. An electromagnetic velocity meter (model PVM-2A, Montedoro-Whitney Corporation, San Luis Obispo, California) was used to measure the velocity three to four times at each operating pump. The velocity was measured using the "time-averaged" method (Montedoro-Whitney Corporation, 1984, section II) at five of the six stations. This method involves moving the probe continuously over a 40 -second time period in a pattern designed to cover the entire wetted cross-sectional area of the discharge pipe. At the sixth station (Northwest Agency Lake), the meter was used in the "instantaneous" mode to measure velocity in the star pattern (top, bottom, left, right). This method was used because the large velocities and volumes of water at this station made the continuous movement involved in the "time-averaged" method difficult. The diameter of the discharge pipe and wetted height were measured and used to determine the cross-sectional area of water flow. The discharge for each pump was calculated as the product of the wetted cross-sectional area and the mean of the velocity measurements. These discharge values for each pump were summed to calculate a total discharge for each pumping station.

Discharge was measured using a volume method (a certain volume was collected in a given time period) at flowing artesian well 1 in 1994 and at flowing artesian wells 2 and 3 in 1995.

Table 3. Discharge of selected pumping stations and flowing artesian wells adjacent to Upper Klamath Lake, Oregon, 1994-95 [Discharge values for pumping stations were based on the sum of the average $(n=3-4)$ discharge values calculated for each operating pump at a pumping station. Estimated discharge with all pumps operating was based on a ratio of the horsepower of the pumps composing the pumping station. $\mathrm{ft}^{3} / \mathrm{s}$, cubic feet per second; --, not applicable]

\begin{tabular}{|c|c|c|c|c|c|}
\hline Station name & Date & $\begin{array}{l}\text { Number of } \\
\text { operating } \\
\text { pumps }\end{array}$ & $\begin{array}{c}\text { Discharge } \\
\left(\mathrm{ft}^{3} / \mathrm{s}\right)\end{array}$ & $\begin{array}{l}\text { Total horsepower } \\
\text { of pumping } \\
\text { station }\end{array}$ & $\begin{array}{c}\text { Estimated discharge } \\
\text { with all pumps } \\
\text { operating }\left(\mathrm{ft}^{3} / \mathrm{s}\right)\end{array}$ \\
\hline \multicolumn{6}{|c|}{ Pumping stations } \\
\hline Wocus Marsh & $05-05-94$ & 3 of 4 & 15.6 & 130 & 22.5 \\
\hline East Caledonia Marsh & $05-05-94$ & 1 of 1 & .85 & 50 & .85 \\
\hline Williamson River North & $05-06-94$ & 2 of 2 & 26.0 & 200 & 26.0 \\
\hline Northwest Agency Lake & 05-06-94 & 2 of 4 & 100 & 600 & 200 \\
\hline Wood River Property (Seven Mile Canal) & $05-06-94$ & 1 of 1 & 4.30 & 50 & 4.30 \\
\hline Wood River Property (Corral) & 05-06-94 & 1 of 2 & 14.4 & 100 & 28.8 \\
\hline \multicolumn{6}{|c|}{ Flowing artesian wells } \\
\hline Flowing artesian well \#1 & 05-05-94 & -- & $6.3 \times 10^{-3}$ & -- & -- \\
\hline Flowing artesian well \#2 & $05-24-95$ & -- & $5.8 \times 10^{-3}$ & -- & -- \\
\hline Flowing artesian well \#3 & $07-18-95$ & -- & $1.3 \times 10^{-2}$ & -- & -- \\
\hline
\end{tabular}




\section{Soil Samples}

Soil cores were obtained to evaluate the extent and state of decomposition of the organic soils in the drained and undrained wetlands. This was done by describing the soil stratigraphy and collecting samples of material for physical and chemical analysis.

\section{Sampling}

During August 1993, a reconnaissance was made of the soils in the drained and undrained wetlands. Fifteen sites were selected for coring and description. Occasional grab samples were collected, but none were submitted for laboratory analysis. The locations of the cores and summaries of the soil materials are presented in plates 1 and 2, figure 3, and Appendix II. Although these cores provide additional information with regard to the extent and thickness of the organic soils, they were not used in the present analysis because of the lack of complete descriptions.

For the present analysis, coring and sampling took place during the first 3 weeks of August 1995. Eleven drained wetland areas were selected for coring and sampling, representing about 74 percent of the approximately 31,000 acres of drained wetlands adjacent to Upper Klamath Lake (fig. 3, table 4). These areas were selected because they were thought to be representative of the variety of drained wetlands adjacent to the lake with regard to age (time since drainage began) and type of agricultural use.

Five undrained wetland areas were also selected for coring and sampling (fig. 3, table 4) to characterize the physical and chemical properties of the organic materials for undrained wetland areas. The five undrained wetlands constitute nearly all of the 17,400 acres of undrained wetlands around the Upper Klamath Lake. These areas consist of parts of the National and State Wildlife Refuges and the Wood River Marsh, part of which is managed by the Bureau of Land Management and the rest privately held.

Drained and undrained wetland areas were delineated using information from State land-use maps, Natural Resources Conservation Service county soils maps, and USGS 1:24,000-scale topographic maps and orthophotos. These areas are generally designated as peat, muck, or silt loam on county soil maps (Cahoon, 1985) and are within dikes or levees, as shown on USGS topographic maps. The Oregon Water Resources Department land-use map for the Klamath Drainage Basin (Oregon Water Resources Department, 1978) classifies the drained wetlands as "irrigated agriculture" and classifies the undrained wetlands as "other." On some drained wetlands, the shoreward extent of the preexisting undrained wetlands was difficult to discern. In these instances, the 4,140-foot contour on USGS topographic maps was taken to represent the shoreline prior to drainage.

Core sites were selected to provide a good spatial representation of each drained area (fig. 3). During 1995, a total of 61 core sites were selected51 on drained wetland areas and 10 on undrained wetland areas. The locations of all core sites are shown in plates 1 and 2 . The location of each core site was established by use of a global positioning system (GPS) receiver and compared with locations as estimated using a 1:24,000-scale USGS topographic map. The GPS receiver used was a version provided by permission of the U.S. Department of Defense that has a horizontal accuracy of about $50 \mathrm{ft}$ as configured for use during this study. Further details of site location and depth for each core are presented in Appendix II.

Core samples for stratigraphy were obtained using either a Macaulay peat sampler or a Davis soil auger. Most samples were taken using the Macaulay peat sampler, a hand-driven single-person auger that was designed specifically for the retrieval of undisturbed samples of peat suitable for peat stratigraphy investigations (fig. 4). It has attained widespread acceptance in peat investigations (Finney and others 1974; Brown and others, 1984). Through the use of extension rods, it is possible to obtain samples at depths of greater than $25 \mathrm{ft}$ without compacting or distorting the soil material. A large diameter Macaulay sampler was used primarily; however, on a few occasions a small diameter Macaulay sampler was used, particularly for soils having a large content of clay, sand, or gravel. The internal dimensions of the sample chamber (barrel) for the large diameter Macaulay sampler are a length of 20.2 inches and a diameter of 1.4 inches. The sample chamber of the small Macaulay sampler has a barrel 12.1 inches in length and 0.94 inches in diameter. The cores retrieved by the Macaulay samplers are equal in length and diameter to the barrel and are semicircular in section. The sampler cuts the core from the side of the hole after the sampler is inserted into the soil. This helps to retain the original dimensions of the soil material and reduces the amount of disturbance to the sample from the current and previous insertions. The Macaulay peat sampler permits the collection of volumetrically intact samples for use in determining soil bulk density. 


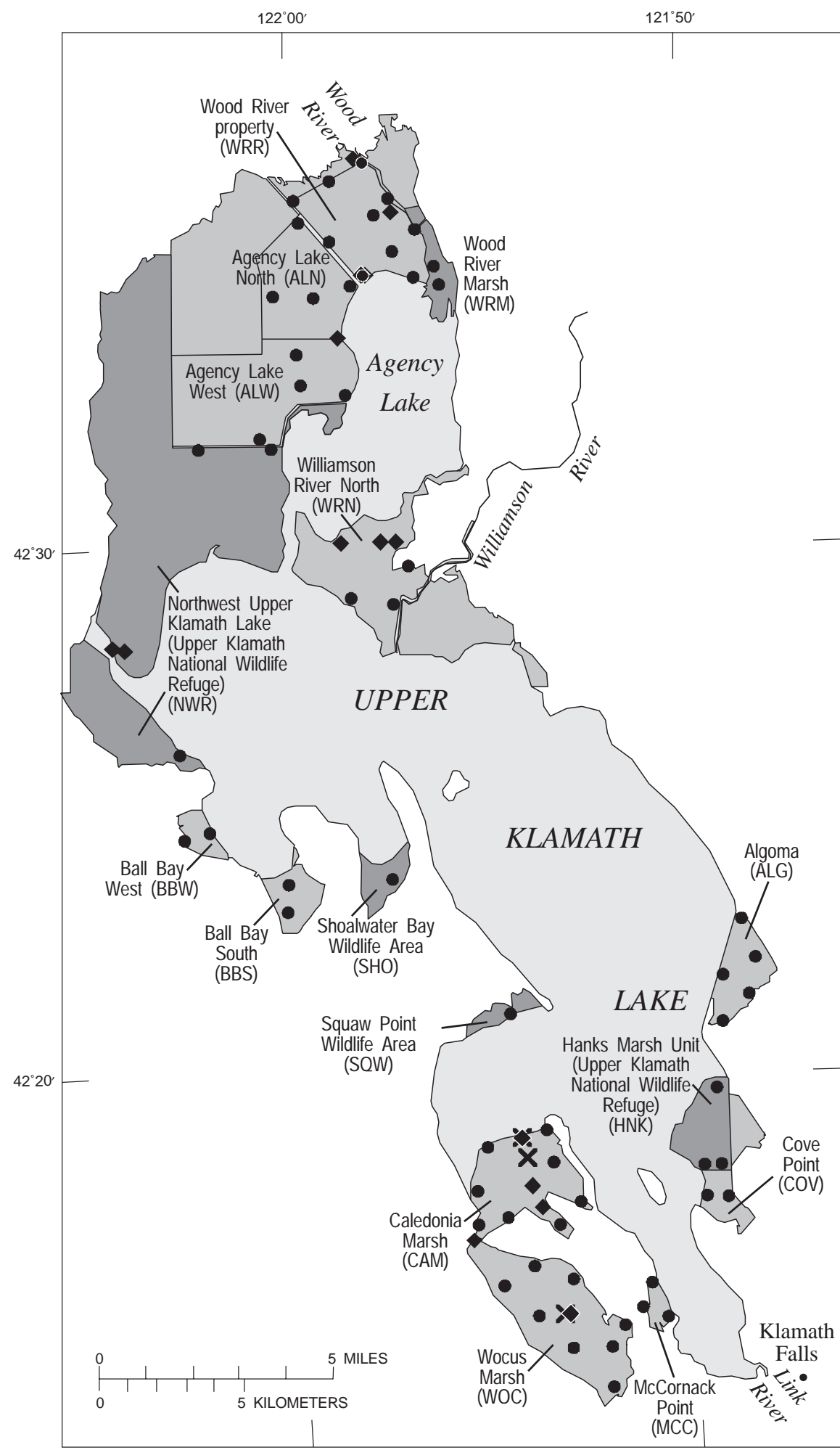

\section{EXPLANATION}

Wetlands drained for agriculture

Undrained wetlands

- 1995 cores

1993 cores

$X$ Cores from other studies (Adams and others, 1994 and
Rosenbaum and others, 1995)

Figure 3. Location of core sites in the drained and undrained wetlands. 
Table 4. Descriptions of drained and undrained wetlands adjacent to Upper Klamath Lake, Oregon, sampled during 1993 and 1995

[BLM, Bureau of Land Management; --, not applicable; USFWS, U.S. Fish and Wildlife Service; ODFW, Oregon Department of Fish and Wildlife]

\begin{tabular}{|c|c|c|c|c|c|}
\hline Name & Abbreviation & $\begin{array}{c}\text { Area } \\
\text { (acres) }\end{array}$ & $\begin{array}{c}\text { Year } \\
\text { drained }\end{array}$ & Land use & $\begin{array}{c}\text { Land } \\
\text { ownership }\end{array}$ \\
\hline \multicolumn{6}{|c|}{ Drained wetlands sampled } \\
\hline McCornack Point & $\mathrm{MCC}$ & 260 & 1889 & Crop cultivation & Private \\
\hline Wocus Marsh & WOC & 3,800 & 1896 & Mixed agriculture $^{1}$ & Private \\
\hline Algoma & ALG & 1,200 & 1914 & Crop cultivation & Private \\
\hline Caledonia Marsh & CAM & 2,500 & 1916 & Crop cultivation & Private \\
\hline Ball Bay South & BBS & 800 & 1919 & Cattle grazing & Private \\
\hline Williamson River North & WRN & 3,200 & 1920 & Crop cultivation & Private \\
\hline Cove Point & $\mathrm{COV}$ & 550 & 1919-40 & Crop cultivation & Private \\
\hline Ball Bay West & BBW & 410 & $1946-47$ & Cattle grazing & Private \\
\hline Wood River Property & WRR & 2,900 & $1940-57$ & Cattle grazing 2 & BLM \\
\hline Agency Lake North & ALN & 2,600 & 1962 & Cattle grazing & Private \\
\hline Agency Lake West & ALW & 4,600 & $1968-71$ & Cattle grazing & Private \\
\hline \multicolumn{6}{|c|}{22,820} \\
\hline \multicolumn{6}{|c|}{ Undrained wetlands sampled } \\
\hline \multicolumn{6}{|c|}{ Upper Klamath National Wildlife Refuge } \\
\hline Northwest Upper Klamath Lake & NWR & 13,800 & -- & Wildlife Refuge & USFWS \\
\hline Hanks Marsh Unit & HNK & 1,200 & -- & Wildlife Refuge & USFWS \\
\hline Shoalwater Bay Wildlife Area & $\mathrm{SHO}$ & 1,300 & -- & Wildlife Refuge & ODFW \\
\hline Wood River Marsh & WRM & 700 & -- & Undefined & $\begin{array}{l}\text { Private } \\
\text { and BLM }{ }^{3}\end{array}$ \\
\hline Squaw Point Wildlife Area & SQW & 370 & -- & Wildlife Refuge & ODFW \\
\hline Total & & 17,370 & & & \\
\hline
\end{tabular}

${ }^{1}$ Crop cultivation and cattle grazing within the same drained area.

2 Area was predominantly used for grazing until 1995 and is presently (1996) undergoing restoration to predrainage conditions.

3 Sampling only performed on BLM portion of Wood River Marsh.

A Davis soil auger was used when unconsolidated soil materials or hardened soils were encountered. This generally occurred in the upper 1 or $2 \mathrm{ft}$ of the surface soils or when compacted clays, sands, or gravels were encountered. The Davis auger is a handdriven single-person device with a barrel 8 inches in length and 4 inches in diameter. The Davis auger cuts material using two circular prongs with the debris accumulating in the central barrel. Samples obtained from the Davis auger can only be approximately located as being between the current hole depth and the depth of the previous soil material collected, thereby diminishing the precision of stratigraphy possible. The Davis auger does not permit the collection of volumetrically intact samples for use in determining soil bulk density.

At each core site, the freshly exposed core or soil material was carefully examined and described in the field with regard to depth and thickness of layers, color, and lithology (content and nature of plant detritus and mineral material), consistency, and sedimentary structures. Each barrel length section of core from the Macaulay peat samplers or soil material from the Davis auger was photographed prior to subsample collection to show the planned location of samples to be collected.

The peat soils were categorized in the field on the basis of fiber content, color, texture, and the degree of decomposition. Preliminary determination of the degree of decomposition was accomplished using the field assessment method devised by Von Post and Granlund and described by Lucas (1982) and Cameron (1989). The determination is based on factors that include the color of the water expelled when peat is squeezed in the hand and the proportion and character of the material which remains in the hand after squeezing. To make a rating, a small quantity of fresh wet peat is squeezed in the palm of the hand. Observations are made as to the nature of squeezed water-clear, turbid, muddy, none; the amount of peat squeezed through fingers-none, little, onethird, two-thirds, all; and the nature of the residueunaltered fibrous, most remains identifiable, some remains identifiable, few identifiable, none identifiable. 


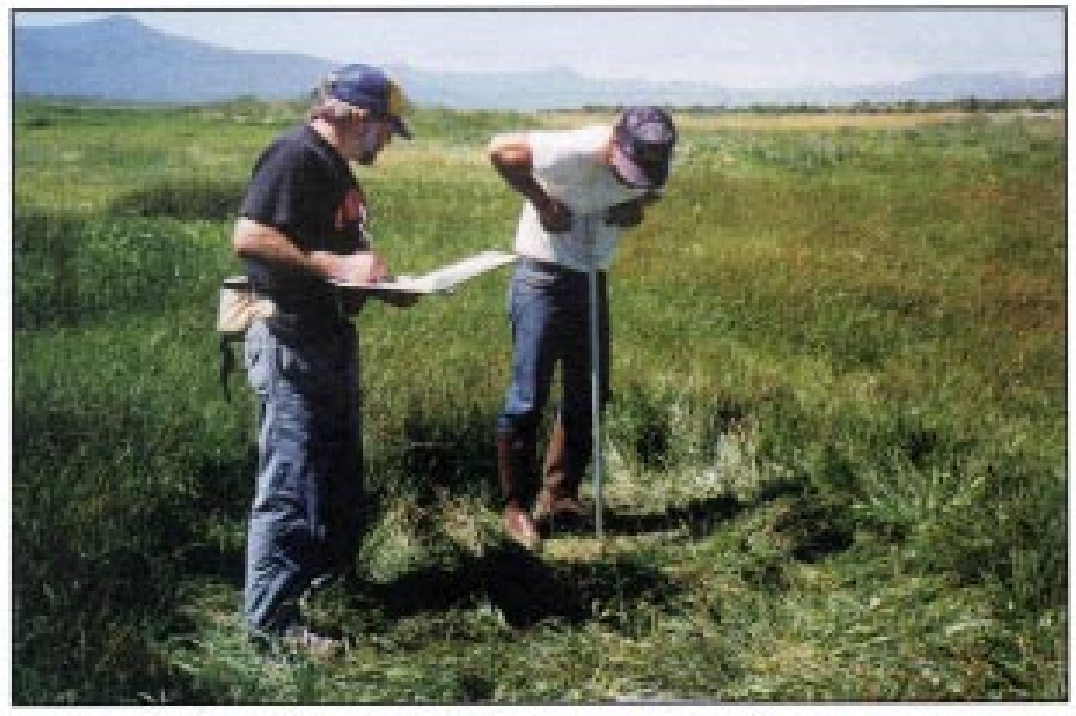

Insertion of Macaulay peat sampler

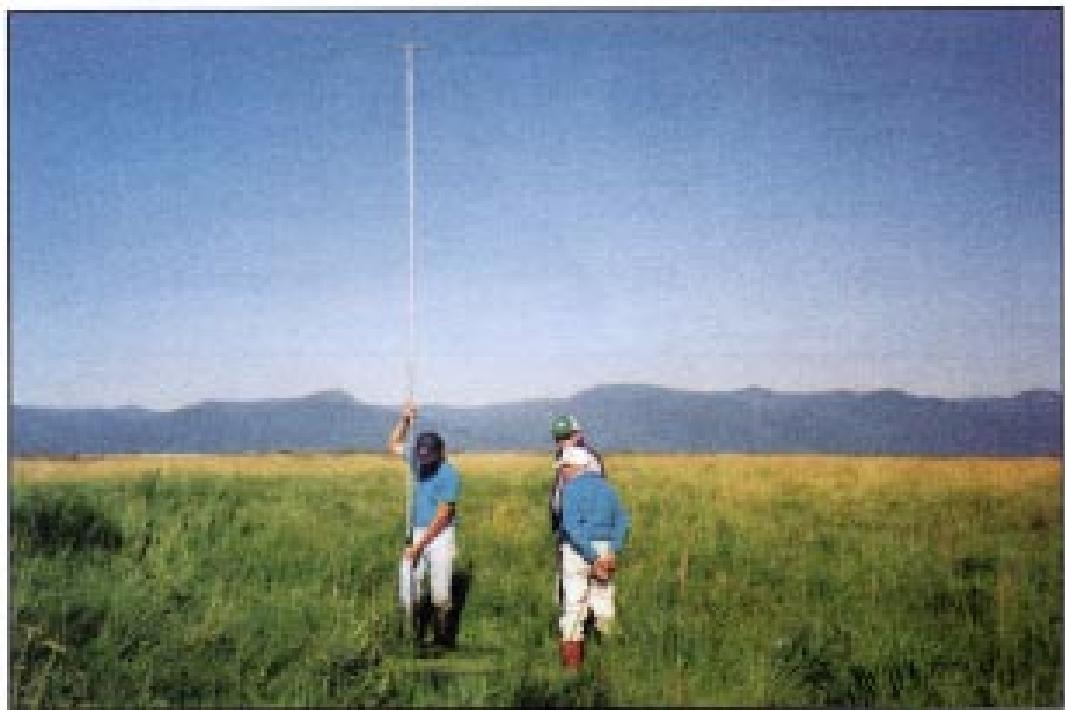

Withdrawal of Macaulay peat sampler

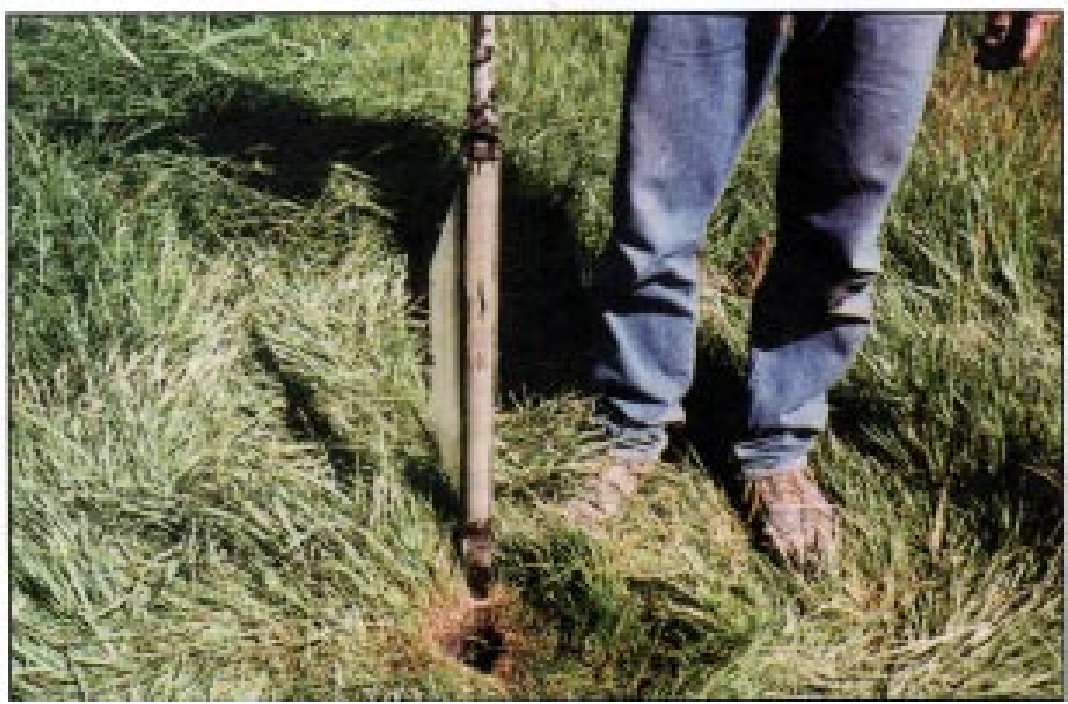

Macaulay peat sampler coened to expose soil sample

Figure 4. Method of soil-core collection from drained and undrained wetlands. 
Although widely used, the method is subject to the bias and experience of the observer and therefore gives only qualitative results and relative comparisons (Chason and Siegel, 1986). For this reason, peat materials were characterized in the field into one of only three groups: hemic peat, hemic/sapric peat, or sapric peat.

Soil coring was stopped when either the soil samplers were unable to penetrate the soil further or a reasonable certainty had been obtained that any organic materials possibly remaining at greater depths were hydraulically isolated. The estimation of hydraulic isolation was based on a judgement that a sufficient depth had been obtained or that sufficient thickness of clay or other inorganic materials having low permeability (the ability to transmit water) had been encountered, or both, such that any organic materials that might be found at greater depths are probably unaffected by land-use activities at the surface. The total depths of the soil cores examined ranged from 2.0 to $18.8 \mathrm{ft}$ and had a mean of $8.8 \mathrm{ft}$ and a median of $9.4 \mathrm{ft}$.

A total of 229 samples of soil materials were collected for possible laboratory analysis of total mass, dry mass, moisture content, ash content, total carbon content, total nitrogen content, nitrite plus nitrate as nitrogen content, and total phosphorus content. In addition, some of the samples were also submitted for determining soil $\mathrm{pH}$, inorganic carbon content, and total inorganic phosphorus content. Samples were selected to represent the prevailing soil types present within the core with emphasis on organic soil materials. Samples also included inorganic soil materials such as clays, sands, pumice, and volcanic ash to help characterize the properties of these materials.

The large Macaulay sampler was used to collect 165 samples, and 10 samples were collected using the small Macaulay sampler. Soil samples were collected from the Macaulay samplers by cutting off a 0.2 to $0.6 \mathrm{ft}$ length of soil material using a stainless steel knife. The Davis auger was used to collect 54 samples. Most of these samples were collected from the near surface. Sample intervals for the Davis auger ranged from 0.1 to $1.0 \mathrm{ft}$. Soil material to be sampled was removed from the barrel of the Davis auger using a stainless steel knife and placed on a clean plastic placard used for description, photo documentation, and sample collection.
Samples were placed in labeled plastic bags that were immediately sealed and stored on ice. The sample location and length were recorded and the unused part of the soil core material was discarded prior to the retrieval of the next length of core or soil material. The samples were later stored in a refrigerator until analyzed to retard biochemical activity. Of the 229 samples collected, 181 were submitted for laboratory analysis. Of these, 136 were from drained areas and 45 from undrained areas. All samples consisting primarily of organic materials (on the basis of observation) were submitted for laboratory analysis. Of the remaining samples, several samples characteristic of soil end-members such as clay, sand, pumice, and volcanic ash were selected for analysis to determine the physical and chemical characteristics of these inorganic soil materials.

\section{Analytical Methods}

Soil samples were analyzed by the Soil, Water, and Plant Testing Laboratory at Colorado State University in Fort Collins, Colorado, using methods published in the Annual Book of ASTM (American Society for Testing and Materials) Standards (Canning and others, 1991); Methods of Soil Analysis American Society of Agronomy, and Soil Science Society of America (Page and others, 1982); and Soil Survey Laboratory Methods Manual (U.S. Department of Agriculture, 1991) (table 5).

Twenty-two replicate-split samples were submitted for analysis in addition to the 181 original samples. Results of the quality-assurance analysis are presented in Appendix I. Replicate-split samples for quality assurance and quality control were collected by dividing a sample in half and labeling with a separate code so that the sample would be unidentifiable as a replicate by the laboratory.

Soil samples were weighed to determine a total mass and milled prior to analysis, and subsamples were taken for the following determinations: Dry mass was determined by drying at $105^{\circ} \mathrm{C}$ and is expressed as the percentage of the total mass, with the remainder equal to the percent moisture content. Percent ash content was determined by igniting the oven-dried sample in a muffle furnace at $750^{\circ} \mathrm{C}$. The substance remaining after ignition is the ash. Ash content is expressed as the percentage of the initial dry mass. Soil $\mathrm{pH}$ was measured using a $\mathrm{pH}$ electrode in a saturated paste of deionized water and soil and is reported in standard $\mathrm{pH}$ units. Total carbon was 
Table 5. Methods and detection limits for analyses of soils sampled adjacent to Upper Klamath Lake, Oregon, 1995 [C, carbon; N, nitrogen; P, phosphorus; mg, milligram; kg, kilogram. Method reference number corresponds to (a) ASTM (American Society for Testing and Materials) (Canning and others, 1991); (b) Soil Survey Laboratory Methods Manual (U.S. Department of Agriculture, 1991); or (c) Methods of Soil Analysis (Page and others, 1982)]

\begin{tabular}{|c|c|c|}
\hline Constituent name and units & $\begin{array}{l}\text { Method } \\
\text { reference } \\
\text { number }\end{array}$ & $\begin{array}{l}\text { Detection } \\
\text { limit }\end{array}$ \\
\hline Dry mass, as percentage of total mass & (a) $2974-87$ & 0.1 percent \\
\hline Percent moisture, as percentage of total mass & (a) $2974-87$ & .1 percent \\
\hline Percent ash content, as percentage of oven-dried mass & (a) 2974-87 & .1 percent \\
\hline Soil $\mathrm{pH}$, in standard $\mathrm{pH}$ units & (b) $8 \mathrm{C} 1 \mathrm{~b}$ & .1 standard $\mathrm{pH}$ units \\
\hline Total carbon, as percentage of oven-dried mass as $\mathrm{C}$ & (b) $6 \mathrm{~A} 2 \mathrm{~d}$ & .1 percent \\
\hline Inorganic carbon, as percentage of oven-dried mass as $\mathrm{C}$ & (b) $6 \mathrm{E} 1 \mathrm{c}$ & .01 percent \\
\hline Total nitrogen, as percentage of oven-dried mass, as $\mathrm{N}$ & (c) $31-1$ & .01 percent \\
\hline Nitrite plus nitrate, as $\mathrm{mg}$ of $\mathrm{N}$ per $\mathrm{kg}$ of oven-dried mass & (c) $33-2$ & $1 \mathrm{mg} / \mathrm{kg}$ \\
\hline Total inorganic phosphorus, as $\mathrm{mg}$ of $\mathrm{P}$ per $\mathrm{kg}$ of oven-dried mass & (c) $24-4.2$ & $1 \mathrm{mg} / \mathrm{kg}$ \\
\hline Total phosphorus, as mg of $\mathrm{P}$ per $\mathrm{kg}$ of oven-dried mass & (c) $24-2.3$ & $10 \mathrm{mg} / \mathrm{kg}$ \\
\hline
\end{tabular}

determined by dry combustion using a Leco CHN (carbon-hydrogen-nitrogen) furnace and is reported as the percentage of the oven-dried mass, as carbon. Inorganic carbon (carbonate carbon) was determined by weight loss with the addition of hydrochloric acid and is reported as the percentage of the oven-dried mass, as carbon. Total nitrogen was determined using a Leco $\mathrm{CHN}$ furnace and is reported as the percentage of the oven-dried mass, as nitrogen. Nitrite plus nitrate was determined using a 2 molar potassium chloride extract and analysis by flow injection using zinc reduction and is reported as the milligrams of nitrogen per kilogram of the oven-dried mass. Total inorganic phosphorus was determined using a sequential extraction and is reported as the milligrams of phosphorus per kilogram of the oven-dried mass. Analysis of total phosphorus (TP) was performed using a perchloric acid digestion and is reported as the milligrams of phosphorus per kilogram of the oven-dried mass.

Total carbon in soils is the sum of organic and inorganic carbon. Most of the organic carbon is associated with the organic matter fraction, and the inorganic carbon is generally found with carbonate minerals (U.S. Department of Agriculture, 1996). The difference between total and inorganic carbon is an estimate of the organic carbon. Of 46 samples analyzed for inorganic carbon, 42 samples (91 percent) had values below the detection limit. Of the remaining four samples, two were either sand or clay. The remaining two samples were of sapric peats taken from cores near the mouths of small drainages at the southern end of Caledonia Marsh. Inorganic carbon accounted for less than 0.2 percent of the total carbon. On the basis of these results, total carbon was used as an estimate of the total organic carbon.

Total nitrogen (TN) in the soils, as used in this report, is the sum of organic and inorganic nitrogen. The inorganic nitrogen generally occurs as nitrate or nitrite. Inorganic nitrogen accounted for less than 3 percent of the total nitrogen for any of the samples analyzed.

Bulk density was calculated as the dry mass at $105^{\circ} \mathrm{C}$, determined by laboratory analyses, divided by the volume of the sample collected. The volumes of the sampling chambers of the large and small Macaulay samplers were determined by displacement of water. The large sampler had a volume of $268 \mathrm{~cm}^{3}$ (cubic centimeter) and the small sampler had a volume of $69 \mathrm{~cm}^{3}$. Because the samples consisted of a partial length of the core sample obtained using the Macaulay samplers, the sample volume was calculated as the sample length divided by the length of the Macaulay sample chamber, multiplied by the measured volume of the entire sample chamber. As previously discussed, it was not possible to calculate the bulk density of samples collected using the Davis auger. Therefore, the 29 samples of sapric peat collected from the drained wetlands using the Davis auger were assigned a bulk density of $0.2448 \mathrm{~g} / \mathrm{cm}^{3}$ (grams per cubic centimeter), the median value for drained sapric peats collected using the Macaulay samplers. 


\section{Data Analysis}

\section{Estimation of Nutrient Loads Using Sampling and Measurement of Pump Discharge}

Nutrient concentrations were measured during 1993-95 and the electrical meters associated with the pumping stations were monitored to determine the annual volume of water pumped based on the power consumption in May 1994. Given the concentration and volume of water pumped during the water year ${ }^{3}$, an annual load can be calculated. It is important to note that this method gives a crude estimate and has many assumptions and inherent errors associated with it (these assumptions are listed in the "Limitations and Concerns Involved in Calculations of Nutrient Loads and Yields" section under this heading). For these reasons, these loading estimates should be used only as an indication of the order of magnitude of nutrient contributions from these areas.

\section{Calculation of Volume of Water Pumped}

The volume of water pumped from the drained wetlands was estimated from power-consumption data using an adaptation of the method detailed by Hurr and Litke (1989). To determine this volume, a relation was established between the volume of water pumped and the energy consumed. This relation is represented by the power-consumption coefficient (PCC), which is the ratio of the instantaneous power demand to the simultaneously measured discharge.

The power demand is calculated by:

$$
P=\text { rate } \times \text { Kh factor } \times M \times 3.6,
$$

where:

$$
\begin{aligned}
P= & \text { instantaneous power demand, } \\
& \text { in kilowatts }(\mathrm{kW}) ; \\
\text { rate }= & \text { the average rate of disk revolution, } \\
& \text { in revolutions per second; } \\
\text { Kh factor }= & \text { the disk constant, in watt-hours per } \\
& \text { revolution; } \\
M= & \text { the meter multiplier, unitless; and } \\
= & \text { a conversion factor for watts to } \\
& \text { kilowatts and seconds to hours. }
\end{aligned}
$$

\footnotetext{
${ }^{3}$ A water year is the 12-month period beginning October 1 and ending September 30 in the following year. The water year is designated by the calendar year in which it ends. The pumping season is generally from March to September with little pumping outside this time period.
}

The Kh factor and meter multiplier are printed on the meter.

The power demand is then divided by the corresponding discharge for the pumping station to yield the PCC. The PCC values calculated for these pumping stations are given in table 6. According to Hurr and Litke (1989), for open-discharge irrigation wells powered by electricity and pumping ground water from a depth of less than $50 \mathrm{ft}$, typical values of PCC range from 75 to $150 \mathrm{kWhr}$ /acre-ft (kilowatt-hours per acre-foot) of water. The values for the Northwest Agency Lake pumping station and Wood River Property (Corral) pumping station are low when compared to this range, but they had respective lifts of only $2.0 \mathrm{ft}$ and $7.8 \mathrm{ft}$ when measured. For any of the pumping stations, the maximum lift is about $20 \mathrm{ft}$, but typically less than that, and the maximum head change is only about $5 \mathrm{ft}$ during the water year.

Because the discharge at each pumping station was measured only once (in May 1994) during the study period (1993-95), the PCC established for May 1994 was used to calculate volumes throughout the study period. This practice was based on the assumption that the relation between pumping rate and power demand is constant. This relation is not always constant, however, as described by Hurr and Litke(1989, p. 24).

For example, pumping head may increase due to drawdown from extensive pumpage, pump efficiency may decrease as the pump ages, and changes in the irrigation-water distribution system may alter the load against which the pump must work.

In this study, however, pumping head changed by only about $5 \mathrm{ft}$ over the year, and pump efficiency is not expected to greatly change over a 3-year period.

Once the PCC has been established for the pumping station, the volume of water pumped during a given time frame can be calculated based on the electrical meter readings at the bounds of the time frame. For this report, an estimate of the annual load was desired, so the volume of water pumped was determined for the water year. By using the monthly meter readings, the volumes pumped during these time periods can be summed to determine an annual volume of water pumped. 
Table 6. Power-meter information, power demand, discharge, power-consumption coefficient, and lift for selected pumping stations adjacent to Upper Klamath Lake, Oregon, May 5-6, 1994

[East Caledonia Marsh pumping station was excluded because there were too few data to calculate loads. Whr/rev, watt-hours per revolution; kW, kilowatts; $\mathrm{ft}^{3} / \mathrm{s}$, cubic feet per second; PCC, power-consumption coefficient; $\mathrm{kWhr} / \mathrm{acre}-\mathrm{ft}$, kilowatt-hours per acre-foot of water]

\begin{tabular}{|c|c|c|c|c|c|c|}
\hline Pumping station & $\begin{array}{l}\text { Kh factor } \\
\text { (Whr/rev) }\end{array}$ & $\begin{array}{c}\text { Meter } \\
\text { multiplier } \\
\text { (unitless) }\end{array}$ & $\begin{array}{c}\text { Power } \\
\text { demand } \\
(\mathrm{kW})\end{array}$ & $\begin{array}{c}\text { Discharge } \\
\left(\mathrm{ft}^{3} / \mathrm{s}\right)\end{array}$ & $\begin{array}{c}\text { PCC } \\
\text { (kWhr/acre-ft) }\end{array}$ & $\begin{array}{c}\text { Average } \\
\text { lift } \\
\text { (feet) }\end{array}$ \\
\hline Wocus Marsh & 4.8 & 80 & 88.7 & 15.6 & 68.9 & 5.6 \\
\hline Williamson River North & 3.6 & 40 & 180.5 & 26.0 & 84.1 & 10.1 \\
\hline Northwest Agency Lake & 3.6 & 120 & 180.6 & 100 & 21.8 & 2.0 \\
\hline Wood River Property (Seven Mile Canal) & 43.2 & 1 & 42.0 & 4.30 & 118 & 16.7 \\
\hline Wood River Property (Corral) & 1.2 & 160 & 44.1 & 14.4 & 36.9 & 7.8 \\
\hline
\end{tabular}

\section{Calculation of Nutrient Loads and Yields}

The annual nutrient loads were calculated as the product of the annual volume of water pumped and the annual median concentrations. In this study, loads were determined for total nitrogen and total phosphorus. Total phosphorus concentrations are equal to the measured values from the analysis of phosphorus in unfiltered water. Total nitrogen concentrations are calculated by adding the results of the analyses for ammonia plus organic nitrogen in unfiltered water and nitrite plus nitrate nitrogen in filtered water.

Although all six pumping stations were monitored from 1993 through 1995, loads were only calculated for stations and years having three or more nutrient determinations (note that the maximum number of samples for any station and year was five). This limitation excludes the East Caledonia Marsh pumping station from the annual load calculations. Also, the two pumping stations at Wood River Property drain the same area; therefore, the volumes of water pumped were calculated for each pumping station and then added to yield one volume to be used in calculating the annual load for the area. Because of these limitations on the analysis, loads were calculated for only 8 of the possible 18 year-station combinations.

By dividing the annual nutrient load by the drained area that it represents (fig. 2), an annual nutrient yield is obtained. The yield is an area-normalized value that makes inter-area comparisons possible. The load value is related to the size of the drained area, whereas the yield value is based on a common unit of area and is not affected by the size of the drained land area.

\section{Limitations and Concerns Involved in Calculations of Nutrient Loads and Yields}

Many assumptions and inherent errors are associated with the calculations of nutrient loads and yields. An estimate of error is not provided with the calculated loads and yields because it is not possible to quantify the error associated with each of the assumptions. For these reasons, the calculated nutrient loads and yields should be used only as an order-of-magnitude estimation with consideration of the limitations and concerns listed below.

- The relation between pumping rate and power demand is assumed to be constant over the study period (1993-95).

This assumption, that the pumping head and pump efficiency remained constant, is not true. Pumping head only changed, however, by about $5 \mathrm{ft}$ over the year, and the pump efficiency is not expected to greatly change over a 3 -year period.

- The annual nutrient concentration is assumed to be represented sufficiently by the median concentration from at least three samples collected during the year.

The ability of the median to adequately represent the annual nutrient concentration depends on the number of data points and their distribution. For these data the range/median ratio varied from 7 to 250 percent. Conceptually, the nutrient concentrations are expected to increase as the pumping season progresses - as the lowconcentration standing water is removed and subsequent drainage of the high-concentration pore waters occurs. This trend, however, was not always apparent in the data. 
- The loads calculated are an integration of all possible inputs/outputs and not a treatment of each source individually.

Possible inputs of nutrients include:

decomposition of the peats;

fertilizer applications;

cattle waste deposition;

waterfowl waste deposition;

precipitation;

atmospheric deposition;

fixation of atmospheric nitrogen by

microorganisms associated with plants;

seepage through the dikes from the lake,

adjacent river, or canal;

flood irrigation from the lake, adjacent river, or canal;

sprinkler irrigation from the adjacent river

or canal; and

runoff from adjacent land

(particularly at the Wocus Marsh and

East Caledonia Marsh pumping stations).

Possible outputs include:

agricultural products;

cattle uptake;

waterfowl uptake;

erosion by wind and water;

denitrification; and

ammonia volatilization.

- Loads calculated for all pumping stations, except Wocus Marsh, are primarily delivered to the lake or its tributaries.

The load calculated for the Wocus Marsh pumping station, however, is not always directed to the lake. During some times of the year, the pumped water is diverted from entering the lake and is recirculated for irrigation within the Wocus Marsh.

- The primary area drained by the pumping station at Northwest Agency Lake is about 7,200 acres; however, this pumping station is sometimes used to drain an additional 2,600 acre area. Although there is a 30-horsepower pump in the additional area, the pumps in the Northwest Agency Lake pumping station total 600 horsepower and, therefore, are considered the primary pumping device.
The total area of 9,800 acres was used for the drained area in the yield calculations for the Northwest Agency Lake area.

\section{Estimation of Nutrient Loss Using Change in Nutrient Mass of Drained Wetland Soils}

The cumulative loss of nutrients from soils of the drained wetlands was determined by estimating the present-day nutrient mass and subtracting this from an estimate of the initial nutrient mass prior to drainage. The change in nutrient mass is an estimate of the maximum amount of nutrients from the drained wetland soils that could have been pumped into Upper Klamath Lake. Estimates of annual nutrient loss were determined by calculation of decay rates for the period from when drainage began to the present.

\section{Calculation of Present-Day Peat and Nutrient Masses}

The present-day nutrient mass of the peat materials within each drained wetland was determined from the volume, bulk density, and nutrient concentrations of peat layers obtained from the analysis of soil cores. This method was used by Laine and others (1992) to estimate the stores of carbon in peat layers of drained wetlands. Layers of peat material are not necessarily continuous over the entire drained area. Therefore, each area was subdivided by using Theissen polygons. The method of Theissen polygons assumes that the influence of any core site can be applied halfway to the next core site in any direction (Chow, 1964). The polygons are constructed by plotting the locations of all the core sites within a drained area and drawing connecting lines between the sites. The perpendicular bisectors for each connecting line are then found and joined to form a polygon around each core site (fig. 5).

Data from the core site in the polygon is used to represent the entire polygonal area. This method is generally more accurate than simple arithmetical averaging (Linsley and others, 1982).

The dry mass of peat in each layer is the product of the layer volume and its bulk density. Similarly, the mass of nutrient in each layer is the product of the layer volume, bulk density, and it nutrient concentration. Summing the masses for all the layers of all the Theissen polygons in a wetland area produces the present-day mass for the area. This calculation is detailed in figure 5 and a sample calculation is presented in table 7 . 


\section{Conceptual Model}

del

\section{Equations}

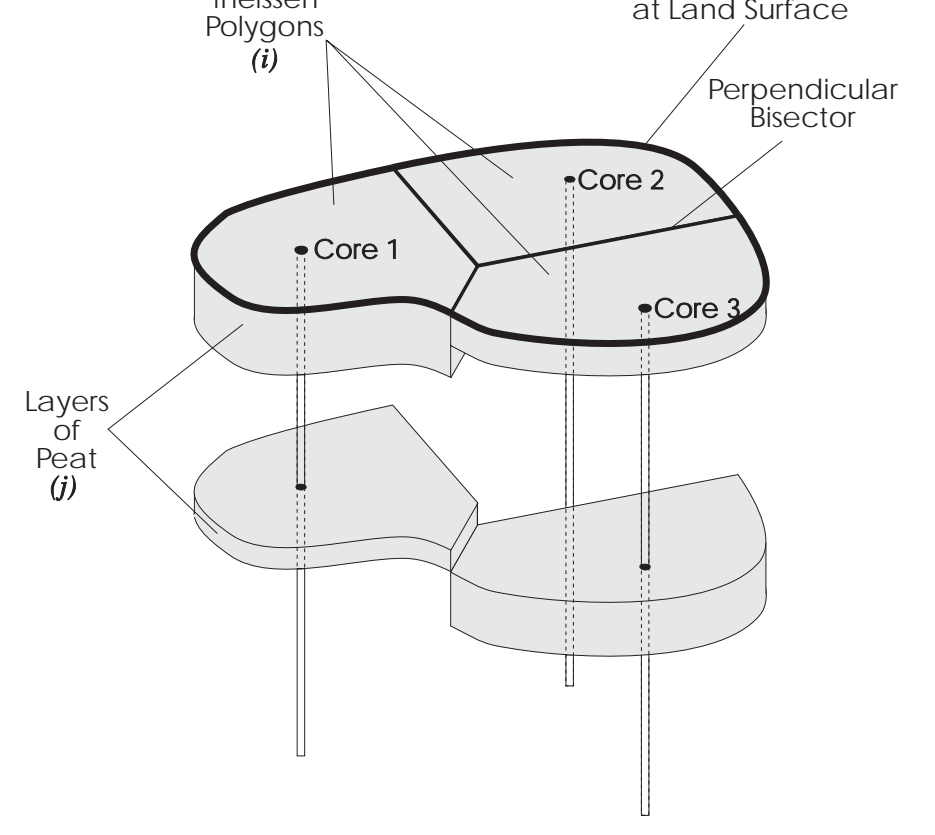

Present-day peat mass:

$$
\mathrm{M}=\sum_{i=1}^{n} \sum_{j=1}^{\iota_{i}}\left(A_{i} h_{i, j} \rho_{i, j}\right)
$$

Present-day nutrient mass:

$$
N=\sum_{i=1}^{n} \sum_{i=1}^{l_{i}}\left(A_{i} h_{i, j} \rho_{i, j}\right) C_{i, j}
$$

Initial peat mass (prior to drainage):

$$
M^{\mathrm{o}}=\sum_{i=1 j=1}^{n} \sum_{i=1}^{\iota_{i}}\left(A_{i} h_{i, j} \rho_{i, j}\right)\left(\frac{R_{i, j}}{R^{\mathrm{o}}}\right)
$$

Initial nutrient mass (prior to drainage):

$$
N^{\mathrm{o}}=\sum_{i=1}^{n} \sum_{i=1}\left(A_{i} h_{i, j} \rho_{i, j}\right)\left(\frac{R_{i, j}}{R^{\mathrm{o}}}\right) C^{\mathrm{o}}
$$

where:

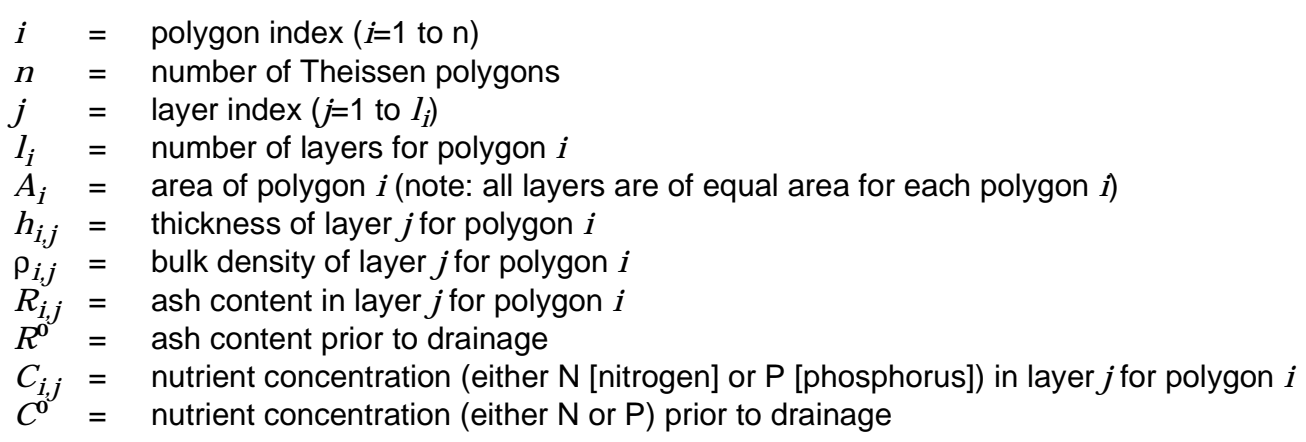

Figure 5. Calculation of peat and nutrients of a drained wetland area. (The conceptual model and equations pertain to a hypothetical drained wetland area containing three core sites. Cores 1 and 3 each intersect two peat layers that are separated by clay or other mineral soil; core 2 intersects only one peat layer.) 
Table 7. Sample calculation of peat and nutrients of a drained wetland area

[See figure 5 for conceptual model and equations used in the sample calculation. Data for the sample calculation are not from an actual site. Values of initial ash content $\left(R^{o}\right)$ and initial total nitrogen concentration $\left(C^{o}\right)$ used in calculations are 52 and 2.4 percent dry mass, respectively. Initial is prior to the beginning of drainage of a wetland for agricultural use. Present day is 1995 . Cumulative loss is the difference between initial and present day. Values calculated for individual layers are presented using two significant figures. Sums were calculated using masses for individual layers and are rounded to the nearest 10,000 and 100 tons for peat and total nitrogen, respectively.]

\begin{tabular}{|c|c|c|c|c|c|c|}
\hline & \multicolumn{2}{|c|}{ Core 1} & Core 2 & \multicolumn{2}{|c|}{ Core 3} & Total \\
\hline & \multicolumn{5}{|c|}{ Input values } & \\
\hline Area (acres) & \multicolumn{2}{|c|}{$A_{1}=800$} & $A_{2}=1,000$ & \multicolumn{2}{|c|}{$A_{3}=900$} & 2,700 \\
\hline Number of layers & \multicolumn{2}{|c|}{$l_{1}=2$} & $l_{2}=1$ & \multicolumn{2}{|c|}{$l_{3}=2$} & -- \\
\hline $\begin{array}{l}\text { Layer thickness } \\
\text { (feet) }\end{array}$ & $h_{1,1}=2.4$ & $h_{1,2}=0.9$ & $h_{2,1}=1.8$ & $h_{3,1}=1.2$ & $h_{3,2}=2.0$ & -- \\
\hline $\begin{array}{l}\text { Bulk density of layer } \\
\text { (grams per cubic centimeter) }\end{array}$ & $\rho_{1,1}=0.24$ & $\rho_{1,2}=0.16$ & $\rho_{2,1}=0.25$ & $\rho_{3,1}=0.23$ & $\rho_{3,2}=0.13$ & -- \\
\hline $\begin{array}{l}\text { Total nitrogen concentration } \\
\text { (percent dry mass) }\end{array}$ & $C_{1,1}=1.4$ & $C_{1,2}=1.8$ & $C_{2,1}=0.8$ & $C_{3,1}=1.2$ & $C_{3,2}=2.0$ & -- \\
\hline \multirow[t]{2}{*}{$\begin{array}{l}\text { Ash content } \\
\text { (percent dry mass) }\end{array}$} & $R_{1,1}=58$ & $R_{1,2}=53$ & $R_{2,1}=62$ & $R_{3,1}=60$ & $R_{3,2}=54$ & -- \\
\hline & \multicolumn{5}{|c|}{ Calculated peat mass } & \\
\hline $\begin{array}{l}\text { Present day } \\
\quad \text { (tons) }\end{array}$ & 630,000 & 160,000 & 610,000 & 340,000 & 320,000 & $2,060,000$ \\
\hline $\begin{array}{l}\text { Initial } \\
\quad \text { (tons) }\end{array}$ & 700,000 & 160,000 & 730,000 & 390,000 & 330,000 & $2,310,000$ \\
\hline \multirow[t]{2}{*}{$\begin{array}{l}\text { Cumulative loss } \\
\text { (tons) }\end{array}$} & 70,000 & 0 & 120,000 & 50,000 & 10,000 & 250,000 \\
\hline & \multicolumn{5}{|c|}{ Calculated total nitrogen mass and yield } & \\
\hline $\begin{array}{l}\text { Present day } \\
\text { (tons) }\end{array}$ & 8,800 & 2,800 & 4,900 & 4,100 & 6,400 & 27,000 \\
\hline $\begin{array}{l}\text { Initial total } \\
\quad \text { (tons) }\end{array}$ & 17,000 & 3,800 & 18,000 & 9,400 & 7,900 & 56,100 \\
\hline $\begin{array}{l}\text { Cumulative loss } \\
\text { (tons) }\end{array}$ & 8,200 & 1,000 & 13,100 & 5,300 & 1,500 & 29,100 \\
\hline $\begin{array}{l}\text { Cumulative loss } \\
\text { (pounds per acre) }\end{array}$ & -- & -- & -- & -- & -- & 22,000 \\
\hline
\end{tabular}

\section{Calculation of Initial Peat and Nutrient Masses Prior to Drainage}

When a peat soil is drained and exposed to oxygen, the organic portion undergoes aerobic decomposition but the inorganic (mineral) component does not. Over time, the organic content decreases and the inorganic residue, or ash, becomes proportionally more concentrated. This proportional increase in the ash content can be used to estimate the mass of peat before drainage and subsequent decomposition (fig. 5 , table 7). The calculation hinges on the following assumptions:

1. Ash is conservative - that is, ash is not lost during or after decomposition.
2. All peat soils in the wetlands adjacent to Upper Klamath Lake had the same initial ash content before decomposition.

3. Present-day undrained wetlands are representative of the drained wetlands prior to drainage.

This method is similar to that of Broadbent (1960), Segeberg (1962, as cited in Eggelsmann, 1976), and Laine and others (1992). Similarly, the initial nutrient mass can be estimated if it is also assumed that all the peat soils in the wetlands had the same initial nutrient concentration before decomposition (fig. 5, table 7). Initial masses will be underestimated if ash or nutrients are lost by wind or water erosion, uptake by crop or forage, or leaching by water. 
The reference values of initial ash content $\left(R^{0}\right)$ and initial nutrient content $\left(\mathrm{C}^{\mathrm{O}}\right)$ were estimated from data from present-day undrained wetlands adjacent to Upper Klamath Lake. Initial values were determined by minimizing the differences between the calculated and observed present-day ash or nutrient mass per area summed over all peat layers encountered by the soil cores from the undrained wetlands (table 8). The mass per area was used because it incorporates a weighting by layer thickness and bulk density.

If the estimate of initial mass of peat was less than the present-day mass, it indicates that the initial ash content was over estimated or that the present-day ash content was underestimated, perhaps as a result of erosional losses. This situation occurred for 54 percent of the layers. In these instances, it was assumed that no decomposition took place and the initial peat mass was set equal to the present-day mass in the layer.

If the estimate of initial masses of nitrogen or phosphorus were less than the present day masses, either the initial peat mass or nutrient content was underestimated or the present-day masses received additional inputs of nutrients, perhaps as a result of fertilizer or animal waste. This situation occurred for 0 and 14 percent of the layers for nitrogen and phosphorus, respectively. In these instances, the initial phosphorus mass was set equal to the presentday mass in the layer.

\section{Calculation of Peat and Nutrient Loss Since Drainage}

The cumulative loss of peat and nutrient mass from the drained wetland soils since drainage was calculated as the initial mass minus the present-day mass. This calculation was performed on individual peat layers within each Theissen polygon and the results were summed to determine the loss in mass of peat, $\mathrm{TN}$, and TP for each drained wetland.

\section{Calculation of Decay Rates and Annual Estimates of Peat and Nutrient Loss}

Estimates of annual losses of nutrients from the peat soils of the drained wetlands are needed to facilitate comparisons with estimates of annual nutrient loading to Upper Klamath Lake. Initial and presentday masses and length of time since drainage began were used to calculate rate constants $(k)$ according to the first-order rate law:

$$
A_{t}=A e^{-k t}
$$

where:

$A_{t}=$ nutrient mass of drained wetland at time $\mathrm{t}$, in tons;

$A=$ initial nutrient mass of drained wetland at start of drainage, in tons;

Table 8. Calculation of initial ash and nutrient content

[S, sum of residual differences; $c$, core index $(c=1$ to $n)$; $n$, number of cores in all undrained wetlands; $j$, layer index $\left(j=1\right.$ to $\left.l_{c}\right) ; l_{c}$, number of layers for core $c ; h_{c, j}$, thickness of layer $j$ for core $c ; \rho_{c, j}$, bulk density of layer $j$ for core c; $R_{c, j}$, ash content in layer $j$ for core $c ; R^{o}$, initial ash content; $C_{N c, j}$, nitrogen content in layer $j$ for core $c$; $C_{N}{ }^{o}$, initial nitrogen content; $C_{P c, j}$, phosphorus content in layer $j$ for core $c$; $C_{P}{ }^{o}$, initial phosphorus content; mg, milligrams; $\mathrm{kg}$, kilograms]

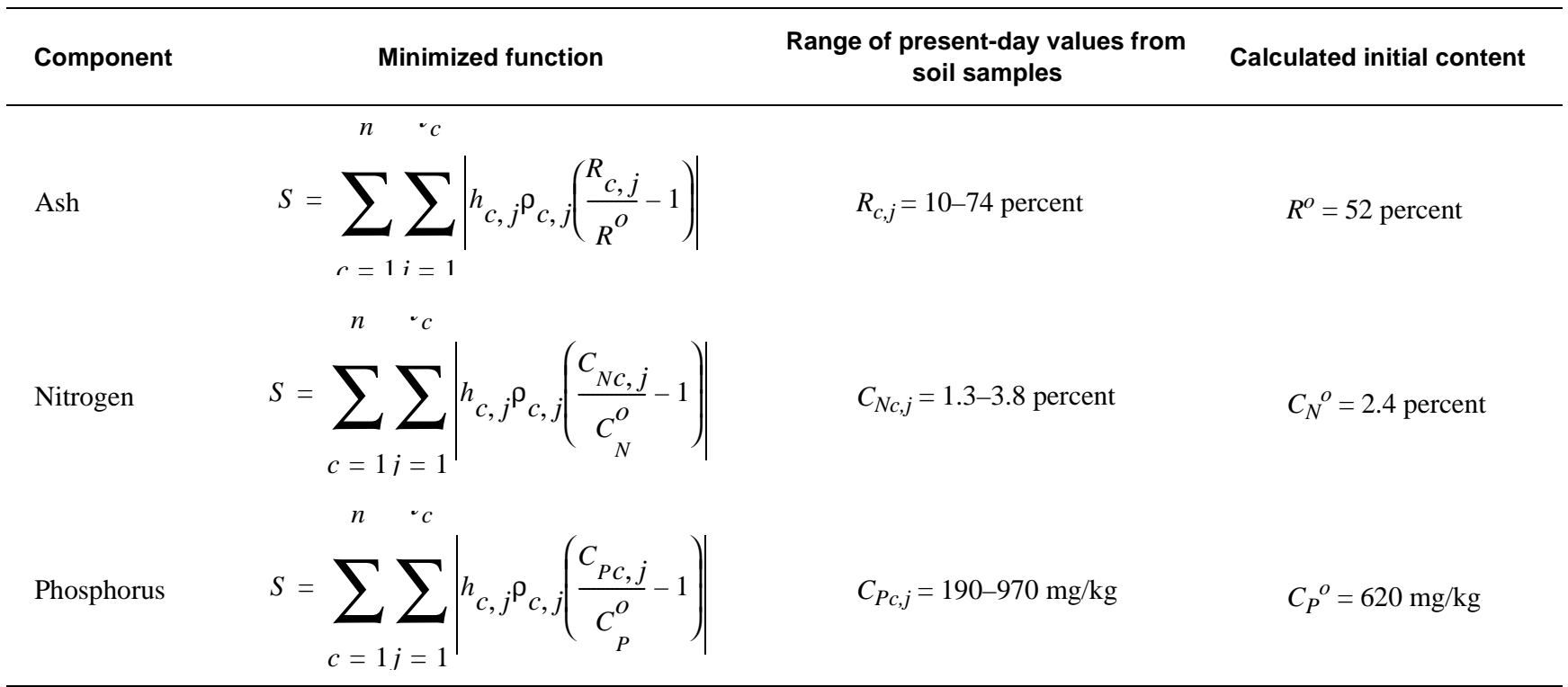


$e=$ base of Napierian logarithms, 2.71828, dimensionless;

$k=$ rate constant, in 1/years; and

$t=$ time since drainage of wetland began, in years.

Equation 2 gives the nutrient mass $A_{t}$ that remains at any time $t$ of the initial nutrient mass $(A)$ that was present prior to drainage of the wetland $(t=0)$. The rate constant $(k)$ is the fraction of the nutrient mass that is lost on an annual basis and, when multiplied by 100 , can be expressed as a percentage using units of percent per year. Rate constants were individually determined for TN and TP for each drained wetland area. The rate constants were used to calculate the nutrient mass existing at each drained wetland for the following pairs of consecutive years: 1965 and 1966, 1992 and 1993, 1993 and 1994, and 1994 and 1995.

The difference between the nutrient masses calculated for any 2 consecutive years is the annual nutrient loss for that time period.

A first-order rate law is one of several possible models that might describe the decomposition of peat soils from the drained wetlands. Many factors influence the rate of decomposition. Rates may vary spatially within individual drained areas or temporally due to weather or changes in land-use management. These factors have not been incorporated in the present model. Therefore, annual nutrient losses calculated from the model should not be expected to accurately represent losses for a particular year which result from specific conditions.

\section{DESCRIPTION OF SOILS ON UNDRAINED AND DRAINED WETLANDS}

A comparison of the character and composition of the undrained and drained wetland soils provides insight into the effects of decomposition of the organic materials. The observation of these differences formed the basis for the analysis of nutrient loss from the drained wetlands soils and the possible significance of land use.

\section{Initial Soil Properties of Undrained Wetlands}

Soil cores from the peat materials in the undrained wetlands show the following sequence of beds from the bottom upward: clay, clay with hemic peat, hemic peat with clay, hemic peat (plates 1 and 2).
This sequence or cycle is sometimes repeated, as in both cores from the Wood River Marsh and one core from the Upper Klamath National Wildlife Refuge at the northwest part of Upper Klamath Lake, and may be interrupted by layers of volcanic ash or pumice. The interfaces between varying lithologies are generally gradational but can be sharp. The maximum thickness observed of the basal pond clay is greater than $12 \mathrm{ft}$ and varies from tan to light green with shades of gray found at greater depths. The combined thickness of the overlying clay with peat and peat with clay can range in thickness from 0 to $4 \mathrm{ft}$ and the color of this material is generally tan to light green. This material is overlain by medium to dark brown reed-sedge hemic peat having a thickness ranging from 2 to $14 \mathrm{ft}$. On the surface, a dark brown muck may be found consisting of saturated decomposed organic material that can range in thickness from 0 to $1.5 \mathrm{ft}$. Although the same sequence of materials is generally observed in nearby cores, the lateral continuity of the lithologic layers could not be ascertained owing to the small number of cores collected in each of the undrained wetlands.

No sapric peat was observed in the five cores from the Upper Klamath National Wildlife Refuge at the northwest part of Upper Klamath Lake. As much as $6 \mathrm{ft}$ of dark brown to black sapric peat was found in cores from Shoalwater Bay, Squaw Point, Hanks Marsh, and Wood River Marsh.

Thin clay layers of probable volcanic origin (hereafter referred to as volcanic ash) and pumice sand were observed in cores from the Wood River Marsh, Shoalwater Bay, and Hanks Marsh. The volcanic ash or pumice layers are white to light gray and range in thickness from 0.05 to $0.4 \mathrm{ft}$. Many of the peat materials directly above or below these layers show greater decomposition as indicated by the appearance of dark brown or black hemic peat or the presence of sapric peat. The deposition of volcanic ash may have increased the $\mathrm{pH}$ of the water in the wetlands, creating an environment favorable to microbial activity and resulting in an increased rate of decomposition. Alternatively, the volcanic deposits may have initiated a temporary alteration of the peat-forming vegetation in the wetlands by smothering, mechanical overloading, or chemical attack (Crowley and others, 1994), subsequently reducing the accumulation rate of plant material. These layers of volcanic ash, and pumice sand and gravel might also influence the movement of air and oxygenated water in the subsurface, which could affect decomposition rates. 
Some of the deepest soil cores examined in the undrained wetlands (HNK-01, NWR-A2) contained a smooth gray clay at depths of between about 17 and $22 \mathrm{ft}$ that may be representative of lacustrine deposits during the Pleistocene, when the lake surface of ancient Lake Modoc was about $100 \mathrm{ft}$ higher than present day (see figure $6 \mathrm{E}$ for photograph of similar material in core CAM-08 from a drained wetland). This evidence could place the maximum age of the overlying peat deposits at about 10,000 years, the time when ancient Lake Modoc began to shrink.

Some of the physical and chemical properties of the peat soils of the undrained wetlands relative to the drained wetlands are summarized in figure 7 . The peat soils have a low ash content (median of about 33 percent) and a low bulk density (median of about $0.12 \mathrm{~g} / \mathrm{cm}^{3}$ ) due to the high proportion of organic to inorganic material. The total nitrogen content is high (median of about 2.5 percent). The total phosphorus content (median of about 400 milligrams per kilogram $(\mathrm{mg} / \mathrm{kg})$ is similar to the drained wetlands.

\section{Present-Day Soil Properties of Drained Wetlands}

The occurrence of peat materials in the drained wetlands is similar to that of the undrained wetlands; however, many areas show a greater abundance of decomposed materials, such as sapric or hemic/sapric peat, particularly at or near the surface (fig. 6A-E). Hemic peat ranged in thickness from 0 to $12 \mathrm{ft}$, whereas sapric or hemic/sapric peat materials ranged from 0 to $8 \mathrm{ft}$. A greater abundance and frequency of volcanic ash and pumice was observed in the cores from the Wood River Property. The greater abundance may be due to the wetland's location at the extreme northern end of Upper Klamath Lake and its proximity to the Wood River and other streams that drain the Wood River Valley (which extends northward toward Crater Lake). Volcanic ash or pumice is found in layers from 0.01 to $1.3 \mathrm{ft}$ in thickness. Some areas, such as Algoma and Williamson River North, had considerably more clastic material, such as sand, which may be due to the areas' proximity to the mouths of rivers or small drainage basins, where alluvial deposition can occur.

Correlating specific layers or horizons throughout a drained area can be difficult. Thickness can change over short distances, and horizons (or layers), such as those marked by volcanic ash or pumice, may be absent. This heterogeneity becomes more evident in areas having a greater density of core sites, such as the Wood River Property.
The Ball Bay South drained wetland had about $1.7 \mathrm{ft}$ of organic material mixed with varying quantities of mineral soil and clay at the surface. No soil layers consisting exclusively of peat material were found up to a depth of $4.8 \mathrm{ft}$. It may be that little peat was formed at this location or that the peat which existed has nearly completely decomposed. Due to the lack of data, the Ball Bay South drained wetland was excluded from calculations of present-day or initial nutrient mass or loss.

The effects of decomposition of the peat soils in the drained wetlands are evident in their physical and chemical properties relative to the peat soils of the undrained wetlands (fig. 7). The peat soils of the drained wetlands have a higher ash content (median of about 50 percent) and a higher bulk density (median of about $0.18 \mathrm{~g} / \mathrm{cm}^{3}$ ). Total nitrogen content is lower (median of about 1.7 percent), indicating that some of the nitrogen has been lost from the peat soils. Total phosphorus content (median of about $440 \mathrm{mg} / \mathrm{kg}$ ) is similar to that of the undrained wetlands but has a large range ( 90 to $1,500 \mathrm{mg} / \mathrm{kg}$ ). The large range may be indicative of the occurrence of both phosphorus loss due to drainage and phosphorus accumulation due to adsorption or exchange with adjacent soil layers or ground water, or from agricultural sources such as cattle urine and feces or fertilizer for crops.

Subsidence is a further consequence of the drainage of wetlands. For the Lather muck soil type present in most of the drained wetlands, Cahoon (1985) reports that in the first few years after drainage subsidence can be as much as 10-20 inches and as much as 1 inch per year thereafter. Subsidence reported by land owners ranged from $1 \mathrm{ft}$ to more than $13 \mathrm{ft}$ at the Williamson River North property.

\section{Age of Drained Wetlands}

A chronology of the conversion of wetlands to agricultural use around Upper Klamath Lake was constructed. Present-day and past land owners were interviewed when possible and were the primary source of information. In addition, data from studies by Akins (1970) and Carlson (1993) discuss or identify changes in land use of the wetlands. These sources were supplemented by evaluating the changes in land use as indicated by the addition of dikes and canals or by the land use shown on various maps (Oregon Water Resources Department, 1978; USGS topographic maps and orthophotos at scales of 1:250,000, 1:100,000, 1:62,500, and 1:24,000). 


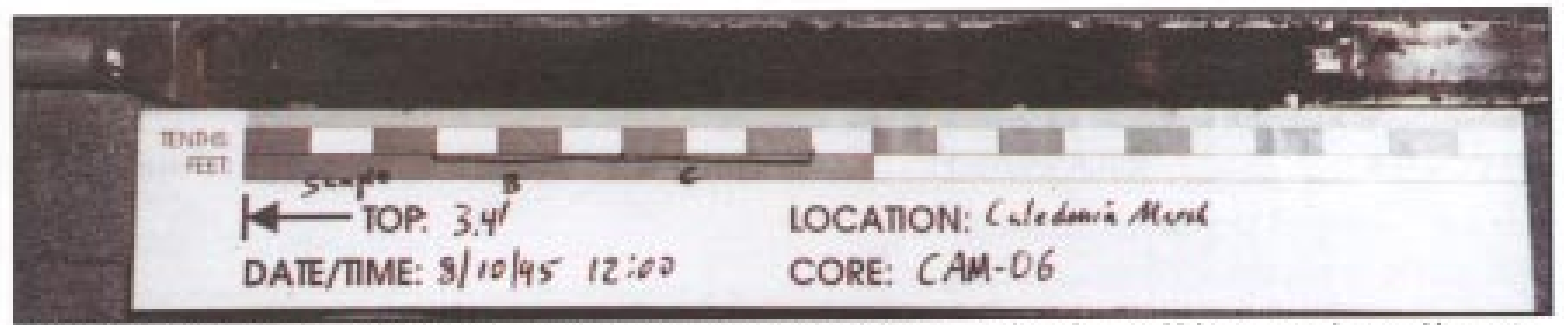

A. Shallow soil layers (depth $=3,4-5.1$ feet), consisting of black fine-grained decomposed sapric peat. Ligh gray pumice sand layer at 4.8 leet may represent deposits trom the climactic enpion of Mount Mazama about 6,900 years ago or reworked depcsits that have subsequently been transported by waler.

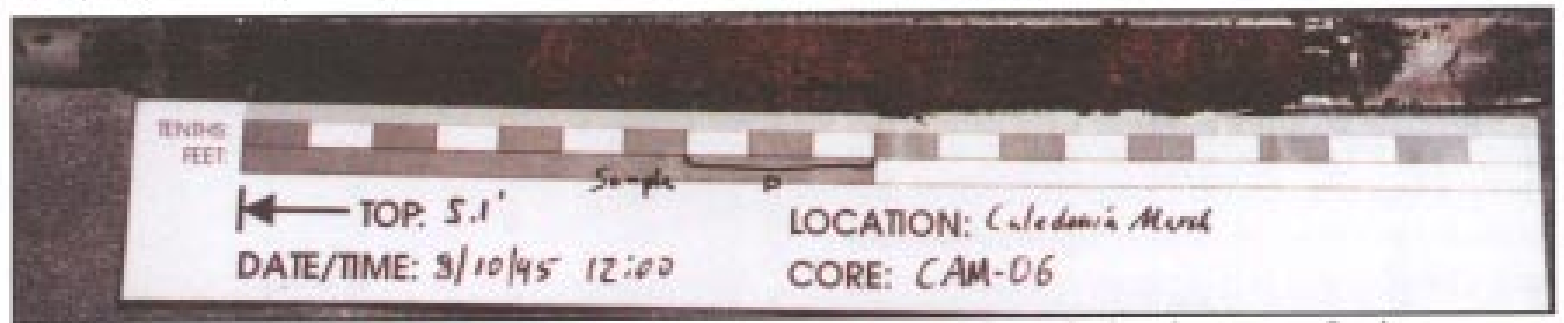

B. Moderately shallow soll layers (depth = 5.1-6.8 leet, showing vansition from bleck fine-grained sapric peat to medum brown coarsegrained hemic peat.

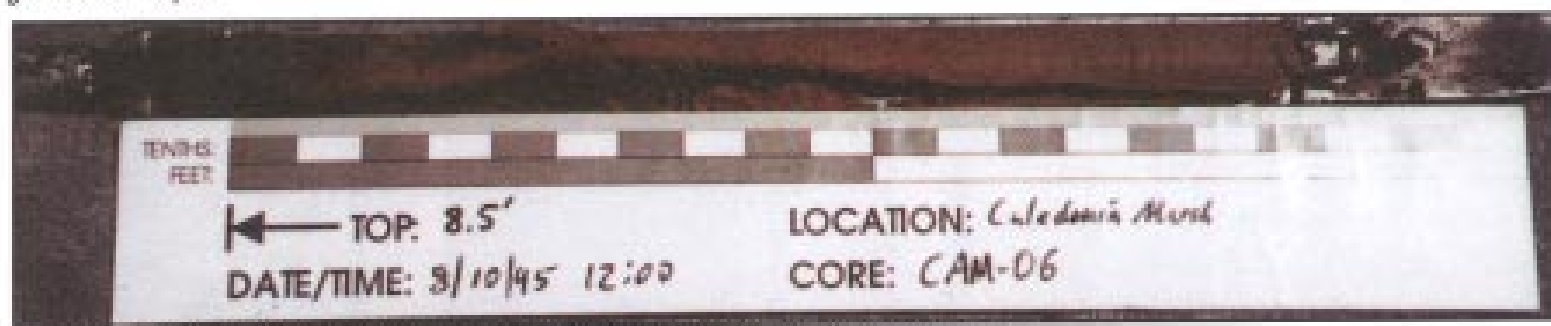

C. Moderately deep soil layers (depth $=8.5-10.2$ feet), showing oive day with hemic peat.

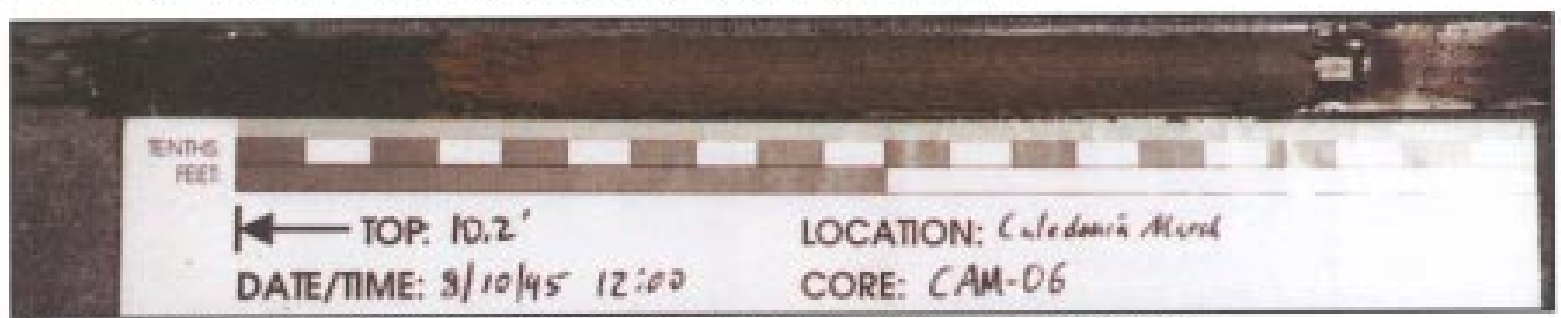

D. Deep sol layers (depth $=10.2-11.9$ leet), showing transition from olve clay with hemic peat to gray clay.

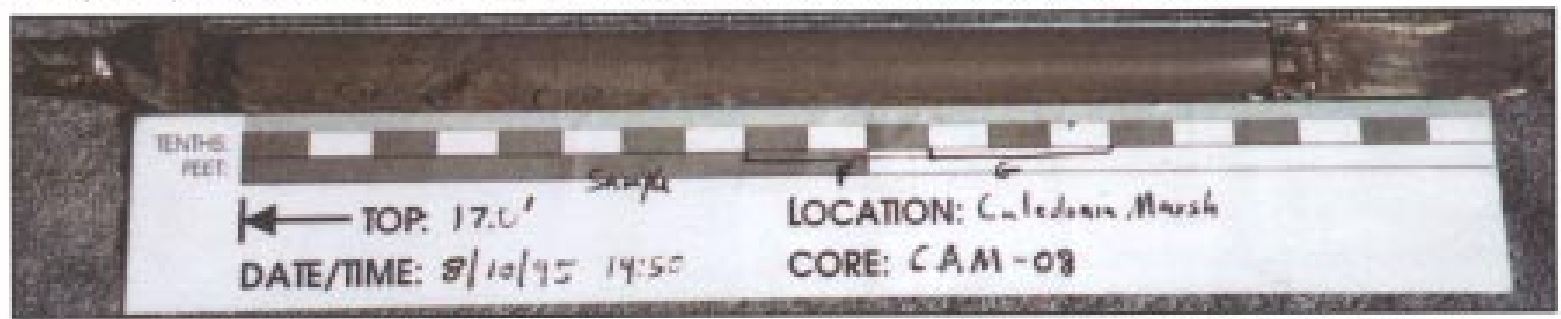

E. Very deep soil layers (depth $=17.0-18.7$ feet), showing smooth gray clay that may be the result of lecustrine deposts during the Pleistocene, when lake level may have been 100 feet higher than the present day.

Figure 6. Examples of soils cores retrieved using Macaulay peat sampler from drained wetland used for cultivation. (Soil depths increase from left to right with depth of top of soil core indicated on placard. Placard is marked in increments of feet and tenths of feet. Core name and sample are indicated on placard. The locations of the cores, summaries of the soil materials, and descriptions of soil samples are presented in Appendixes II and III, and plates 1 and 2.) 

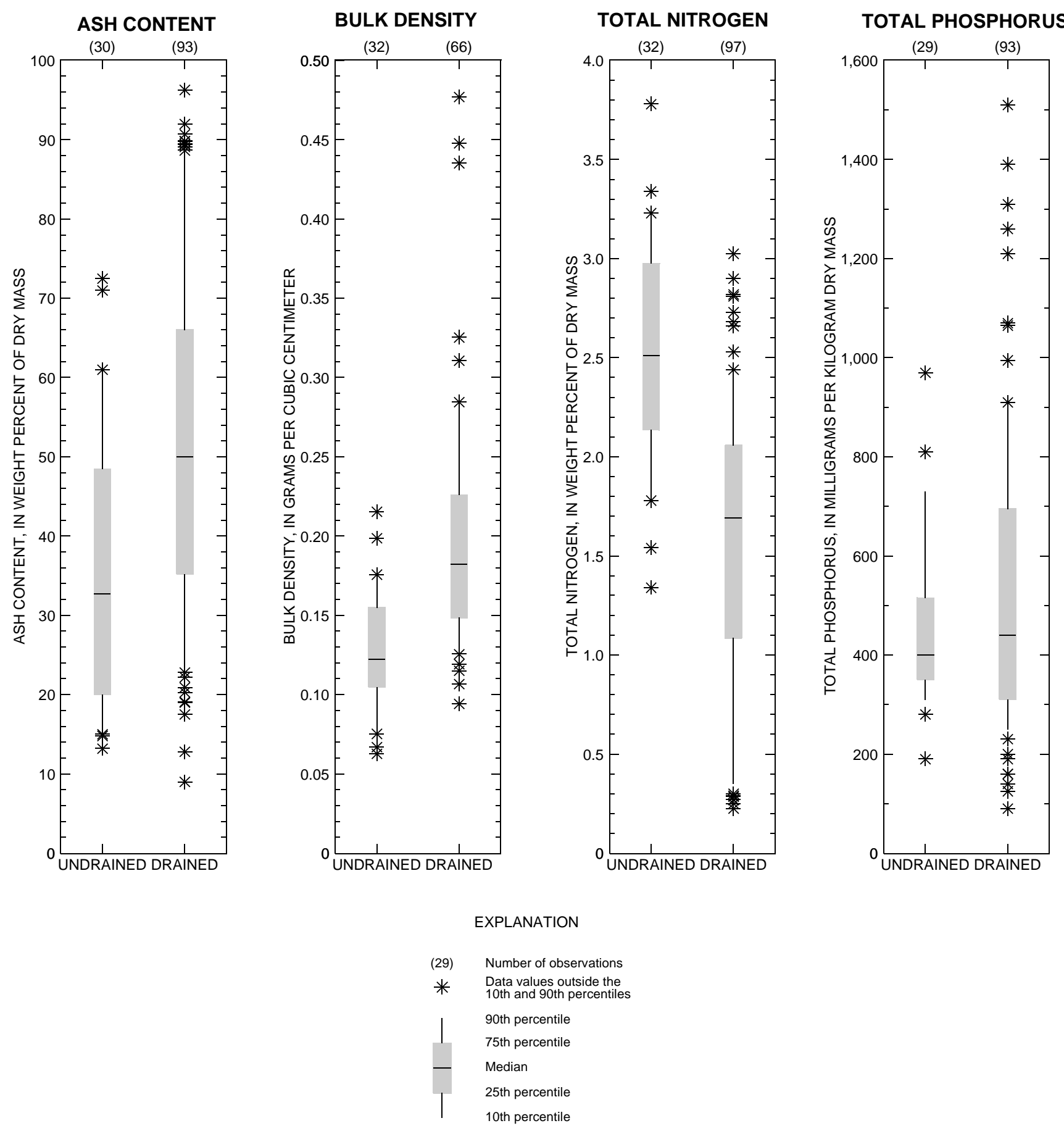

Figure 7. Statistical summaries of physical and chemical properties of samples from undrained and drained peat soils. 
For some areas, only a range of possible dates for the conversion from undrained to drained wetlands could be identified (table 4). For purposes of calculation in this report, the mean date of initial drainage was used. Figure 8 summarizes the relation between the cumulative area of drained wetlands adjacent to Upper Klamath Lake and time.

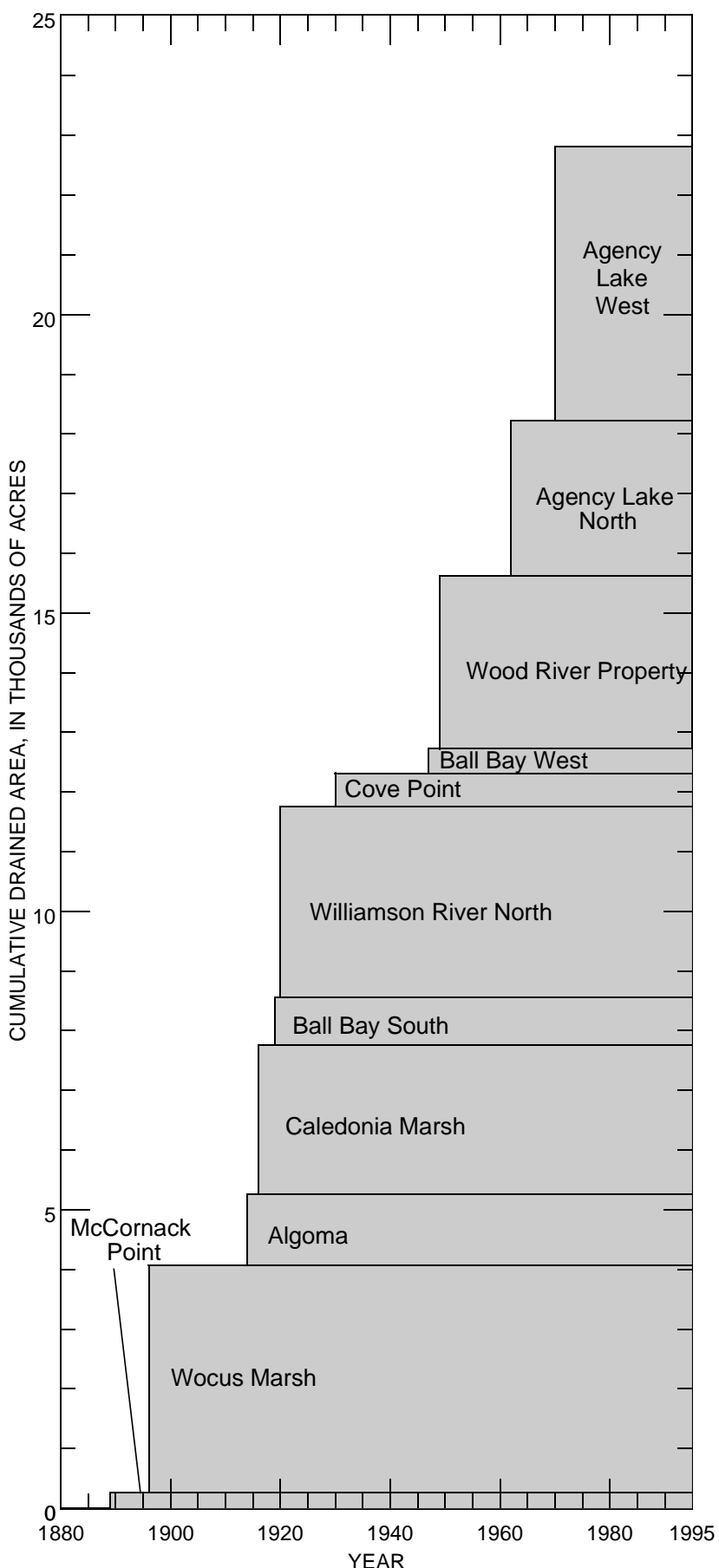

Figure 8. Cumulative area of drained wetlands adjacent to Upper Klamath Lake over time. (This area excludes about 8,200 acres of drained wetlands that were not considered in this study.)

\section{NUTRIENT LOADING FROM DRAINED WETLANDS}

Nutrient loading from drained wetlands was estimated using two independent techniques. The first method involved the measurement of the quantity and quality of water discharged by pumps draining the wetlands. This approach integrates all the nutrient inputs and outputs to the drained wetlands, some of which are a result of the drainage and utilization of the wetlands and some of which are the result of naturally occurring processes. The second method estimated the loss of nutrient mass due to peat decomposition in drained wetlands. Not all the nutrients released by the peat soils were pumped into the lake; some were lost to the atmosphere or incorporated in crops and forage. A comparison of the results from these two techniques is presented to further identify the effects of drainage and agricultural utilization of the wetlands on the nutrient loading of Upper Klamath Lake.

\section{Discussion of Nutrient Loads and Yields from Pump Discharge}

The nutrient concentrations measured at the pumping stations are shown in table 9. These concentrations all fell within the ranges of total nitrogen and total phosphorus given by Miller and Tash (1967) for Upper Klamath Lake and agricultural drains around the lake (table 10). As another comparison, these concentrations are consistent with concentrations reported for Agency Lake in 1990 (Kann, 1993a), to which three of the six pumping stations discharge, either directly or indirectly. Table 10 also shows that the concentrations measured at the flowing artesian wells are elevated in relation to the concentrations measured at the pumping stations.

Instantaneous loads were calculated for the days when the discharge measurements were made (table 11). These instantaneous loads provide a "snapshot" of the nutrient input to the lake for one point in time and are not necessarily representative of the nutrient loading during other time periods. This look at daily nutrient loading is information that cannot be extracted from the annual-loading estimates because of the limitations imposed by the intermittent pumping schedules. The Williamson River North pumping station is noteworthy because the total nitrogen load is greater than the loads from the other five pumping stations combined and the total phosphorus load is about 75 percent of the sum of the other five loads. 
Table 9. Summary of nutrient data from water-quality samples collected at selected pumping stations and flowing artesian wells adjacent to Upper Klamath Lake, Oregon, 1993-95

[All concentrations reported are from filtered-water samples, unless otherwise stated. All concentrations are reported as nitrogen or phosphorus. See table 2 for methods used and minimum reporting levels. $<$, less than]

\begin{tabular}{|c|c|c|c|c|c|c|c|c|c|c|}
\hline \multicolumn{3}{|l|}{ Sample description } & \multicolumn{5}{|c|}{ Nitrogen (milligrams per liter) } & \multicolumn{3}{|c|}{ Phosphorus (milligrams per liter) } \\
\hline Station name & Date & Time & Ammonia & $\begin{array}{c}\text { Ammonia } \\
\text { plus } \\
\text { organic } \\
\text { nitrogen }\end{array}$ & $\begin{array}{l}\text { Ammonia } \\
\text { plus } \\
\text { organic } \\
\text { nitrogen, } \\
\text { unfiltered }\end{array}$ & Nitrite & $\begin{array}{c}\text { Nitrite } \\
\text { plus } \\
\text { nitrate }\end{array}$ & $\begin{array}{c}\text { Phosphorus, } \\
\text { unfiltered }\end{array}$ & Phosphorus & Orthophosphate \\
\hline
\end{tabular}

Wocus Marsh
Wocus Marsh
Wocus Marsh
Wocus Marsh
Wocus Marsh
Wocus Marsh
Wocus Marsh

$\boldsymbol{\omega} \quad$ Wocus Marsh

East Caledonia Marsh

East Caledonia Marsh

East Caledonia Marsh

Williamson River North

Williamson River North

Williamson River North

Williamson River North

Williamson River North

Williamson River North

Williamson River North

Williamson River North

Williamson River North

Northwest Agency Lake

Northwest Agency Lake

Northwest Agency Lake

Pumping stations

\begin{tabular}{|c|c|c|c|c|c|c|c|c|c|}
\hline 04-07-93 & 1245 & 0.15 & $<0.2$ & 3.3 & 0.01 & 0.16 & 0.17 & $<0.01$ & 0.04 \\
\hline 05-14-93 & 0915 & .07 & 2.6 & 3.7 & $<.01$ & .028 & .28 & .16 & .10 \\
\hline 04-06-94 & 0900 & .60 & 4.6 & 6.2 & .03 & .012 & .29 & .14 & .12 \\
\hline 04-20-94 & 1000 & .13 & 2.9 & 4.8 & .02 & .010 & .31 & .05 & .03 \\
\hline 05-05-94 & 0920 & .08 & 2.2 & 3.3 & $<.01$ & .012 & .32 & .11 & .10 \\
\hline 05-24-94 & 1145 & .08 & 2.1 & 2.9 & $<.01$ & .007 & .21 & .10 & .07 \\
\hline 03-16-95 & 1340 & .15 & 4.0 & 4.3 & .02 & .41 & .10 & .06 & .02 \\
\hline 04-04-95 & 0830 & .03 & 4.1 & 4.5 & $<.01$ & $<.005$ & .11 & .04 & .02 \\
\hline 04-19-95 & 0830 & .14 & 4.4 & 4.8 & $<.01$ & .029 & .08 & .05 & .01 \\
\hline 04-07-93 & 1710 & .16 & 2.2 & 2.9 & .01 & .094 & .14 & .05 & .02 \\
\hline 05-14-93 & 1930 & .29 & 3.4 & 4.1 & .02 & .084 & .15 & .10 & .07 \\
\hline 05-05-94 & 1130 & .05 & 3.9 & 5.5 & $<.01$ & .008 & .44 & .15 & .15 \\
\hline 04-08-93 & 1315 & .83 & 1.9 & 2.3 & .03 & .32 & .57 & .45 & .39 \\
\hline 04-06-94 & 1345 & 2.7 & 3.5 & 3.9 & .03 & .040 & 1.4 & .91 & .93 \\
\hline 04-20-94 & 1300 & 2.0 & 2.3 & 2.8 & .01 & .033 & 1.7 & 1.2 & 1.2 \\
\hline 05-06-94 & 0845 & 4.3 & 5.2 & 6.2 & $<.01$ & .066 & 1.2 & .71 & .75 \\
\hline 03-15-95 & 1530 & 1.5 & 2.7 & 2.7 & .02 & .43 & .70 & .50 & .49 \\
\hline 04-04-95 & 1100 & 1.6 & 3.4 & 3.9 & .02 & .11 & 1.0 & .80 & .64 \\
\hline 04-19-95 & 1140 & 2.6 & 3.8 & 4.4 & .02 & .15 & .92 & .52 & .50 \\
\hline 05-24-95 & 0815 & 2.9 & 3.7 & 3.6 & .02 & .046 & .85 & .75 & .77 \\
\hline 08-17-95 & 1330 & 1.1 & 1.8 & 1.8 & .07 & .30 & .89 & .80 & .77 \\
\hline 04-08-93 & 1620 & .04 & 1.1 & 1.5 & $<.01$ & $<.005$ & .21 & .15 & .10 \\
\hline 05-14-93 & 1645 & .03 & 1.3 & 2.5 & $<.01$ & $<.005$ & .39 & .20 & 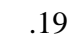 \\
\hline 04-06-94 & 1530 & .67 & 2.4 & 3.9 & .04 & .051 & .58 & .41 & \\
\hline
\end{tabular}


Table 9. Summary of nutrient data from water-quality samples collected at selected pumping stations and flowing artesian wells adjacent to Upper Klamath Lake, Oregon, 1993-95-Continued

\begin{tabular}{|c|c|c|c|c|c|c|c|c|c|c|}
\hline \multicolumn{3}{|l|}{ Sample description } & \multicolumn{5}{|c|}{ Nitrogen (milligrams per liter) } & \multicolumn{3}{|c|}{ Phosphorus (milligrams per liter) } \\
\hline Station name & Date & Time & Ammonia & $\begin{array}{c}\text { Ammonia } \\
\text { plus } \\
\text { organic } \\
\text { nitrogen }\end{array}$ & $\begin{array}{l}\text { Ammonia } \\
\text { plus } \\
\text { organic } \\
\text { nitrogen, } \\
\text { unfiltered }\end{array}$ & Nitrite & $\begin{array}{l}\text { Nitrite } \\
\text { plus } \\
\text { nitrate }\end{array}$ & $\begin{array}{l}\text { Phosphorus, } \\
\text { unfiltered }\end{array}$ & Phosphorus & Orthophosphate \\
\hline
\end{tabular}

Northwest Agency Lake

Northwest Agency Lake

Northwest Agency Lake

Northwest Agency Lake

Northwest Agency Lake

\begin{tabular}{|c|c|c|c|c|c|c|c|c|c|c|}
\hline Northwest Agency Lake & 05-06-94 & 1240 & $<0.01$ & 0.4 & 0.6 & $<0.01$ & 0.005 & 0.21 & 0.13 & 0.14 \\
\hline Northwest Agency Lake & $03-16-95$ & 0930 & .05 & 1.1 & 1.2 & $<.01$ & $<.005$ & .13 & .10 & .08 \\
\hline Northwest Agency Lake & 04-04-95 & 1400 & .02 & .4 & .5 & $<.01$ & $<.005$ & .07 & .05 & .04 \\
\hline Northwest Agency Lake & 04-19-95 & 1330 & .42 & 2.2 & 2.6 & .01 & .033 & .30 & .22 & .19 \\
\hline Northwest Agency Lake & $05-24-95$ & 1500 & .03 & .4 & .5 & $<.01$ & $<.005$ & .11 & .09 & .09 \\
\hline Wood River Property (Seven Mile Canal) & $04-06-93$ & 0950 & .12 & 2.0 & 2.5 & .02 & .17 & .56 & .52 & .40 \\
\hline Wood River Property (Seven Mile Canal) & $05-14-93$ & 1545 & .04 & 2.4 & 3.0 & $<.01$ & .052 & .75 & 63 & .55 \\
\hline Wood River Property (Seven Mile Canal) & 04-07-94 & 0830 & .23 & 1.9 & 2.8 & .03 & .016 & 1.2 & 1.0 & .96 \\
\hline Wood River Property (Seven Mile Canal) & 04-13-94 & 1345 & .67 & 3.4 & 4.8 & .03 & .025 & 1.1 & .87 & .76 \\
\hline Wood River Property (Seven Mile Canal) & 05-06-94 & 1420 & 1.3 & 3.5 & 3.9 & .02 & .058 & 1.2 & 1.0 & .96 \\
\hline Wood River Property (Seven Mile Canal) & $06-23-95$ & 1215 & .05 & 2.4 & 2.6 & .02 & $<.005$ & .79 & .75 & .70 \\
\hline Wood River Property (Corral) & $04-06-93$ & 1255 & .04 & 2.1 & 2.2 & $<.01$ & .006 & .76 & .68 & .55 \\
\hline Wood River Property (Corral) & $05-14-93$ & 1430 & .21 & 2.4 & 3.4 & $<.01$ & .037 & 1.0 & .78 & .76 \\
\hline Wood River Property (Corral) & 04-07-94 & 1410 & .27 & 3.0 & 4.4 & .04 & .022 & 1.6 & 1.3 & 1.3 \\
\hline Wood River Property (Corral) & $05-05-94$ & 1540 & .15 & 1.0 & 1.0 & $<.01$ & .013 & .53 & .39 & .36 \\
\hline Wood River Property (Corral) & $05-24-95$ & 1245 & .17 & 2.2 & 2.3 & .07 & .12 & .99 & .96 & .97 \\
\hline Wood River Property (Corral) & $06-23-95$ & 1330 & $<.015$ & 2.2 & 2.9 & .02 & $<.005$ & 1.0 & .82 & .82 \\
\hline \multicolumn{11}{|c|}{ Flowing artesian wells } \\
\hline Flowing artesian well \#1 & $07-13-93$ & 0830 & 5.5 & 5.8 & 6.0 & $<.01$ & $<.005$ & 6.4 & 6.7 & 6.2 \\
\hline Flowing artesian well \#1 & 04-07-94 & 1215 & 5.5 & 6.3 & 7.0 & .03 & $<.005$ & 7.3 & 6.5 & 6.8 \\
\hline Flowing artesian well \#1 & $05-24-95$ & 1045 & 5.7 & 5.7 & 5.6 & $<.01$ & $<.005$ & 6.4 & 6.8 & 6.6 \\
\hline Flowing artesian well \#2 & $05-24-95$ & 1410 & 7.8 & 8.7 & 8.7 & $<.01$ & $<.005$ & 2.0 & 1.9 & 1.7 \\
\hline Flowing artesian well \#3 & $08-17-95$ & 1100 & 6.1 & 7.1 & 7.0 & $<.01$ & $<.005$ & 7.2 & 7.5 & 7.1 \\
\hline
\end{tabular}

Pumping stations-Continued

08-17-95 1100 
Table 10. Concentration ranges of total nitrogen and total phosphorus from the Upper Klamath Lake area, Oregon [mg/L, milligrams per liter]

\begin{tabular}{|c|c|c|c|}
\hline Water source & $\begin{array}{l}\text { Total nitrogen } \\
\text { concentrations }\end{array}$ & $\begin{array}{l}\text { Total phosphorus } \\
\text { concentrations }\end{array}$ & Reference \\
\hline Upper Klamath Lake & 0.0 to $10.6 \mathrm{mg} / \mathrm{L}$ & 0.03 to $2.0 \mathrm{mg} / \mathrm{L}$ & Miller and Tash, 1967 \\
\hline Agricultural drains around Upper Klamath Lake & 0.0 to $8.8 \mathrm{mg} / \mathrm{L}$ & 0.08 to $2.0 \mathrm{mg} / \mathrm{L}$ & Miller and Tash, 1967 \\
\hline Agency Lake & 0.3 to $8.8 \mathrm{mg} / \mathrm{L}$ & 0.06 to $0.65 \mathrm{mg} / \mathrm{L}$ & Kann, 1993a \\
\hline Wetland pumping stations & 0.5 to $6.3 \mathrm{mg} / \mathrm{L}$ & 0.07 to $1.7 \mathrm{mg} / \mathrm{L}$ & This study \\
\hline Flowing artesian wells on Wood River Property & 5.6 to $8.7 \mathrm{mg} / \mathrm{L}$ & 2.0 to $7.3 \mathrm{mg} / \mathrm{L}$ & This study \\
\hline
\end{tabular}

Table 11. Instantaneous loads for pumping stations adjacent to Upper Klamath Lake, Oregon, May 5-6, 1994

[Total nitrogen, ammonia plus organic nitrogen in unfiltered water plus nitrite plus nitrate in filtered water; total phosphorus, phosphorus in unfiltered water; lbs/day, pounds per day; see table 9 for concentrations and table 3 for discharge values]

\begin{tabular}{lccc}
\hline & Date & $\begin{array}{c}\text { Total } \\
\text { nitrogen } \\
\text { load } \\
\text { (Ibs/day) }\end{array}$ & $\begin{array}{c}\text { Total } \\
\text { phosphorus } \\
\text { load } \\
\text { (lbs/day) }\end{array}$ \\
\hline Pumping station & Wocus Marsh & & \\
East Caledonia Marsh & $05-05-94$ & 280 & 27 \\
Williamson River North & $05-06-94$ & 880 & 170 \\
$\begin{array}{l}\text { Northwest Agency Lake } \\
\text { Wood River Property }\end{array}$ & $05-06-94$ & 330 & 110 \\
$\quad$ (Seven Mile Canal) & $105-05-94$ & 92 & 28 \\
$\begin{array}{l}\text { Wood River Property } \\
\text { (Corral) }\end{array}$ & & 79 & 41 \\
& & &
\end{tabular}

${ }^{1}$ Water-quality samples collected 05-05-94, but discharge measured 05-06-94.

This most likely is due to the elevated concentrations measured at this pumping station on May 6, 1994 (table 9). Although the instantaneous loads for the Williamson River North pumping station are large in relation to the other stations (table 11), the annual loads are comparable to those of the other stations (fig. 9).

Miller and Tash (1967, p. 9), in their nutrient budget for Upper Klamath Lake from March 1965 to April 1966, estimate the total input from agricultural drains for five drained wetlands to be 241 tons of nitrogen and 133 tons of total phosphorus over the 14-month study. These values are about 3 and 9 times, respectively, larger than the sum of the annual loads of nitrogen and phosphorus calculated for each of the pumping stations in 1995 (80 tons and 15 tons, respectively) (fig. 9). It is not surprising that these values would differ because Miller and Tash considered a larger number of drained areas than the present study, and their study encompassed a 14-month, instead of a 12-month, period.

When comparing the annual median concentrations, volume of water pumped, loads, and yields among pumping stations for total nitrogen, the Northwest Agency Lake pumping station stands out (fig. 9). Although the concentration is much lower than those of the other stations, the volume of water pumped is much larger due to the area and the 600-horsepower pumping station (which is greater than the horsepower for the other five pumping stations combined). Thus, the load is larger. When normalized for the drained area, however, the yield is actually the smallest for all of the pumping stations in 1995 because of the large area drained. Additionally, there is little variation in the total nitrogen yields among sites for a given year or among years for a given site.

There was, however, much more variation among sites for the annual total phosphorus yields (fig. 9). Wocus Marsh and Northwest Agency Lake pumping stations had median total phosphorus concentrations that were more than four times smaller than the median concentrations for the Williamson River North and Wood River Property pumping stations. This same pattern was repeated in the load and yield values for Wocus Marsh. For the Northwest Agency Lake pumping station, however, the load was in the same range as the other two stations because the volume of water pumped was so large. Wood River Property total phosphorus concentrations, loads, and yields may be larger due to ground-water inputs as indicated by the high concentrations of phosphorus in the samples from the flowing artesian wells (table 9). One possible reason why the Williamson River North pumping station has higher total phosphorus concentrations could be from fertilizers applied to the cultivated crops grown in the drained area. 
Total nitrogen
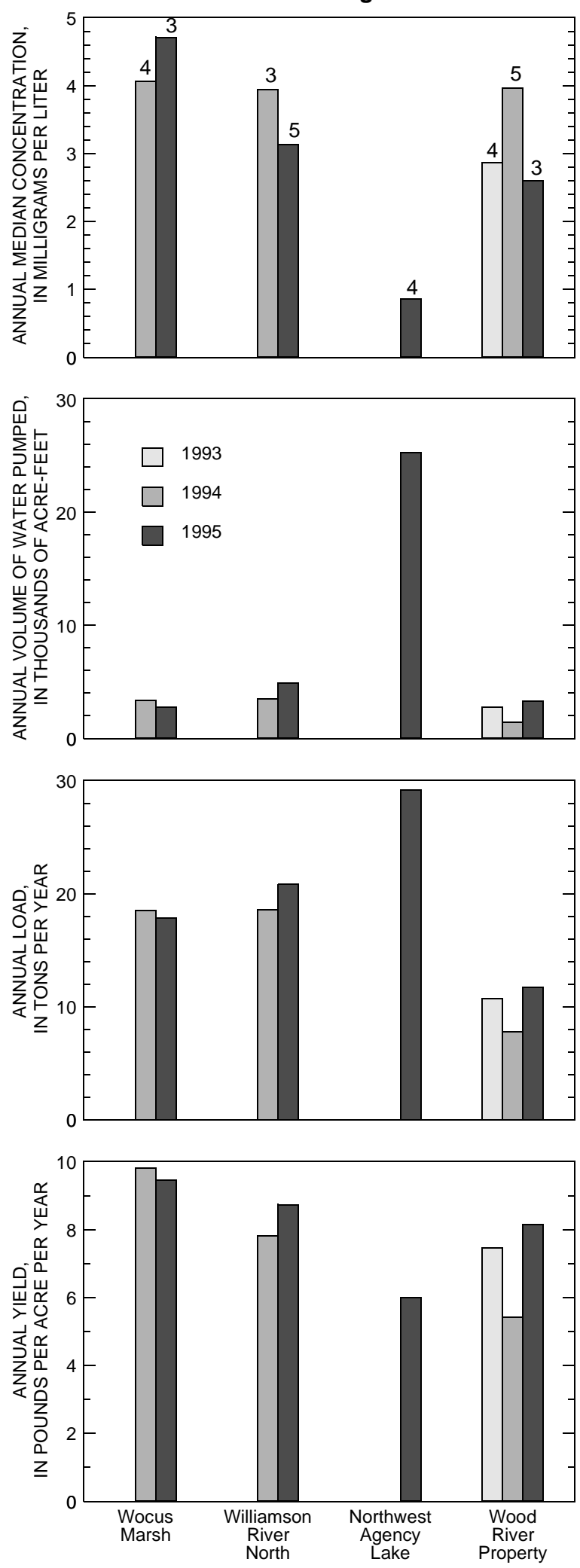

Total phosphorus
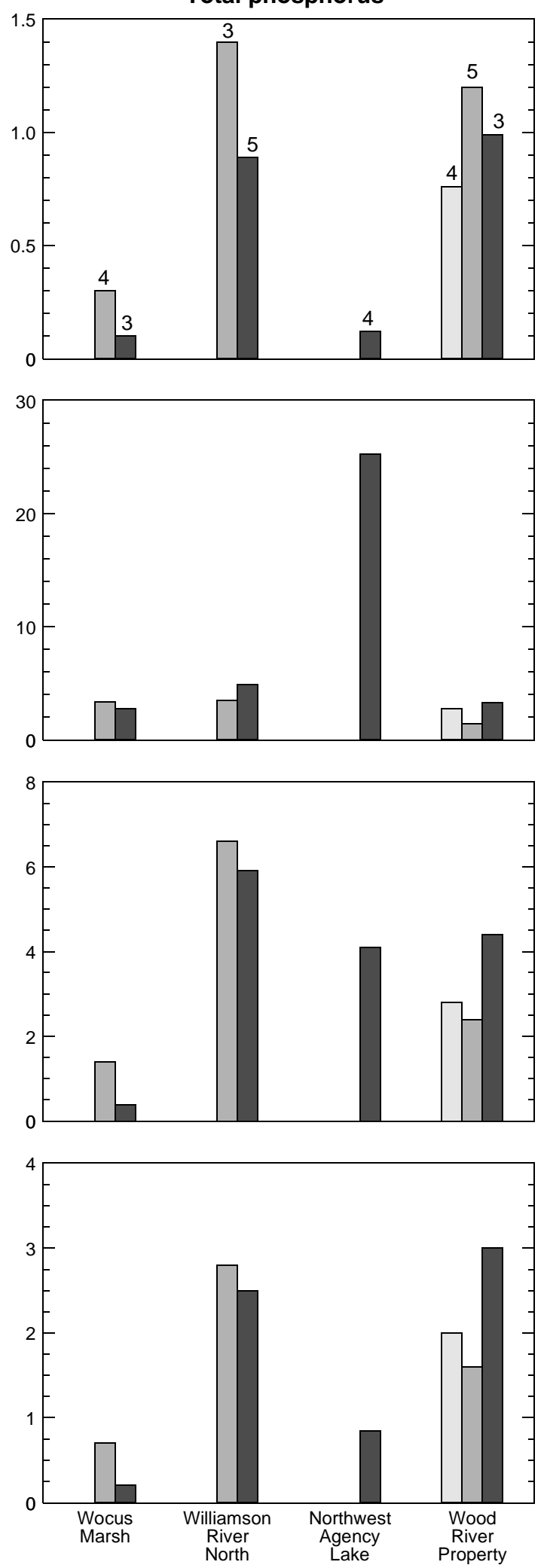

Figure 9. Annual median concentrations, volume of water pumped, load, and yield of total nitrogen and total phosphorus for selected pumping stations adjacent to Upper Klamath Lake, Oregon, 1993-95 water years. (Number over bar indicates the number of determinations used in the calculation of the median.) 


\section{Implications of Nutrient Loading from Ground Water}

Three flowing artesian wells on the Wood River Property (fig. 2) were sampled during this study in an attempt to estimate nutrient loading from ground water. These wells flow continuously onto the land surface and were used for watering livestock. The occurrence of artesian conditions for these wells is probably the result of confining units consisting of the alluvial fill materials in the Wood River Valley. Newcomb and Hart (1958) located more than 20 wells between Fort Klamath and the Wood River Property that were all completed in artesian aquifers and that ranged in depth from 90 to $360 \mathrm{ft}$ having heads as much as $20 \mathrm{ft}$ above the land surface. The three wells sampled in this study are probably similar to the wells located by Newcomb and Hart. Because Upper Klamath Lake and the adjacent drained wetlands, including the Wood River Property, form the lowest part of the Upper Klamath Basin, these areas are expected to be the discharge area for the regional ground-water flow system in the Upper Klamath Lake basin. As a result, the water flowing from the artesian wells is probably from the regional ground-water flow system and is assumed to have little variation in concentration or discharge over the period 1993-95.

Nutrient loads for these three flowing artesian wells were calculated in the same general way as for the pumping stations. The median concentrations measured at the flowing artesian wells in the Wood River Property area and the estimated annual loads are given in table 12. The wells represent an annual (1995) total load that could account for 1 and 3 percent of the total nitrogen and phosphorus loads, respectively, from the Wood River Property area for the 1995 water year. Although this contribution is small, it does indicate that total nutrient loading to Upper Klamath Lake from the discharge of ground water could be significant. Further study of the quantity and nutrient concentration of discharge from regional ground-water flow system is needed to quantify the nutrient loading to Upper Klamath Lake and the adjacent wetlands.

\section{Discussion of Nutrient Loss and Yields from Peat Soils}

The loss of nutrients from the drained wetlands was calculated as the change in nutrient mass during several 1-year periods and as the cumulative loss since drainage. About 26 percent $(8,200$ acres) of the drained wetlands adjacent to Upper Klamath Lake were not sampled as part of this study and, therefore, are not included in these calculations. Differences in the time since drainage began, the frequency and duration of flooding, land use, and cultivation practices prohibited extrapolating from sampled drained wetlands that were near these unsampled wetlands. In addition, the Ball Bay South drained wetland (800 acres) is also not included in the above totals owing to the lack of data.

On an annual basis for the 1994-95 period, the estimated TN mass loss ranged from about 4 to 860 tons and totaled 3,000 tons for all drained wetlands that were sampled (table 13). During this period the estimated TP mass loss ranged from about 0 to 21 tons and totaled 60 tons for all drained wetlands that were sampled (table 13). The Williamson River North and the Agency Lake North drained wetlands had the largest annual loss of TN and TP mass during 1994-95.

Table 12. Estimated discharge, nutrient concentrations, and annual loads for flowing artesian wells adjacent to Upper Klamath Lake, Oregon, 1993-95

[Total nitrogen, ammonia plus organic nitrogen in unfiltered water plus nitrite plus nitrate in filtered water; total phosphorus, phosphorus in unfiltered water; $\mathrm{ft}^{3} / \mathrm{s}$, cubic feet per second; mg/L, milligrams per liter; see figure 2 for location of flowing artesian wells]

\begin{tabular}{|c|c|c|c|c|c|c|}
\hline \multirow[b]{2}{*}{$\begin{array}{c}\text { Well } \\
\text { number }\end{array}$} & \multirow[b]{2}{*}{ Date } & \multirow{2}{*}{$\begin{array}{l}\text { Estimated } \\
\text { discharge } \\
\left(10^{-3} \mathrm{ft}^{3} / \mathrm{s}\right)\end{array}$} & \multicolumn{2}{|c|}{ Total nitrogen } & \multicolumn{2}{|c|}{ Total phosphorus } \\
\hline & & & $\begin{array}{c}\text { Concentration } \\
(\mathrm{mg} / \mathrm{L})\end{array}$ & $\begin{array}{c}\text { Annual load } \\
\text { (pounds) }\end{array}$ & $\begin{array}{c}\text { Concentration } \\
(\mathrm{mg} / \mathrm{L})\end{array}$ & $\begin{array}{c}\text { Annual load } \\
\text { (pounds) }\end{array}$ \\
\hline 1 & $07-13-93$ & 6.3 & 6.0 & 75 & 6.4 & 80 \\
\hline 1 & 04-07-94 & 6.3 & 7.0 & 88 & 7.3 & 91 \\
\hline 1 & 05-24-95 & 6.3 & 5.6 & 68 & 6.4 & 79 \\
\hline 2 & $05-24-95$ & 5.8 & 8.7 & 99 & 2.0 & 22 \\
\hline 3 & 08-17-95 & 13 & 7.0 & 176 & 7.2 & 181 \\
\hline
\end{tabular}


Table 13. Parameters and estimates for estimation of annual loss and yield of total nitrogen and total phosphorus from drained areas using a first-order rate law [See section "Calculation of Decay Rates and Annual Estimates of Peat and Nutrient Loss" for method of calculation. Symbols in brackets refer to variables used in the equation of the first-order rate law. Values for individual drained wetlands are presented using two significant figures. Sums were calculated using masses for individual areas are rounded to the nearest 10,000 and 100 tons for initial mass and annual loss, respectively, for total nitrogen, and 100 and 1 tons for initial mass and annual loss, respectively, for total phosphorus. Initial mass, mass prior to drainage of a wetland for agricultural use; mass, in tons; yield, in pounds per acre; --, not applicable]

\begin{tabular}{|c|c|c|c|c|c|c|c|c|c|c|c|c|}
\hline \multirow[b]{2}{*}{ Drained wetland } & \multirow{2}{*}{$\begin{array}{c}\text { Area } \\
\text { (acres) }\end{array}$} & \multirow{2}{*}{$\begin{array}{c}\text { Year } \\
\text { drained }^{1}\end{array}$} & \multirow{2}{*}{$\begin{array}{c}\text { Rate } \\
\text { constant }^{2} \\
{[\mathrm{k}]} \\
\text { (percent } \\
\text { per year) }\end{array}$} & \multirow{2}{*}{$\begin{array}{c}\text { Initial } \\
\text { mass } \\
{[\mathrm{A}]} \\
\text { (tons) }\end{array}$} & \multicolumn{4}{|c|}{$\begin{array}{c}\text { Annual loss } \\
\text { (tons) }\end{array}$} & \multicolumn{4}{|c|}{$\begin{array}{l}\text { Annual yield } \\
\text { (pounds/acre) }\end{array}$} \\
\hline & & & & & $1965-66$ & $1992-93$ & $1993-94$ & $1994-95$ & $1965-66$ & $1992-93$ & $1993-94$ & 1994-95 \\
\hline \multicolumn{13}{|c|}{ TOTAL NITROGEN } \\
\hline \multicolumn{13}{|c|}{ Land use-crop cultivation } \\
\hline McCornack Point & 260 & 1889 & 2.38 & 1,800 & 7.1 & 3.7 & 3.6 & 3.5 & 54 & 28 & 28 & 27 \\
\hline Algoma & 1,200 & 1914 & 1.67 & 20,000 & 140 & 91 & 89 & 88 & 240 & 150 & 150 & 150 \\
\hline Caledonia Marsh & 2,500 & 1916 & .46 & 82,000 & 310 & 270 & 270 & 270 & 250 & 220 & 220 & 220 \\
\hline Williamson River North & 3,200 & 1920 & 1.32 & 170,000 & 1,300 & 880 & 870 & 860 & 780 & 550 & 540 & 540 \\
\hline Cove Point & 550 & $1919-40$ & 1.63 & 15,000 & 130 & 86 & 85 & 83 & 490 & 310 & 310 & 300 \\
\hline \multicolumn{13}{|c|}{ Land use-crop cultivation and cattle grazing } \\
\hline Wocus Marsh & 3,800 & 1896 & .63 & 86,000 & 350 & 300 & 290 & 290 & 190 & 160 & 160 & 160 \\
\hline \multicolumn{13}{|c|}{ Land use-cattle grazing } \\
\hline Ball Bay West & 410 & $1946-47$ & .13 & 6,100 & 7.8 & 7.5 & 7.5 & 7.5 & 38 & 36 & 36 & 36 \\
\hline Wood River Property & 2,900 & $1940-57$ & .75 & 88,000 & 580 & 470 & 470 & 470 & 400 & 330 & 330 & 330 \\
\hline Agency Lake North & 2,600 & 1962 & .55 & 130,000 & 710 & 610 & 610 & 600 & 550 & 470 & 470 & 470 \\
\hline Agency Lake West & 4,600 & $1968-71$ & .11 & 210,000 & (3) -- & 230 & 230 & 230 & (3) -- & 100 & 100 & 100 \\
\hline Total & 22,020 & -- & -- & 820,000 & 3,500 & 3,000 & 3,000 & 3,000 & -- & -- & -- & -- \\
\hline \multicolumn{13}{|c|}{ TOTAL PHOSPHORUS } \\
\hline \multicolumn{13}{|c|}{ Land use-crop cultivation } \\
\hline McCornack Point & 260 & 1889 & .951 & 50 & .22 & .17 & .17 & .17 & 1.7 & 1.3 & 1.3 & 1.3 \\
\hline Algoma & 1,200 & 1914 & .166 & 610 & .93 & .89 & .89 & .89 & 1.5 & 1.5 & 1.5 & 1.5 \\
\hline Caledonia Marsh & 2,500 & 1916 & .291 & 2,000 & 5.0 & 4.6 & 4.6 & 4.6 & 4.0 & 3.7 & 3.7 & 3.7 \\
\hline Williamson River North & 3,200 & 1920 & .702 & 5,000 & 25 & 21 & 21 & 21 & 16 & 13 & 13 & 13 \\
\hline Cove Point & 550 & $1919-40$ & .796 & 430 & 2.6 & 2.1 & 2.1 & 2.0 & 9.4 & 7.5 & 7.5 & 7.4 \\
\hline \multicolumn{13}{|c|}{ Land use-crop cultivation and cattle grazing } \\
\hline Wocus Marsh & 3,800 & 1896 & .054 & 2,700 & 1.4 & 1.4 & 1.4 & 1.4 & .74 & .73 & .72 & .72 \\
\hline \multicolumn{13}{|c|}{ Land use-cattle grazing } \\
\hline Ball Bay West & 410 & $1946-47$ & .055 & 160 & .086 & .084 & .084 & .084 & .41 & .41 & .41 & .41 \\
\hline Wood River Property & 2,900 & $1940-57$ & .641 & 2,100 & 12 & 10 & 10 & 10 & 8.3 & 7.0 & 7.0 & 6.9 \\
\hline Agency Lake North & 2,600 & 1962 & .981 & 2,700 & 26 & 20 & 20 & 20 & 20 & 15 & 15 & 15 \\
\hline Agency Lake West & 4,600 & $1968-71$ & 0 & 3,400 & (3) & 0 & 0 & 0 & (3) & 0 & 0 & 0 \\
\hline Total & 22,020 & -- & -- & 19,200 & 73 & 60 & 60 & 60 & -- & -- & -- & -- \\
\hline
\end{tabular}

${ }^{1}$ If the year drained is only known as a range, then the mean was used in determining the time since drainage for use in the first-order rate law equation.

${ }^{2}$ The rate constant, as presented in the table, is expressed as a percentage and must be divided by 100 before use in the first-order rate law equation.

${ }^{3}$ Area not yet drained during this period. 
McCornack Point and Ball Bay West had the smallest annual loss of TN mass and Agency Lake West and Ball Bay West had the smallest annual loss of TP mass. A comparison of the estimated annual yields of $\mathrm{TN}$ and TP is useful in removing the influence of the areal size of the drained wetland and shows no apparent trends with regard to land use or the time since drainage (table 13, figs. 10A and 11 A).

The total cumulative nutrient loss from the drained wetlands was calculated as the sum of the cumulative nutrient losses from each drained wetland where soil samples were collected (table 14). Since being drained, the peat soils of the drained wetlands are estimated to have cumulatively lost 250,000 tons and 4,300 tons of TN and TP, respectively. Using table 14, comparisons can be made of the cumulative mass of peat, TN, and TP lost from the individual drained wetlands. The drained wetland that has the largest cumulative loss of peat, TN, and TP since being drained is the Williamson River North area which has lost more than twice the mass of these constituents than any other drained wetland. The Agency Lake West and Ball Bay West drained wetlands have had little or no cumulative loss of peat, TN, or TP mass since being drained.

Estimated yields of cumulative mass lost for peat, TN, and TP are presented in table 14 and figures 10B and 11B. The Williamson River North drained wetland has the largest cumulative loss of peat, TN, and TP per unit area, nearly twice that of any other drained wetland. There appears to be a relation between land use and the cumulative losses of peat and TN per unit area (table 14, fig. 10B). The cumulative loss of peat and TN per unit area for drained wetlands used for cultivation of crops are larger than for wetlands used for the grazing of cattle. The cumulative loss of TP per unit area does not show this relation (fig. 11B). However, these comparisons do not account for the differences due to the length of time since drainage and variations in the initial mass of peat, TN, and TP. Comparison of the drained wetlands using the relation between the amount of time elapsed since drainage began and the percentage of initial TN or TP mass still present can help to account for the differences in the initial mass of peat, TN, or TP. Land use, time since drainage, or both appear to be correlated to the cumulative TN loss; however, this is not evident for TP (figs. 10C and 11C). The cumulative $\mathrm{TN}$ loss as a percentage of the initial $\mathrm{TN}$ is greater for cultivated land use and older drained wetlands; however, this trend is not evident for TP.
It would be expected that older drained wetlands would have a greater cumulative nutrient loss as measured by the percentage of the initial nutrient mass. However, because the data set is small and unevenly distributed with regard to time since drainage (most of the drained areas used for grazing were drained more recently than those used for cultivation), it is difficult to determine whether land use has any affect on nutrient loss. To aid in this determination, the rate constants calculated for the estimation of annual TN and TP loss based on a first-order rate law (see section "Calculation of Decay Rates and Annual Estimates of Peat and Nutrient Loss") were used for comparison. The rate constants for TN and TP are characteristic of a particular drained wetland under consideration but are independent of both the time since drainage and the quantity of initial nutrient mass at a drained wetland. Many of the conditions that may influence the rate constants are related to land use as discussed in the section "Drainage of Wetlands and Effects of Land Use." The drained areas used for the cultivation of crops generally have larger rate constants for TN (and thereby a greater percentage of TN loss per year) than the areas used for cattle grazing (fig. 12). This relation is not evident for TP (fig. 12). The apparent relation between loss of nitrogen and land use may be the result of tillage of the cultivated lands, which would accelerate decomposition of peat soils, and compaction of the grazed lands by cattle, which would retard decomposition of the peat soils. However, there are other factors that could influence the rates of nutrient loss that have not been fully considered, such as temperature and the length and frequency of inundation by water. These factors may be especially important because the rate constants for individual drained wetlands were not determined for identical time periods owing to differences of when drainage began. Therefore, although land use and larger rate constants for annual TN loss appear correlated, the apparent relation is not necessarily causal.

Given the current data, the estimates of nutrient loss from the decomposition of peat soils contained in the drained wetlands may place an upper limit on the actual nutrient loads contributed to Upper Klamath Lake from this source. Possible outputs for the nutrients lost from the peat soils of the drained wetlands include drainage to the lake, the harvesting of crops or grazing by cattle (Farnham, 1976), wind loss, erosion, and fire. Nitrogen also can be lost as a gas by denitrification and the volatilization of ammonia (Farnham, 1976) or by sorption of ammonia. 

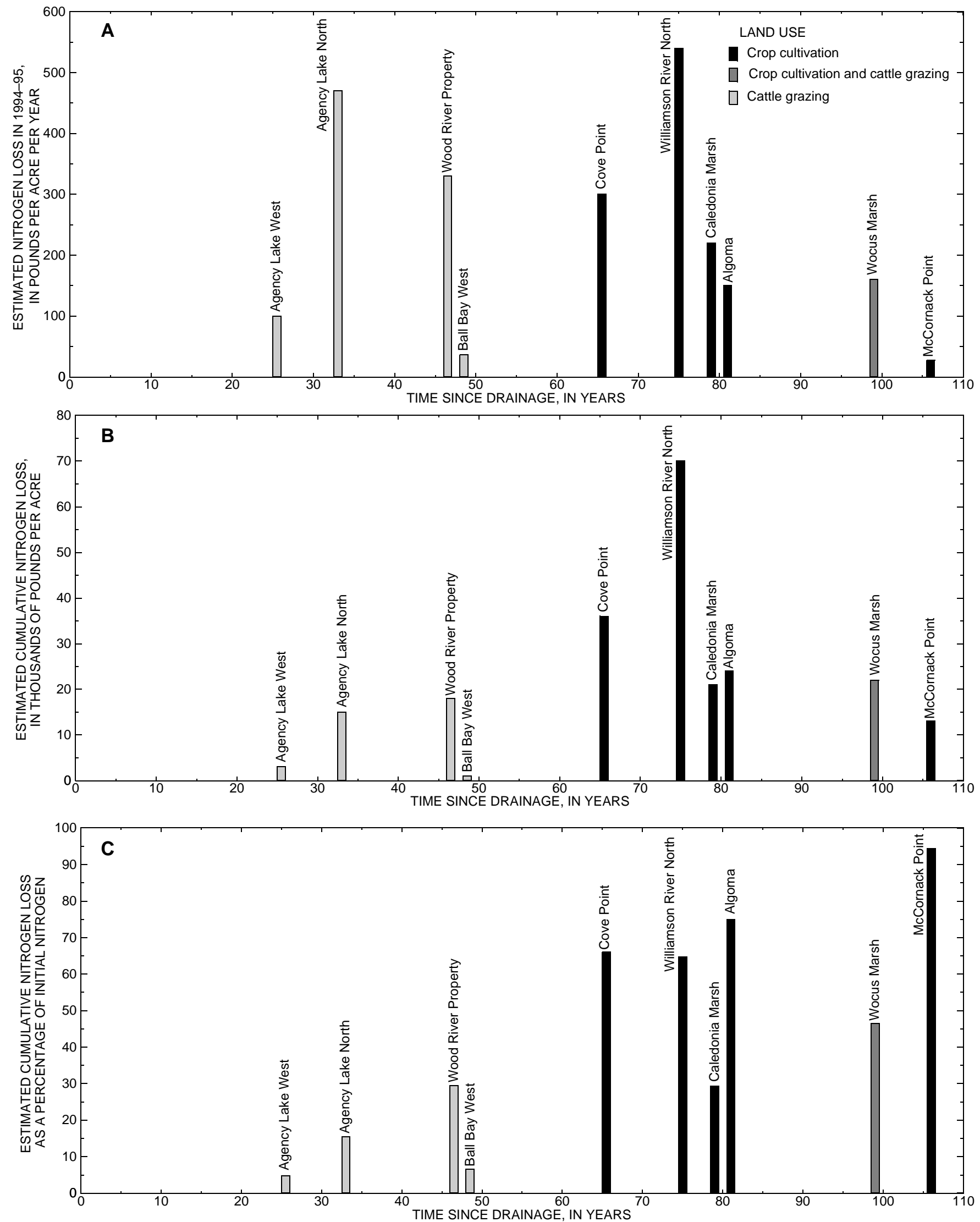

Figure 10. Nitrogen loss in drained wetlands, Upper Klamath Lake, Oregon:

A. Estimated annual nitrogen loss in 1994-95 per unit area at each drained wetland.

B. Estimated cumulative nitrogen loss per unit area at each drained wetland.

C. Estimated cumulative nitrogen loss as a percentage of initial nitrogen at each drained wetland. 

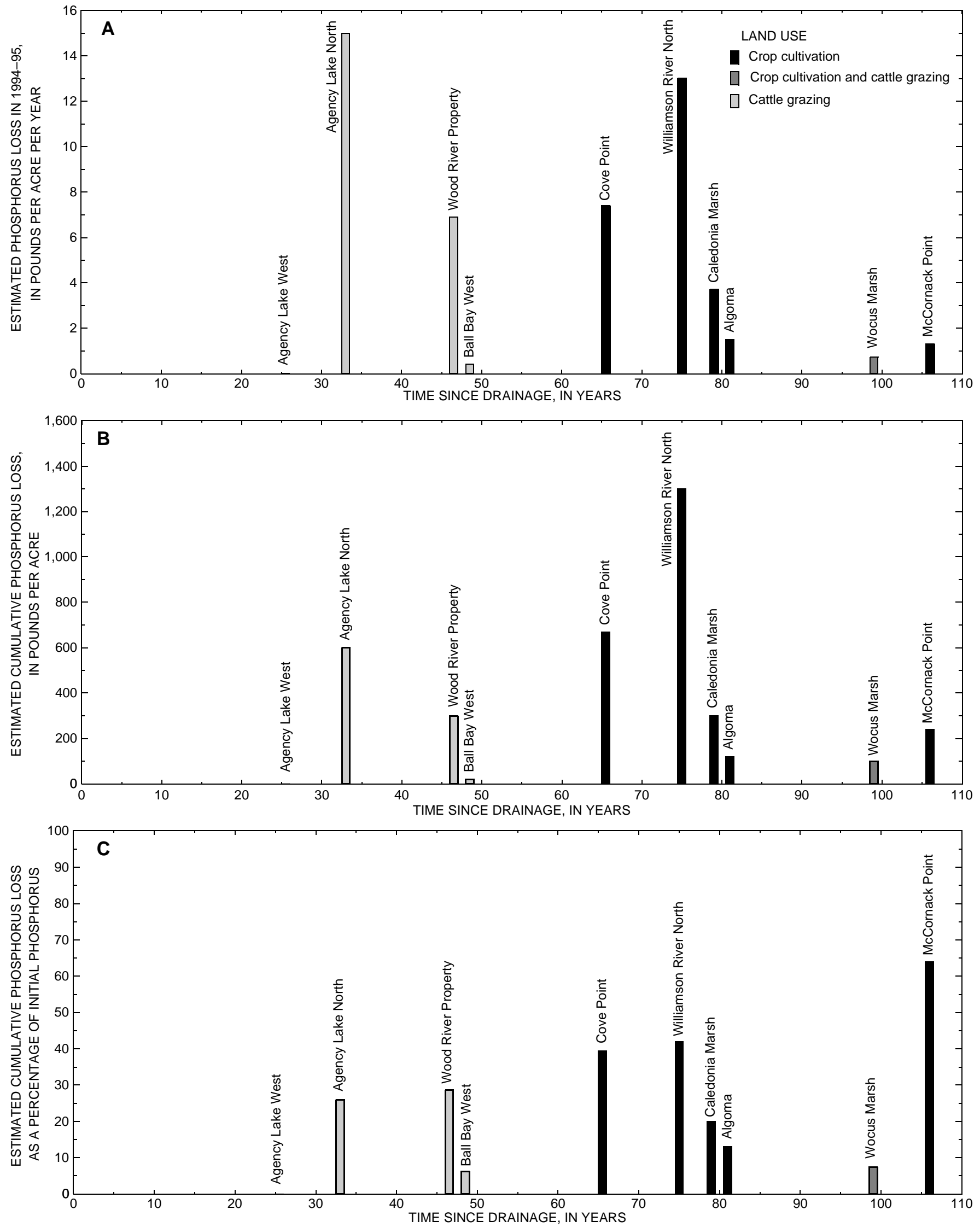

Figure 11. Phosphorus loss in drained wetlands, Upper Klamath Lake, Oregon:

A. Estimated annual phosphorus loss in 1994-95 per unit area at each drained wetland.

B. Estimated cumulative phosphorus loss per unit area at each drained wetland.

C. Estimated cumulative phosphorus loss as a percentage of initial phosphorus at each drained wetland. 
Table 14. Initial, present-day, and cumulative loss of peat and nutrients from drained wetlands by land use, expressed as mass and yield

[Initial is prior to the beginning of drainage of a wetland for agricultural use. Present day is 1995. Cumulative loss is the difference between initial and present day. MASS, in tons; YIELD, in pounds per acre. Values for individual drained wetlands are presented using two significant figures. Sums were calculated using masses for individual areas and are rounded to the nearest $100,000,10,000$, and 100 tons for peat, total nitrogen, and total phosphorus, respectively. See section "Estimation of Nutrient Loss Using Change in Nutrient Mass of Drained Wetland Soils" for method of calculation]

\begin{tabular}{|c|c|c|c|c|c|c|c|c|c|c|c|}
\hline \multicolumn{12}{|c|}{ MASS } \\
\hline \multirow[b]{2}{*}{ Drained wetland } & \multirow[b]{2}{*}{$\begin{array}{c}\text { Area } \\
\text { (acres) }\end{array}$} & \multirow[b]{2}{*}{$\begin{array}{c}\text { Year } \\
\text { drained }\end{array}$} & \multicolumn{3}{|c|}{$\begin{array}{l}\text { Peat } \\
\text { (tons) }\end{array}$} & \multicolumn{3}{|c|}{$\begin{array}{l}\text { Total nitrogen } \\
\text { (tons) }\end{array}$} & \multicolumn{3}{|c|}{$\begin{array}{l}\text { Total phosphorus } \\
\text { (tons) }\end{array}$} \\
\hline & & & Initial & Present day & $\begin{array}{c}\text { Cumulative } \\
\text { loss }\end{array}$ & Initial & Present day & $\begin{array}{l}\text { Cumulative } \\
\text { loss }\end{array}$ & Initial & Present day & $\begin{array}{l}\text { Cumulative } \\
\text { loss }\end{array}$ \\
\hline \multicolumn{12}{|c|}{ Land use-crop cultivation } \\
\hline McCornack Point & 260 & 1889 & 78,000 & 45,000 & 33,000 & 1,800 & 150 & 1,700 & 50 & 18 & 32 \\
\hline Algoma & 1,200 & 1914 & 860,000 & 600,000 & 260,000 & 20,000 & 5,200 & 15,000 & 610 & 530 & 80 \\
\hline Caledonia Marsh & 2,500 & 1916 & $3,800,000$ & $3,400,000$ & 400,000 & 82,000 & 58,000 & 24,000 & 2,000 & 1,600 & 400 \\
\hline Williamson River North & 3,200 & 1920 & $7,900,000$ & $5,900,000$ & $2,000,000$ & 170,000 & 64,000 & 110,000 & 5,000 & 2,900 & 2,100 \\
\hline Cove Point & 550 & $1919-40$ & 630,000 & 460,000 & 170,000 & 15,000 & 5,100 & 9,900 & 430 & 260 & 170 \\
\hline \multicolumn{12}{|c|}{ Land use-crop cultivation and cattle grazing } \\
\hline Wocus Marsh & 3,800 & 1896 & $3,700,000$ & $3,000,000$ & 700,000 & 86,000 & 46,000 & 40,000 & 2,700 & 2,500 & 200 \\
\hline \multicolumn{12}{|c|}{ Land Use-cattle grazing } \\
\hline Ball Bay West & 410 & $1946-47$ & 260,000 & 250,000 & 10,000 & 6,100 & 5,700 & 400 & 160 & 150 & 10 \\
\hline Wood River Property & 2,900 & $1940-57$ & $4,000,000$ & $3,600,000$ & 400,000 & 88,000 & 62,000 & 26,000 & 2,100 & 1,500 & 600 \\
\hline Agency Lake North & 2,600 & 1962 & $6,800,000$ & $6,600,000$ & 200,000 & 130,000 & 110,000 & 20,000 & 2,700 & 2,000 & 700 \\
\hline Agency Lake West & 4,600 & $1968-71$ & $9,500,000$ & $9,500,000$ & 0 & 210,000 & 200,000 & 10,000 & 3,400 & 3,400 & 0 \\
\hline Total & 22,020 & -- & $37,600,000$ & $33,400,000$ & $4,200,000$ & 820,000 & 570,000 & 250,000 & 19,200 & 14,900 & 4,300 \\
\hline \multicolumn{12}{|c|}{ YIELD } \\
\hline & & & \multicolumn{3}{|c|}{$\begin{array}{c}\text { Peat } \\
\text { (pounds/acre) }\end{array}$} & \multicolumn{3}{|c|}{$\begin{array}{l}\text { Total nitrogen } \\
\text { (pounds/acre) }\end{array}$} & \multicolumn{3}{|c|}{$\begin{array}{l}\text { Total phosphorus } \\
\text { (pounds/acre) }\end{array}$} \\
\hline Drained Wetland & $\begin{array}{c}\text { Area } \\
\text { (acres) }\end{array}$ & $\begin{array}{c}\text { Year } \\
\text { drained }\end{array}$ & Initial & Present day & $\begin{array}{c}\text { Cumulative } \\
\text { loss }\end{array}$ & Initial & Present day & $\begin{array}{l}\text { Cumulative } \\
\text { loss }\end{array}$ & Initial & Present day & $\begin{array}{l}\text { Cumulative } \\
\text { loss }\end{array}$ \\
\hline \multicolumn{12}{|c|}{ Land use-crop cultivation } \\
\hline McCornack Point & 260 & 1889 & 590,000 & 340,000 & 250,000 & 14,000 & 1,100 & 13,000 & 370 & 130 & 240 \\
\hline Algoma & 1,200 & 1914 & $1,400,000$ & 980,000 & 420,000 & 33,000 & 8,600 & 24,000 & 1,000 & 880 & 120 \\
\hline Caledonia Marsh & 2,500 & 1916 & $3,000,000$ & $2,700,000$ & 300,000 & 67,000 & 46,000 & 21,000 & 1,600 & 1,300 & 300 \\
\hline Williamson River North & 3,200 & 1920 & $4,900,000$ & $3,700,000$ & $1,200,000$ & 110,000 & 40,000 & 70,000 & 3,100 & 1,800 & 1,300 \\
\hline Cove Point & 550 & $1919-40$ & $2,300,000$ & $1,700,000$ & 600,000 & 54,000 & 18,000 & 36,000 & 1,600 & 930 & 670 \\
\hline \multicolumn{12}{|c|}{ Land use-crop cultivation and cattle grazing } \\
\hline Wocus Marsh & 3,800 & 1896 & $2,000,000$ & $1,600,000$ & 400,000 & 46,000 & 24,000 & 22,000 & 1,400 & 1,300 & 100 \\
\hline \multicolumn{12}{|c|}{ Land use-cattle grazing } \\
\hline Ball Bay West & 410 & $1946-47$ & $1,300,000$ & $1,200,000$ & 100,000 & 29,000 & 28,000 & 1,000 & 760 & 740 & 20 \\
\hline Wood River Property & 2,900 & $1940-57$ & $2,800,000$ & $2,500,000$ & 300,000 & 61,000 & 43,000 & 18,000 & 1,400 & 1,100 & 300 \\
\hline Agency Lake North & 2,600 & 1962 & $5,300,000$ & $5,100,000$ & 200,000 & 100,000 & 85,000 & 15,000 & 2,100 & 1,500 & 600 \\
\hline Agency Lake West & 4,600 & $1968-71$ & $4,200,000$ & $4,100,000$ & 100,000 & 91,000 & 88,000 & 3,000 & 1,500 & 1,500 & 0 \\
\hline
\end{tabular}



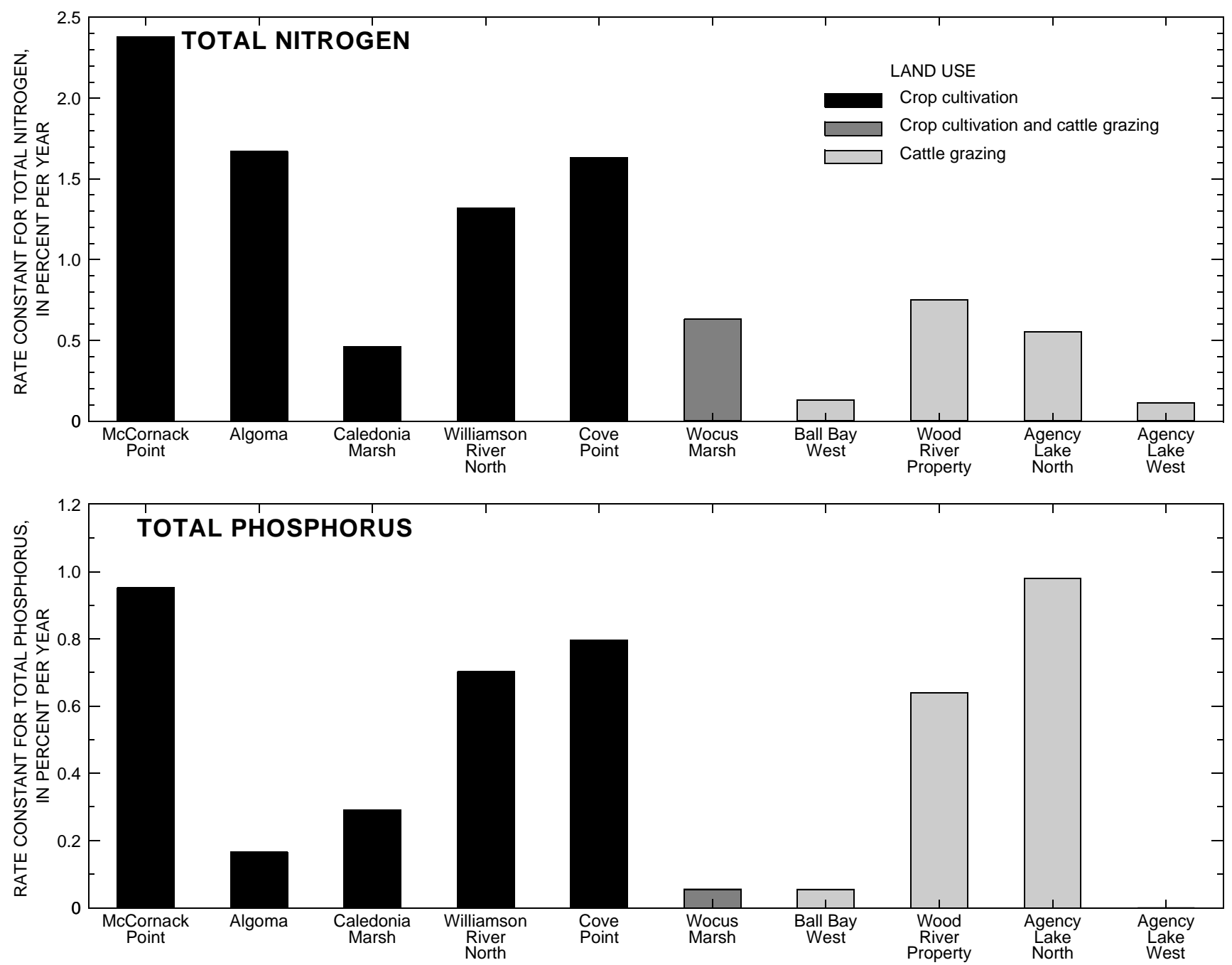

Figure 12. Rate constants for estimation of nutrient loss using a first-order rate law for each drained area by land use. (The rate constant is the fraction of the nutrient mass that is lost on an annual basis and, as present in this figure, is expressed as a percentage and must be divided by 100 before use in the first-order rate law equation.)

Phosphorus can become stored by adsorption or exchanged within adjacent soil layers or the sediments of irrigation ditches.

\section{Comparison of Estimates of Nutrient Loads}

\section{Nutrient Loads from Peat Soils and Discharge Pumps}

A comparison was made of the annual nutrient yields for the drained wetlands calculated by the two approaches used in this study. The estimates determined using the change in nutrient mass of the peat soils are substantially larger than the estimates made by analysis of the pump discharge. The mean of the annual yields of TN for the 1993-95 water years was calculated by nutrient loss from the soils. It ranged from about 16 to 65 times the mean of the annual yields of TN calculated using pump discharge over the same period for individual drained areas.
The mean of the annual yields of TP for the 1993-95 water years calculated by nutrient loss from soils ranged from about 1.6 to 7 times the mean of the annual yields of TP calculated for individual drained areas using pump discharge over the same period.

There are several reasons for these large differences. The nutrient yields calculated using nutrient loss from soils do not account for other possible outputs of nutrients from the soils. These outputs can include volatilization of nitrogen gas and ammonia, uptake by crops or forage, and the adsorption or exchange of phosphorus or ammonia with adjacent soils or sediments. In addition, the soil-loss estimates represent time-averaged contributions to the lake estimated on the basis of the entire time since drainage began, which may be quite different from measurements made in any particular year. In contrast, the pump discharge integrates all inputs and outputs for 
nutrients and are subject to year-specific variations due to temperature, land use, frequency and length of inundation, and other factors. Such estimates are particularly useful for comparisons with same-year loading estimates from other sources.

\section{Nutrient Loads from Peat Soils and Estimates by Miller and Tash}

The preliminary nutrient budget prepared by Miller and Tash (1967, p. 9) for Upper Klamath Lake for a 14-month period during 1965-66 estimated nutrient loads from agricultural drainage to be 241 tons of nitrogen and 133 tons of phosphorus. The values of the annual loss of nitrogen and phosphorus calculated for all the drained areas existing during the period 1965-66 that were sampled in this study $(3,500$ tons and 73 tons, respectively) are about 15 times larger and about 0.55 times smaller, respectively, than the values determined by Miller and Tash. As discussed above in the section "Nutrient Loads from Peat Soils and Discharge Pumps," there are several reasons that might explain the differences between these estimates. In addition, Miller and Tash used the agricultural drainage from five pumping stations representing about 9,300 acres of drained wetlands, whereas the present study considered agricultural nutrient loss from nine drained wetlands that were present during the 1965-66 period, totalling about 17,400 acres. The difference in the size of drained area considered for each study makes an evaluation of the estimates difficult. Unfortunately, Miller and Tash provided only a sum total of agricultural drainage, thereby prohibiting direct comparison between nutrient loads for individual drained areas examined in both studies. It should also be noted that the 14-month period of study used by Miller and Tash complicates comparisons to annual estimates of nutrient loading.

\section{Nutrient Loss from Upper Klamath Lake Peat Soils and Estimates for Other Wetlands}

Comparisons were attempted between the nutrient loss calculated for the peat soils within the drained wetlands adjacent to Upper Klamath Lake and peat soils from other wetlands. Data on nutrient loss from wetlands are scarce, although values have been reported by Pollett (1972), Reddy (1982), Karlovski and Brezgunov (1988), Okruszko and others, (1988), Walbridge (1991), and Otabbong and Linden (1992). However, because of differences in land use, time since drainage, mean annual temperatures, and especially the thickness of soils and their proximity to the surface, these studies were unsuitable for comparison. It is of special interest to note that these studies typically estimated losses based on changes only in the plow layer (about the top 6-12 inches) rather than the entire affected soil profile as was done in the present study.

\section{IMPLICATIONS AND SUGGESTIONS FOR FURTHER STUDY}

The results of this study could be useful in helping to prioritize which drained wetlands might provide the greatest benefits with regard to reducing nutrient loads to the lake if restoration or land-use modifications are instituted. If the water table rises to predrainage levels, the peat soils might become inundated most of the year. This inundation could result in the continued long-term storage of nutrients already present within the peat soils by reducing the aerobic decomposition of these soils that occurs when they are exposed to air or oxygenated water. The results from the present study can be used to identify the drained wetlands having the greatest nutrient yields and stores, information which could be included in a cost-benefit analysis for restoration activities. Such activities have already begun as evidenced by the recent acquisition of drained wetland areas at the Wood River and Williamson River North properties. Planned restoration at these sites could produce significant reduction in the quantity of nutrients released by the decomposition of peat soils of these areas. The maximum benefit, in terms of decreasing potential nutrient loss due to peat decomposition, could be the reduction of TN and TP loss to about one-half that of the 1994-95 annual loss estimated for all the drained wetlands sampled for this study. In addition, nitrogen and phosphorus contained in tributary waters that are routed through the restored wetlands might become sequestered in wetland plant material. This sequestration could result in additional reductions in nutrient loading to Upper Klamath Lake.

One implication of the present study results relates to the intentional lowering of Upper Klamath Lake and the possible subsequent increase in nutrient loading from undrained wetlands. Because of the shallowness of Upper Klamath Lake, lower lake levels can expose as much as 30,000 acres (table 1) of lake bottom to oxygen in the air. Much of the area that becomes uncovered consists of submerged wetlands 
(Hubbard, 1970) and may contain substantial quantities of organic soils. Therefore, lowering the lake level could increase the aerobic decomposition of these soils that occurs when they are exposed to air or oxygenated water. This decomposition could result in the release of nitrogen and phosphorus into the lake from the undrained wetlands.

The results of this study could also have implications related to the possible effects on water quality resulting from rotating between flooded wetlands and agricultural cropland as has been proposed for parts of the nearby Tule and Lower Klamath Lakes National Wildlife Refuges. If the soils in these areas behave in a manner similar to the soils examined in this study, then draining these previously undisturbed wetland areas even temporarily could result in a release of nutrients to the receiving water bodies unless water and crops can be managed to avoid this effect.

Suggestions for further study include:

1. Collect soil, water quality, and discharge data for the areas undergoing wetland restoration. The present study provides baseline data on initial conditions within the drained wetlands; the effectiveness of restoration activities can be monitored by comparing later conditions to the baseline data.

2. Continue to sample drained wetlands areas where past land use has remained unchanged. This could be useful for comparison with restored wetlands by removing effects such as weather patterns. Additional sampling of previously unsampled drained wetlands could help to refine the relationship between land use and nutrient loss.

3. Evaluate nutrient loading from ground water to Upper Klamath Lake.

4. Estimate the possible nutrient loading from undrained wetlands as a result of lowering lake levels at Upper Klamath Lake.

5. Collect baseline data on present-day nutrient mass within the organic soils of the flooded wetlands and agricultural cropland proposed for rotation at Tule and Lower Klamath Lakes National Wildlife Refuges.

6. Collect additional data on nutrient inputs and outputs such as irrigation, ground-water seepage, fertilizer application, cattle, waterfowl, and crops, to develop a detailed nutrient budget for the wetlands.

\section{SUMMARY}

Upper Klamath Lake and the connecting Agency Lake constitute a large, shallow lake in south-central Oregon that the historical record indicates has likely been eutrophic since its discovery by non-Native Americans. In recent decades, however, the lake has had annual occurrences of near-monoculture blooms of the blue-green alga Aphanizomenon flos-aquae that are thought to be a result of accelerated eutrophication. In 1988, two sucker species endemic to the lake, the Lost River sucker (Deltistes luxatus) and the shortnose sucker (Chasmistes brevirostris), were listed as endangered by the U.S. Fish and Wildlife Service, and it has been proposed that their decline is due to the poor water quality associated with extremely long and productive algal blooms. It has also been proposed that the effluent drained from wetlands has contributed to worsening water quality (Bortleson and Fretwell, 1993).

Since the turn of century, most of the wetlands adjacent to Upper Klamath Lake have been drained for agriculture-cultivation of crops and grazing of cattle. Wetland areas were reclaimed from the lake by building dikes to isolate them from the lake, constructing a series of drainage ditches, and installing pumps to drain the water and maintain a lowered water table. A consequence of lowering the water table is the increased ability of air and oxygenated water to move through the subsurface and facilitate the rapid aerobic decomposition of the peat soils. Nutrients, nitrogen and phosphorus, are then liberated, leach into adjacent ditches, and are subsequently pumped to the lake or its tributaries. The rate of peat decomposition may be related to the time since drainage and the type of agricultural land use. On lands cultivated for crops, farming practices, such as disking and furrowing, could enhance the movement of air and oxygenated water, resulting in rapid rate of decomposition. In contrast, on grazed lands, the compaction of soils by cattle probably inhibits the movement of air and oxygenated water and results in a slower rate of decomposition relative to drained wetlands used for the cultivation of crops.

This report presents the results of a cooperative study between the U.S. Geological Survey and the Bureau of Reclamation to estimate the nutrient loading to Upper Klamath Lake from adjacent drained wetlands. Nutrient loading from drained wetlands was estimated using two independent techniques. The first 
method involved the measurement of the quantity and quality of water discharged by pumps draining the wetlands. The second method estimated the initial (prior to drainage) and present-day nutrient mass of the organic soils within the drained wetlands and calculated the change (or loss) in nutrient mass.

In an effort to estimate the nutrient loading from the water pumped off selected drained wetlands adjacent to Upper Klamath Lake, nutrient concentrations were measured during 1993-95, and the electrical meters associated with the pumping stations were monitored to determine the annual volume of water pumped based on the power consumption. Annual loads and yields of total nitrogen and total phosphorus were estimated from concentration data and the volume of water pumped during the water year. Because of the possible error associated with the method used to estimate the annual volume of water pumped, these loading estimates are only an indication of the order of magnitude of nutrient contributions from these areas.

The annual nutrient loads and yields calculated for the water discharged from six pumping stations represent an integration of many factors, including land use, the time since drainage of the wetlands, and multiple sources of inputs and outputs. Although there was apparent variation in the nutrient concentrations measured, there was little variation in the annual total nitrogen loads or yields (medians of about 18 tons/yr [tons per year] and about $8 \mathrm{lbs} / \mathrm{acre} / \mathrm{yr}$ [pounds per acre per year], respectively) among sites for a given year or among years for a given site. There was, however, much more variation among sites in the total phosphorus loads and yields (medians of about 3 tons/yr and about $2 \mathrm{lbs} / \mathrm{acre} / \mathrm{yr}$, respectively). The sum of the annual loads of nitrogen and phosphorus calculated for each of the pumping stations in 1995 was 80 tons/yr and 15 tons/yr, respectively.

In 1995, soil-coring was done to ascertain the nature and extent of the organic soils in the drained and undrained wetlands. This effort included description of the soil stratigraphy and collection of soil samples for physical and chemical analysis. Eleven drained and 5 undrained wetland areas were selected for coring and sampling. The 11 drained wetland areas represent about 74 percent of the approximately 31,000 acres of drained wetlands adjacent to Upper Klamath Lake. The five undrained wetlands represent nearly all of the 17,400 acres of undrained wetlands around the lake. Sixty-one soil cores with an average length of about $9 \mathrm{ft}$ were described and photographi- cally documented. A total of 229 soil samples were collected, of which 181 were analyzed for physical and chemical characteristics, including nutrient content.

The present-day soil nutrient mass was calculated for each drained wetland using the nutrient content and the present-day peat mass as determined from the bulk density, thickness of the organic soil layers, and area of the wetland. The initial nutrient mass prior to drainage was calculated for each drained wetland by estimating the initial nutrient content and peat mass. The initial nutrient content was estimated by using data from the undrained wetlands. The initial peat mass was estimated using the bulk density from the undrained wetlands and an estimate of the amount of decomposition that had occurred since drainage, derived by comparing present-day ash content with that of the undrained wetlands. The cumulative loss of nutrient mass since drainage was calculated as the change between initial and present-day nutrient mass for each drained area.

The cumulative yield of total nitrogen and total phosphorus loss from the organic soils of individual wetlands since drainage ranged from 3,000 to 70,000 $\mathrm{lbs} / \mathrm{acre}$ and from 0 to $1,300 \mathrm{lbs} / \mathrm{acre}$, respectively. For all the drained wetlands sampled, the cumulative loss of nitrogen and phosphorus since drainage totaled 250,000 tons and 4,300 tons, respectively. This loss represents about 30 percent and 22 percent of the mass of nitrogen and phosphorus, respectively, that initially existed in the organic soils. The loss of nutrients from the drained wetlands is considered to be a maximum estimate of the possible contribution of nutrients to Upper Klamath Lake from the peat soils of the drained wetlands sampled. However, not all the nutrients released by the soils are discharged to the lake. Nutrients lost from the peat soils of the drained wetlands may have been taken up by crops and harvested or consumed by grazing cattle. In addition, nitrogen can be lost to the atmosphere by denitrification and the volatilization of ammonia; phosphorus may be bound to adjacent soil layers by adsorption.

The annual nutrient loss for the period 1994-95 was calculated using a first-order rate law to describe nutrient loss since drainage began. For individual drained wetlands, the yield of nitrogen and phosphorus lost from the organic soils for the period 1994-95 ranged from 27 to $540 \mathrm{lbs} / \mathrm{acre} / \mathrm{yr}$ and from 0 to $15 \mathrm{lbs} / \mathrm{acre} / \mathrm{yr}$, respectively. The total mass of nitrogen and phosphorus loss during this period was 3,000 tons/yr and 60 tons/yr, respectively, for 
all drained wetlands that were sampled. The yield and mass of nutrient loss determined in this fashion reflect what might be expected on the basis of time-averaged or long-term contributions of nutrients to the lake and do not reflect the specific conditions existing during the period 1994-95.

Implications resulting from this study include (1) low stages of Upper Klamath Lake could result in increased decomposition of peat soils of exposed wetlands within the lake's perimeter, resulting in the release of nitrogen and phosphorus, and (2) the rotation between flooded wetlands and agricultural cropland as proposed for parts of the nearby Tule and Lower Klamath Lakes National Wildlife Refuges could result in a release of nutrients to the receiving water bodies.

The results of this study could be useful in helping to prioritize which drained wetlands could provide the greatest benefits with regard to reducing nutrient loads to the lake if restoration or land-use modifications are instituted. Recent acquisition and planned restoration of drained wetland areas at the Wood River and Williamson River North properties could produce significant reduction in the quantity of nutrients released by the decomposition of peat soils of these areas. If the water table rises to predrainage levels, the peats soils could become inundated most of the year, resulting in the continued long-term storage of nutrients within the peat soils by reducing aerobic decomposition. The maximum benefit, in terms of decreasing potential nutrient loss due to peat decomposition, could be the reduction of total nitrogen and total phosphorus loss to about one-half that of the 1994-95 annual loss estimated for all the drained wetlands sampled for this study.

\section{SELECTED REFERENCES}

Adam, D.P., Bradbury, J.P., Carter, Claire, Dean, W.E., Hakala, Kathryn, McGann, Mary, Reynolds, R.L., Rieck, H.J., Roberts, Andrew, Rosenbaum, J.G., Sarna-Wojcicki, A.M., Schiller, Karen, and Whitlock, Cathy, 1995, Status report on cores taken in 1991-1992 in the Upper Klamath Basin and vicinity, Oregon and California, in Adam, D.P., Bradbury, J.P., Dean, W.E., Gardner, J.V., and Sarna-Wojcicki, A.M., eds., Report of 1994 workshop on the correlation of marine and terrestrial records of climate changes in the western United States: U.S. Geological Survey Open-File Report 95-34, p. 13-29.
Adam, D.P., Rieck, H.J., McGann, Mary, Schiller, Karen, Sarna-Wojcicki, A.M., and Trimble, D.A., 1994, Lithologic description of sediment cores from Wocus Marsh, Klamath County, Oregon: U.S. Geological Survey Open-File Report 94-189, 65 p.

Akins, Glenn J., 1970, The effects of land use and land management on the wetlands of the Upper Klamath Basin: Bellingham, Washington, Western Washington State College, M.S. thesis, 122 p.

American Public Health Association, American Public Water Works Association, and Water Pollution Control Federation, 1989, Standard methods for the examination of water and wastewater (17th ed.): Washington, D.C., American Public Health Association, $1527 \mathrm{p}$.

Bacon, C.R., and Lanphere, M.A., 1990, The geologic setting of Crater Lake, Oregon, in Drake, E.T., Larson, G.L., Dymond, Jack, and Collier, Robert, eds., Crater Lake-An ecosystem study: Sixty-Ninth Annual Meeting of the Pacific Division/American Association for the Advancement of Science, Oregon State University, Corvallis, Oregon, June 18-22, 1988, p. 19-27.

Bartels, Rüdiger, and Scheffer, Bernard, 1996, Nitrate enrichment in fenland soils on meadows after ploughing: Proceedings of the 10th International Peat Congress, Volume 4, Bremen, Germany, May 27-June 2, 1996, p. 43-48.

Bartholomay, R.C., and Williams, L.M., 1996, Evaluation of preservation methods for selected nutrients in ground water, Idaho National Engineering Laboratory, Idaho: U.S. Geological Survey WaterResources Investigations Report 96-4260, 16 p.

Belanger, T.V., and Van Vonderen, S.D., 1984, Water quality characteristics of agricultural pumpage in the Upper St. Johns River, Florida: Water Resources Bulletin, v. 20, no. 3, p. 349-358.

Berglund, K., 1992, Subsidence of cultivated peat soilsTwo case studies in Sweden: Proceedings of the 9th International Peat Congress, Volume 3, Uppsala, Sweden, June 22-26, 1992, p. 251.

Boelter, D.H., 1969, Physical properties of peats as related to their degree of decomposition: Soil Science Society of America Proceedings, v. 33, no. 4, p. 606-609.

Bortleson, G.C., and Fretwell, M.O., 1993, A review of possible causes of nutrient enrichment and decline of endangered sucker populations in Upper Klamath Lake, Oregon: U.S. Geological Survey WaterResources Investigations Report 93-4087, 24 p.

Broadbent, F.E., 1960, Factors influencing the decomposition of organic soils of the California Delta: Hilgardia, v. 29, no. 13, p. 587-612. 
Brown, J.L., and Farnham, R.S., 1976, The mineral content of peat and the degree of decomposition: Proceedings of the 5th International Peat Congress, Volume II, Poznan, Poland, August 21-25, 1976, p. 246-253.

Brown, J.L., Malterer, Thomas, and Farnham, R.S., 1984, Surface and subsurface sampling of organic soils: Proceedings of the 7th International Peat Congress, Volume 1, Dublin, Ireland, June 18-23, 1984, p. 54-67.

Brownell, D.L., and Rinallo, M.R., 1995, A selected bibliography of water related research in the Upper Klamath Basin, Oregon: U.S. Geological Survey Open-File Report 95-285, 23 p.

Bureau of Land Management, 1994, Draft resource management plan-Environmental impact statement for the Upper Klamath Basin: Klamath Falls, Oregon, [unknown pagination].

-1995, Proposed resource management plan-Final Environmental impact statement for the Upper Klamath Basin: Klamath Falls, Oregon, [unknown pagination].

Cahoon, J.S., 1985, Soil survey of Klamath County, Oregon, southern part: U.S. Department of Agriculture Soil Conservation Service in cooperation with Oregon Agriculture Experiment Station, 269 p., 106 soil map sheets.

Cameron, C.C., 1970, Peat resources of the unglaciated uplands along the Allegheny structural front in West Virginia, Maryland, and Pennsylvania:

U.S. Geological Survey Professional Paper 700-D, p. 153-161.

1973, Peat in Brobst, D.A., and Pratt, W.P., eds, 1973, United States mineral resources:

U.S. Geological Survey Professional Paper 820, p. 505-513.

1975, Some peat deposits in Washington and southeastern Aroostook Counties, Maine:

U.S. Geological Bulletin 1317-6., 40 p. 1989, Peat and its occurrence as a resource in Maine: Studies in Maine Geology, v. 5, p. 125-146.

Cameron, C.C., and Anderson, W.A., 1980, Peat resources of the Great Heath, Washington County, Maine: U.S. Geological Survey Open-File Report 80-39, $10 \mathrm{p}$.

Cameron, C.C., Esterle, J.S., Palmer, C.A., 1989, The geology, botany and chemistry of selected peatforming environments from temperate and tropical latitudes: International Journal of Coal Geology, v. 12 , p. $105-156$.

Campbell, S.G., ed., 1993a, Environmental research in the Klamath Basin, Oregon-1991 annual report: Denver, Colorado, Bureau of Reclamation, Research and Laboratory Services Division, Report No. R-93-13, 212 p. 1993b, Environmental research in the Klamath Basin, Oregon-1992 annual report: Denver, Colorado, Bureau of Reclamation, Research and Laboratory Services Division, Report No. R-93-16, $341 \mathrm{p}$.

Campbell, S.G., and Ehinger, W.J., 1993, Wood River hydrology and water quality study, in Campbell, S.G., ed., Environmental research in the Klamath Basin, Oregon-1991 annual report: Denver, Colorado, Bureau of Reclamation Report No. R-93-13, p. 7-79.

Campbell, S.G., and Ehinger, W.J., and Kann, Jacob, 1993, Wood River hydrology and water quality study, in Campbell, S.G., ed., Environmental research in the Klamath Basin, Oregon-1992 annual report: Denver, Colorado, Bureau of Reclamation Report No. R-93-16, p. 9-90.

Canning, S.P., Fazio, P.C., Fisher, Donna, Gutman, E.L., Hsia, C.T., Kauffman, S.L., Kramer, Joanne, Lane, Marianne, Leinweber, C.M., and McGee, P.A., eds., 1991, 1991 Annual book of ASTM standards-

Section 4 construction-Volume 04.08 soil and rock; Dimension Stone; Geosynthetics: Philadelphia, Pennsylvania, American Society for Testing and Materials, $1182 \mathrm{p}$.

Carlson, J.R., 1993, The evaluation of wetland changes around Upper Klamath Lake, Oregon, using multitemporal remote sensing techniques, in Campbell, S.G., ed., Environmental research in the Klamath Basin, Oregon-1991 annual report: Denver, Colorado, Bureau of Reclamation Report No. R-93-13, p. 197-202.

CH2M Hill, 1996, Feasibility review-Williamson River restoration-The Nature Conservancy: Corvallis, Oregon, CH2M Hill, March, 13 p.

Chason, D.B., and Siegel, D.I., 1986, Hydraulic conductivity and related physical properties of peat, Lost River Peatland, Northern Minnesota: Soil Science, v. 142, no. 2, p. 91-99.

Chow, V.T., ed., 1964, Handbook of applied hydrology: New York, McGraw-Hill, 1418 p.

Cowardin, L.M., Carter, Virginia, Golet, F.C., and Laroe, E.T., 1979, Classification of wetlands and deepwater habitats of the United States: U.S. Fish and Wildlife Service, FWS/OBS-79/31, 103 p.

Crowley, S.S., Dufek, D.A., Stanton, R.W., and Ryer, T.A., 1994, The effects of volcanic ash disturbances on a peat-forming environment-Environmental disruption and taphonomic consequences: PALAIOS, v. 9, p. 158-174.

Dicken, S.N., 1980, Pluvial Lake Modoc, Klamath County, Oregon, and Modoc and Siskiyou Counties, California: Oregon Geology, v. 42, no. 11, p. 179-187. 
Dicken, S.N., and Dicken, E.F., 1985, The legacy of ancient Lake Modoc-A historical geography of the Klamath Lakes Basin: Eugene, University of Oregon, 166 p.

Dileanis, P.D., Schwarzbach, S.E., and Bennett, Jewel, 1996, Detailed study of water quality, bottom sediment, and biota associated with irrigation drainage in the Klamath Basin, California and Oregon, 1990-92: U.S. Geological Survey WaterResources Investigations Report 95-4232, 68 p.

Efimov, V.N., and Lunina, N.F., 1988, Evolution of bog soils in the European part of the USSR due to their agricultural use: Proceedings of the 8th International Peat Congress, Volume 3, Leningrad, USSR, August 14-21, 1988, p. 71-78.

Eggelsmann, R., 1976, Peat consumption under influence of climate, soil condition and utilization: Proceedings of the 5th International Peat Congress, Volume I, Poznan, Poland, August 21-25, 1976, p. 233-247.

Farnham, R.S., 1976, Influence of intensive agriculture on water quality in peatlands: Proceedings of the 5th International Peat Congress, Volume I, Poznan, Poland, August 21-25, 1976, p. 107-117.

Federal Register, 1988, Endangered and threatened wildlife and plants-Determination of endangered status for the shortnose sucker and Lost River sucker: Department of Interior, Fish and Wildlife Service, July 18, 1988, v. 53, no. 137, p. 27130-27134.

Finney, H.R., Gross, E.R., and Farnham, R.S., 1974, Limnic materials in peatlands of Minnesota, in Aandahl, A.R., Buol, S.W., Hill, D.E., and Bailey, H.H., eds., Histosols-Their characteristics, classification, and use: Madison, Wisconsin, Soil Science Society of America, Special Publication Series no. 6, p. 21-31.

Fishman, M.J., ed., 1993, Methods of analysis by the U.S. Geological Survey National Water Quality Laboratory-Determination of inorganic and organic constituents in water and fluvial sediments: U.S. Geological Survey Open-File Report 93-125, $217 \mathrm{p}$.

Fretwell, J.D., Williams, J.S., and Redman, P.J., comps., 1996, National water summary on wetland resources: U.S. Geological Survey Water-Supply Paper 2425, $431 \mathrm{p}$.

Gallagher, J.L., 1978, Decomposition processes-Summary and recommendations, in Good, R.E., Whigham, D.F., and Simpson, R.L., eds., 1978, Freshwater wetlands-Ecological processes and management potential: New York, Academic Press, p. 145-151.

Gearheart, R.A., Anderson, J.K., Forbes, M.G., Osburn, Mark, and Oros, Daniel, 1995a, Watershed strategies for improving water quality in Upper Klamath Lake, Oregon-Volume I: Arcata, California, Humboldt State University, $42 \mathrm{p}$.

-1995b, Watershed strategies for improving water quality in Upper Klamath Lake, Oregon-Volume II:
Arcata, California, Humboldt State University, 270 p., plus references and appendixes.

1995c, Watershed strategies for improving water quality in Upper Klamath Lake, Oregon-Volume III: Arcata, California, Humboldt State University, [unknown pagination].

Geitgey, R.P., 1992, Pumice in Oregon: Oregon Department of Geology and Mineral Industries Special Paper 25, $26 \mathrm{p}$.

Goode, D.A., Marsan, A.A., and Michaud, J.-R., 1977, Water resources in Radforth, N.W., and Brawner, C.O., eds., Muskeg and the northern environment of Canada: University of Toronto Press, p. 299-331.

Gore, A.J.P., 1983, Introduction, in Gore, A.J.P., ed., Ecosystems of the world 4A, Mires-swamp, bog, fen, and moor-General studies: New York, Elsevier, p. 1-34.

Hubbard, L.L., 1970, Water budget of Upper Klamath Lake, southwestern Oregon: U.S. Geological Survey Hydrologic Investigations Atlas HA-351, scale $1: 250,000$.

Hurr, R.T., and Litke, D.W., 1989, Estimating pumping time and ground-water withdrawals using energyconsumption data: U.S. Geological Survey WaterResources Investigation 89-4107, 27 p.

Illian, J.R., 1970, Interim report on the ground water in the Klamath Basin, Oregon: Salem, Oregon State Engineer, 110 p.

Johnson, D.M., Peterson, R.R., Lycan, D.R., Sweet, J.W., and Neuhaus, M.E., 1985, Atlas of Oregon lakes: Corvallis, Oregon State University Press, 317 p.

Kaffka, S.R., Lu, T.X., and Carlson, H.L., 1995, An assessment of the effects of agriculture on water quality in the Tulelake region of California: Tulelake, California, University of California, Intermountain Research and Extension Center, Research Progress Report 108, 85 p.

Kann, Jacob, 1993a, Agency Lake limnology, 1990-91, in Campbell, S.G., ed., Environmental research in the Klamath Basin, Oregon-1991 annual report: Bureau of Reclamation Technical Report R-93-13., p. 103-187.

1993b, Agency Lake limnology, 1992, in Campbell, S.G., ed., Environmental research in the Klamath Basin, Oregon-1992 annual report: Bureau of Reclamation Technical Report R-93-16, p. 91-137.

Karlovski, V.F., and Brezgunov, V.S., 1988, Peat soil liquid body transformation: Proceedings of the 8th International Peat Congress, Volume 4, Leningrad, USSR, August 14-21, 1988, p. 11-18.

Kaunisto, Seppo, 1976, Aspects of nitrogen mobilization in peat: Proceedings of the 5th International Peat Congress, Volume II, Poznan, Poland, August 21-25, 1976, p. 295-305. 
Klamath Consulting Service, Inc., 1983, The Upper Klamath Lake, EPA-314 Clean Lakes Program 1981 to 1983-Phase 1, diagnostic and feasibility study: Klamath Falls, Oregon, 145 p.

Kuntze, H., 1984, The risks of water pollution by agricultural utilization of peatlands and practical defenses: Proceedings of the 7th International Peat Congress, Volume 1, Dublin, Ireland, June 18-23, 1984, p. 246-267.

1992, Peat losses by liming and fertilizing of peatland used as grassland: Proceedings of the 9th International Peat Congress, Volume 2, Uppsala, Sweden, June 22-26, 1992, p. 306-314.

Laenen, Antonius, and LeTourneau, A.P., 1996, Upper Klamath Basin nutrient-loading study-Estimate of wind-induced resuspension of bed sediment during periods of low lake elevation: U.S. Geological Survey Open-File Report 95-414, 11 p.

Laine, J., Vasander, H., and Puhalainen, A., 1992, Effect of forest drainage on the carbon balance of mire ecosystems: Proceedings of the 9th International Peat Congress, Volume 1, Uppsala, Sweden, June 22-26, 1992, p. 170-181.

Lee, Gerhard B., and Manoch, Bamrung, 1974, Macromorphology and micromorphology of a Wisconsin saprist, in Aandahl, A.R., Buol, S.W., Hill, D.E., and Bailey, H.H., eds., Histosols-Their characteristics, classification, and use: Madison, Wisconsin, Soil Science Society of America, Special Publication Series no. 6, p. 47-62.

Leonard, A.R., and Harris, A.B., 1974, Ground water in selected areas in the Klamath Basin, Oregon: Oregon State Engineer Ground Water Report No. 21, 104 p.

Levanon, D., Levin, I., Kipnis, T., and Cohen, U., 1987, The effect of high yielding perennial herbage crops on biological degradation and nitrate accumulations in peat soil: Experimental Agriculture, v. 23, p. 69-74.

Lévesque, M.P., and Mathur, S.P., 1979, A comparison of various means of measuring the degree of decomposition of virgin peat materials in the context of their relative biodegradability: Canadian Journal of Soil Science, v. 59, p. 397-400.

Linsley, R.K., Jr., Kohler, M.A., and Paulhus, J.L.H., 1982, Hydrology for engineers (3d ed.):New York, McGraw-Hill, 508 p.

Lucas, R.E., 1982, Organic soils (histosols)—Formation, distribution, physical and chemical properties and management for crop production: East Lansing, Michigan State University Agricultural Experiment Station, Research Report v. 435 Farm Science, 77 p.

Lynn, W.C., McKinzie, W.E., and Grossman, R.B., 1974, Field laboratory tests for characterization of histosols, in Aandahl, A.R., Buol, S.W., Hill, D.E., and Bailey, H.H., eds., Histosols-Their characteristics, classification, and use: Madison, Wisconsin, Soil
Science Society of America, Special Publication Series no. 6, p. 11-20.

McDonnell, J.G., and Farrell, E.P., 1984, An evaluation of techniques for the measurement of decomposition in peat: Proceedings of the 7 th International Peat Congress, Volume 4, Dublin, Ireland, June 18-23, 1984, p. 358-382.

Maciak, Franciszek, 1972, Effect of fertilization and tillage on content of organic forms of nitrogen in peat soil and its humus fractions: Proceedings of the 4th International Peat Congress, Volume IV, Otaniemi, Finland, June 25-30, 1972, p. 105-120.

Mathur, S.P., and Farnham, R.S., 1985, Geochemistry of humic substances in natural and cultivated peatlands, in Aiken, G.R., McKnight, D.M., Wershaw, R.L., and MacCarthy, Patrick, eds., Humic substances in soil, sediment, and water: New York, Wiley-Interscience, p. 53-85.

Miller, W.E., and Tash, J.C., 1967, Interim report, Upper Klamath Lake studies, Oregon: Corvallis, Oregon, Federal Water Pollution Control Administration, Pacific Northwest Laboratory, Water Pollution Control Research Series, Paper WP-20-8, 37 p.

Montedoro-Whitney Corporation, 1984, Instruction manual for PVM-2A portable velocity meter: San Luis Obispo, California, 21 p. [Available from Montedoro-Whitney Corporation, 2741E McMillan Road, San Luis Obispo, California 93401.]

Mulqueen, J., 1986, Hydrology and drainage of peatland: Environmental Geology and Water Sciences, v. 9, no. 1, p. 15-22.

National Oceanic and Atmospheric Administration, 1994, Climatological Data, Oregon: Asheville, North Carolina, National Climatic Data Center. 1995, Climatological Data, Oregon: Asheville, North Carolina, National Climatic Data Center. 1996, Climatological Data, Oregon: Asheville, North Carolina, National Climatic Data Center.

Nesterenko, I.M., 1976, Subsidence and wearing out of peat soils as a result of reclamation and agricultural utilization of marshlands: Proceedings of the 5th International Peat Congress, Volume I, Poznan, Poland, August 21-25, 1976, p. 218-232.

Newcomb, R.C., and Hart, D.H., 1958, Preliminary report on the ground water resources of the Klamath River Basin, Oregon: U.S. Geological Survey Open-File Report [unnumbered], $248 \mathrm{p}$.

Okruszko, H., Sapek, B., and Szuniewicz, J., 1988, Balance of mineral components in peat soil utilized for a grassland over 24 years: Proceedings of the 8th International Peat Congress, Volume 3, Leningrad, USSR, August 14-21, 1988, p. 226-233.

Oregon Water Resources Department, 1978, Land useKlamath drainage basin, Oregon: Salem, Oregon, scale 1:260,000, 1 sheet. 
Otabbong, E., and Linden, B., 1992, Nitrogen dynamics and control in organic soils-A review: Proceedings of the 9th International Peat Congress, Volume 3, Uppsala, Sweden, June 22-26, 1992, p. 250.

Page, A.L., Miller, R.H., and Keeney, D.R., eds., 1982, Methods of soil analysis-Part 2-Chemical and microbiological properties, (2d ed.): Madison, WI, American Society of Agronomy, Inc. and Soil Science Society of America, Inc., 1159 p.

Patton, C.J., and Truitt, E.P., 1992, Methods of analysis by the U.S. Geological Survey National Water Quality Laboratory-Determination of total phosphorus by a kjeldahl digestion method and an automated colorimetric finish that includes dialysis: U.S. Geological Survey Open-File Report 92-146, $39 \mathrm{p}$.

Peterson, N.V., and McIntyre, J.R., 1970, The reconnaissance geology and mineral resources of eastern Klamath County and western Lake County, Oregon: Oregon Department of Geology and Mineral Industries Bulletin 66, 70 p.

Petukhova, N.N., 1988, On the reclamation-provoked geochemical transformation of peatland in the Byelorussian SSR: Proceedings of the 8th International Peat Congress, Volume 4, Leningrad, USSR, August 14-21, 1988, p. 3-10.

Phinney, H.K., and Peek, C.A., 1961, Klamath Lake-An instance of natural enrichment, in Transcript of 1960 seminar on Algae and metropolitan wastes: Cincinnati, Ohio, R.A. Taft Sanitary Engineering Center, p. 22-27.

Pollett, F.C., 1972, Nutrient contents of peat soils in Newfoundland: Proceedings of the 4th International Peat Congress, Volume III, Otaniemi, Finland, June 25-30, 1972, p. 461-468.

Reddy, K.R., 1982, Mineralization of nitrogen in organic soils: Soil Science Society of America Journal, v. 46, no. 3, p. 561-566.

Rosenbaum, J.G., Reynolds, R.L., Adam, D.P., SarnaWojcicki, A.M., Whitney, C.G., Kerwin, M.W., and Fitzmaurice, P., 1995, Climate records from Quaternary sediment, Buck Lake and Caledonia Marsh, southern Oregon-Comparison of magnetic and pollen data, in Adam, D.P., Bradbury, J.P., Dean, W.E., Gardner, J.V., and Sarna-Wojcicki, A.M., eds., Report of 1994 Workshop on the correlation of marine and terrestrial records of climate changes in the western United States: U.S. Geological Survey Open-File Report 95-34, p. 30-35.

Sartoris, J.J., and Sisneros, D., 1993, Upper Klamath Lake wetlands study, in Campbell, S.G., ed., Environmental research in the Klamath Basin, Oregon-1991 annual report: Bureau of Reclamation Technical Report R-93-13., p. 189-196.
Sartoris, J.J., Sisneros, D., and Campbell, S.G., 1993, Upper Klamath Lake wetlands study, in Campbell, S.G., ed., Environmental research in the Klamath Basin, Oregon-1992 annual report: Bureau of Reclamation Technical Report R-93-16., p. 189-222.

Schalitz, Gisbert, Scholz, Anton, Fischer, Andreas, and Kaiser, Thomas, 1996, Function of large-area extensive pasture on shallow undulated low-moor: Proceedings of the 10th International Peat Congress, Volume 2, Bremen, Germany, May 27-June 2, 1996, p. 184-197.

Segeberg, H., 1962, Vorausberechnung der auf Moorkulturen durch den Schwund von Torfsubstanz zu erwartenden Höhenverluste: Z.f. Kulturtechnik, v. 3, p. 336-367.

Sherrod, D.R., 1993, Historic and prehistoric earthquakes near Klamath Falls, Oregon: Earthquakes and Volcanoes, v. 24, no. 3, p. 106-120.

Sherrod, D.R., and Pickthorn, L.G., 1992, Geologic map of the west half of the Klamath Falls $1^{\circ}$ by $2^{\circ}$ Quadrangle, south-central Oregon: U.S. Geological Survey Miscellaneous Investigations Series, Map I2182, scale 1:250,000.

Smith, James G., 1988, Geologic map of the Pelican Butte Quadrangle, Klamath County, Oregon: U.S. Geological Survey Geologic Quadrangle Map 1653, scale 1:62,500, 1 sheet.

Smith, James G., Page, N.J., Johnson, M.G., Moring, B.C., and Gray, Floyd, 1982, Preliminary geologic map of the Medford $1^{\circ}$ by $2^{\circ}$ Quadrangle, Oregon and California: U.S. Geological Survey Open-File Report 82-955, scale 1:250,000.

Sorenson, S.K., and Schwarzbach, S.E., 1991,

Reconnaissance investigations of water quality, bottom sediment, and biota associated with irrigation drainage in the Klamath Basin California and Oregon, 1988-89: U.S. Geological Survey Water-Resources Investigations Report 90-4203, 64 p.

Stephens, J.C., 1956, Subsidence of organic soils in the Florida Everglades, Soil Science Society of America Proceedings, v. 20, p. 77-80.

U.S. Army Corp of Engineers, 1979, Klamath River Basin-Oregon-Reconnaissance report: San Francisco, California, U.S. Army Corps of Engineers, $175 \mathrm{p}$.

1982, Potential eutrophication control measures for Upper Klamath Lake, Oregon-Data evaluation and experimental design: San Francisco, California, $200 \mathrm{p}$.

U.S. Department of Agriculture, 1975, Soil taxonomy-A basic system of soil classification for making and interpreting soil surveys: Soil Conservation Service Agriculture Handbook no. 436, 754 p. 1991, Soil Survey Laboratory Methods Manual: Lincoln, Nebraska, National Soil Survey Center, 
Soil Conservation Service Soil Survey Investigations Report No. 42 Version 1.0, 603 p.

1996, Soil Survey Laboratory Methods Manual: Lincoln, Nebraska, National Soil Survey Center, Natural Resources Conservation Service Soil Survey Investigations Report No. 42 Version 3.0, 693 p.

Voznjuk, S.T., Olinevich, V.A., and Lyko, D.V., 1988, The rational use of peat soils in agricultural production: Proceedings of the 8th International Peat Congress, Volume 3, Leningrad, USSR, August 14-21, 1988, p. 18-24.

Walbridge, M.R., 1991, Phosphorus availability in acid organic soils of the lower North Carolina coastal plain: Ecology, v. 72, no. 6, p. 2083-2100.
Walker, G.W., 1951, Pumice deposits of the Klamath Indian Reservation Klamath County, Oregon: U.S. Geological Survey Circular 128, 6 p.

Williams, Howell, 1965, The geology of Crater Lake National Park, Oregon, in Peterson, N.V., and Groh, E.A., eds., State of Oregon lunar geological field conference guide book: Oregon Department of Geology and Mineral Industries Bulletin 57, p. 39-51.

Wood, T.M., Fuhrer, G.J., and Morace, J.L., 1996, Relation between selected water-quality variables and lake level in Upper Klamath and Agency Lakes, Oregon: U.S. Geological Survey Water-Resources Investigations Report 96-4079, 57 p. 


\section{APPENDIX I}

QUALITY ASSURANCE 


\section{APPENDIX I. QUALITY ASSURANCE}

Quality assurance of the collection, preparation, and analysis of soil and water samples was accomplished with the use of replicate split samples. Replicate split samples are prepared by dividing a single sample into a pair of identical samples (replicates) at the time and place of sampling. The replicate samples are processed and preserved in the same manner. The purpose of analyzing replicate samples was to assess analytical precision - assuming no contamination or other differences caused by sample processing, preservation, or transport. The relative percent difference (RPD) was used as a measure of how well the analyses of the split samples compared:

$$
R P D=\left|\frac{(\text { Sample } 1-\text { Sample } 2)}{(\text { Sample } 1+\text { Sample } 2) / 2} \times 100\right|
$$

where:

$R P D=$ relative percent difference (dimensionless),

Sample $1=$ the constituent concentration or other measurement for the first sample of a replicate pair, and

Sample $2=$ the constituent concentration or other measurement for the second sample of a replicate pair.

\section{Water-Quality Samples}

Quality-assurance data were used, to the degree possible, to quantify precision in the water-quality samples collected during this study for the analysis of nutrients. By collecting replicate split samples from the churn splitter, the results give an indication of the precision involved in the splitting of the samples, the handling and processing of the samples, and the laboratory analyses run on the samples. Because the quality-assurance data for this study are few in number, a comprehensive analysis was precluded. Statistics generated from the quality-assurance data were used, however, in the interpretation of the data and should be consulted by other users.

The RPD was calculated for all replicate split samples as an indicator of precision (table I-A).
Twenty-five percent of the quality-assurance data had an RPD of 0 percent, indicating that both samples had the same constituent concentration. In general, the RPDs were less than 20 percent, with over threefourths of the differences less than 10 percent. All constituents, except phosphorus in unfiltered water and nitrite in filtered water, appear to follow the commonly occurring pattern of decreasing RPD as concentration is increasing. In general, however, the absolute differences are approximately constant. For phosphorus and ammonia plus organic nitrogen in unfiltered water, there is no apparent pattern, but the differences could partly reflect how well the churn was able to split particulates in samples. Also, both of these analyses involve digestions that typically contribute to analytical error. For nitrite in filtered water, all RPD values for detectable concentrations were zero, indicating good precision across the concentration range. Overall, these replicate data show that sampling and analytical variation were not great enough to affect the conclusions of this report.

\section{Soil Samples}

The Colorado State University Soil, Water and Plant Testing Laboratory used for physical and chemical analyses was reviewed by the USGS Branch of Technical Development and Quality Systems and was rated as satisfactory (L.J. Schroder, U.S. Geological Survey, written commun., 1996). About 11 percent of the soil samples submitted and analyzed for this study were for quality assurance and consisted of 22 replicate split samples. The RPD was calculated to examine the magnitude of the difference between concentrations and other measurements in the sample pairs (table I-B).

With the exception of the analyses for total carbon and nitrite plus nitrate, the mean RPD for all analyses was less than 10 percent. The total carbon and nitrite plus nitrate analyses had mean RPDs of 15.8 and 30.7 percent respectively, however, these analyses were not used in the interpretations for this report.

Obtaining identical samples from splitting of soil materials is difficult because of the heterogeneous nature of the soil and clumping. In addition, some chemical species may not be evenly distributed within the soil. However, overall, these replicate data show that sampling and analytical variation were not great enough to affect the conclusions of this report. 
Table I-A. Quality-assurance data for nutrients in water-quality samples collected at pumping stations and a flowing artesian well adjacent to Upper Klamath Lake, Oregon, 1993-95

[All concentrations reported are from filtered-water samples, unless otherwise stated. Concentrations are reported as nitrogen or phosphorus. Relative percent difference, absolute value of the difference between the split samples divided by the mean and multiplied by $100 . *$, both concentrations were below the minimum reporting level. <, less than]

\begin{tabular}{|c|c|c|c|c|c|c|c|c|c|c|}
\hline \multicolumn{3}{|c|}{ Sample description } & \multicolumn{5}{|c|}{ Nitrogen (milligrams per liter) } & \multicolumn{3}{|c|}{ Phosphorus (milligrams per liter) } \\
\hline Pumping station & Date & Time & Ammonia & $\begin{array}{c}\text { Ammonia } \\
\text { plus } \\
\text { organic } \\
\text { nitrogen }\end{array}$ & $\begin{array}{c}\text { Ammonia } \\
\text { plus } \\
\text { organic } \\
\text { nitrogen, } \\
\text { unfiltered }\end{array}$ & Nitrite & $\begin{array}{l}\text { Nitrite } \\
\text { plus } \\
\text { nitrate }\end{array}$ & $\begin{array}{l}\text { Phosphorus, } \\
\text { unfiltered }\end{array}$ & Phosphorus & Orthophosphate \\
\hline
\end{tabular}

Wocus Marsh

$\begin{array}{rrr}03-16-95 & 1340 & 0.15 \\ 03-16-95 & 1330 & .15\end{array}$

Relative percent difference

Williamson River North

Williamson River North

04-04-95

Relative percent difference

Northwest Agency Lake

Northwest Agency Lake

05-14-93

05-14-93

1330

Relative percent difference

Northwest Agency Lake

Northwest Agency Lake

\section{4-19-95}

04-19-95

1100

1115

1.6

1.9

17

Relative percent difference

Wood River Property (Corral)

Wood River Property (Corral)

06-23-95

Relative percent difference

$\begin{array}{ll}1645 & .030 \\ 1645 & .030\end{array}$

.030

0

\section{Pumping stations}

\begin{tabular}{|c|c|c|c|c|c|}
\hline 4.3 & 0.020 & 0.41 & 0.10 & 0.060 & 0.020 \\
\hline 4.1 & .020 & .42 & .10 & .050 & .020 \\
\hline 4.8 & 0 & 2.4 & 0 & 18 & 0 \\
\hline 4.9 & .020 & .11 & 1.0 & .80 & .64 \\
\hline 4.0 & .020 & .10 & .80 & .79 & .63 \\
\hline 6.1 & 0 & 9.5 & 22 & 1.2 & 1.6 \\
\hline 2.5 & $<.010$ & $<.005$ & .39 & .20 & .19 \\
\hline 2.5 & $<.010$ & $<.005$ & .38 & .23 & .19 \\
\hline 0 & $*$ & $*$ & 2.6 & 14 & 0 \\
\hline 2.6 & .010 & .033 & .30 & .22 & .19 \\
\hline 3.2 & .010 & .029 & .35 & .23 & .20 \\
\hline 4.4 & 0 & 13 & 15 & 4.4 & 5.1 \\
\hline 2.9 & .020 & $<.005$ & 1.0 & .82 & .82 \\
\hline 2.5 & .020 & $<.005$ & .97 & .83 & .83 \\
\hline 15 & 0 & $*$ & 3.0 & 1.2 & 1.2 \\
\hline
\end{tabular}

Flowing artesian well

Flowing artesian well \#1

05-24-95

Flowing artesian well \#1

05-24-95

1045
1120

5.7
5.8
1.7

5.7
5.6

$\begin{array}{ll}5.6 & <.010 \\ 5.7 & <.010 \\ 1.8 & *\end{array}$

\section{$<.005$}

$<.005$

6.4

6.4

6.8
6.5

6.6

1.8

$*$

0

.19

.82

1.2

Relative percent difference

1.7


Table I-B. Quality-assurance data for analyses of soil samples collected from wetlands adjacent to Upper Klamath Lake, Oregon, August 1995

[Relative percent difference, absolute value of the difference between split samples divided by the mean and multiplied by $100 . *$, both concentrations were below the minimum reporting level. --, not analyzed or not applicable; <, less than; see plates 1 and 2 for sample locations]

Abbreviations used in sample name:

$\begin{array}{lll}\text { ALW } & \text { Agency Lake West } & \\ \text { BBS } & \text { Ball Bay South } & \\ \text { CAM } & \text { Caledonia Marsh } & \\ \text { COV } & \text { Cove Point } & \\ \text { HNK } & \text { Hanks Marsh Unit-_ } & \\ & \text { Upper Klamath National Wildlife Refuge }\end{array}$

MCC McCornack Point

PUD Replicate Split Sample

WOC Wocus Marsh

WRN Williamson River North

WRR Wood River Property

\begin{tabular}{|c|c|c|c|c|c|c|}
\hline Sample name & $\begin{array}{l}\text { Percent } \\
\text { ash }\end{array}$ & $\begin{array}{c}\text { Total } \\
\text { carbon } \\
\text { (as } \\
\text { percent } \\
\text { dry } \\
\text { mass) }\end{array}$ & $\begin{array}{c}\text { Inorganic } \\
\text { carbon } \\
\text { (as } \\
\text { percent } \\
\text { dry } \\
\text { mass) }\end{array}$ & $\begin{array}{c}\text { Total } \\
\text { nitrogen } \\
\text { (as } \\
\text { percent } \\
\text { dry } \\
\text { mass) }\end{array}$ & $\begin{array}{c}\text { Nitrite } \\
\text { plus } \\
\text { nitrate } \\
\text { as N } \\
\text { (mg/kg) }\end{array}$ & $\begin{array}{c}\text { Total } \\
\text { phosphorus } \\
(\mathrm{mg} / \mathrm{kg})\end{array}$ \\
\hline ALW-03C & 35.5 & 35.3 & -- & 1.87 & 289 & 240 \\
\hline PUD-08B & 39.1 & 34.1 & -- & 1.81 & 128 & 260 \\
\hline Relative percent difference & 9.7 & 3.5 & -- & 3.3 & 77.2 & 8.0 \\
\hline ALW-04A & 27.4 & 38.3 & -- & 2.63 & 250 & 910 \\
\hline PUD-09A & 27.4 & 39.2 & -- & 2.83 & 127 & 1,080 \\
\hline Relative percent difference & .0 & 2.3 & -- & 7.3 & 65.3 & 17.1 \\
\hline BBS-01B & 86.4 & 3.8 & -- & .50 & 23 & 310 \\
\hline PUD-09G & 86.4 & 3.7 & -- & .49 & 21 & 310 \\
\hline Relative percent difference & .0 & 2.7 & -- & 2.0 & 9.1 & .0 \\
\hline CAM-01C & 9.2 & 52.5 & -- & 2.06 & 23 & 300 \\
\hline PUD-07E & 8.8 & 53.0 & -- & 2.05 & 20 & 310 \\
\hline Relative percent difference & 4.4 & .9 & -- & .5 & 14.0 & 3.3 \\
\hline CAM-01F & 76.7 & 11.1 & -- & 1.00 & 200 & 210 \\
\hline PUD-07A & 76.2 & 11.8 & -- & 1.09 & 273 & 230 \\
\hline Relative percent difference & .7 & 6.1 & -- & 8.6 & 30.9 & 9.1 \\
\hline CAM-02A & 82.4 & 5.7 & $<.01$ & .56 & 33 & 340 \\
\hline PUD-02A & 82.7 & 5.2 & $<.01$ & .61 & 27 & 370 \\
\hline Relative percent difference & .4 & 9.2 & $*$ & 8.5 & 20.0 & 8.5 \\
\hline CAM-02B & 88.1 & 4.0 & $<.01$ & .29 & 25 & 120 \\
\hline PUD-02B & 89.2 & 3.4 & $<.01$ & .28 & 20 & 130 \\
\hline Relative percent difference & 1.2 & 16.2 & $*$ & 3.5 & 22.2 & 8.0 \\
\hline CAM-03A & 33.3 & 36.5 & -- & 1.74 & 53 & 480 \\
\hline PUD-05C & 35.0 & 34.3 & $<.01$ & 1.69 & 42 & 390 \\
\hline PUD-09B & 35.9 & 38.1 & -- & 1.93 & 59 & 510 \\
\hline Relative percent difference & 2.8 & 3.7 & -- & 5.3 & 12.1 & 10.1 \\
\hline CAM-03B & 21.5 & 42.0 & -- & 3.00 & 36 & 470 \\
\hline PUD-08C & 20.3 & 44.2 & -- & 3.05 & 29 & 500 \\
\hline Relative percent difference & 5.7 & 5.1 & -- & 1.7 & 21.5 & 6.2 \\
\hline CAM-03C & 75.5 & 11.8 & -- & 1.07 & 29 & 150 \\
\hline PUD-07C & 74.9 & 12.8 & -- & 1.13 & 28 & 180 \\
\hline Relative percent difference & .8 & 8.1 & -- & 5.5 & 3.5 & 18.2 \\
\hline
\end{tabular}


Table I-B. Quality-assurance data for analyses of soil samples collected from wetlands adjacent to Upper Klamath Lake, Oregon, August 1995-Continued

\begin{tabular}{|c|c|c|c|c|c|c|}
\hline Sample name & $\begin{array}{c}\text { Percent } \\
\text { ash }\end{array}$ & $\begin{array}{c}\text { Total } \\
\text { carbon } \\
\text { (as } \\
\text { percent } \\
\text { dry } \\
\text { mass) }\end{array}$ & $\begin{array}{l}\text { Inorganic } \\
\text { carbon } \\
\text { (as } \\
\text { percent } \\
\text { dry } \\
\text { mass) }\end{array}$ & $\begin{array}{c}\text { Total } \\
\text { nitrogen } \\
\text { (as } \\
\text { percent } \\
\text { dry } \\
\text { mass) }\end{array}$ & $\begin{array}{c}\text { Nitrite } \\
\text { plus } \\
\text { nitrate } \\
\text { as N } \\
\text { (mg/kg) }\end{array}$ & $\begin{array}{c}\text { Total } \\
\text { phosphorus } \\
(\mathrm{mg} / \mathrm{kg})\end{array}$ \\
\hline CAM-04A & 63.5 & 16.7 & 0.02 & 1.06 & 66 & 870 \\
\hline PUD-05B & 63.4 & 17.6 & .02 & .89 & 83 & 830 \\
\hline Relative percent difference & .2 & 5.2 & .0 & 17.4 & 22.8 & 4.7 \\
\hline CAM-04D & 93.7 & .9 & $<.01$ & .06 & 7 & 270 \\
\hline PUD-05A & 94.0 & .6 & $<.01$ & .05 & 22 & 320 \\
\hline Relative percent difference & .3 & 40.0 & $*$ & 18.2 & 103.4 & 16.9 \\
\hline COV-01A & 72.3 & 13.5 & -- & 1.02 & 34 & 410 \\
\hline PUD-09D & 71.3 & 13.7 & -- & .95 & 27 & 470 \\
\hline Relative percent difference & 1.4 & 1.5 & -- & 7.1 & 23.0 & 13.6 \\
\hline COV-02B & 38.4 & 35.0 & -- & 2.17 & 104 & 390 \\
\hline PUD-08E & 36.1 & 35.7 & -- & 2.18 & 100 & 440 \\
\hline Relative percent difference & 6.2 & 2.0 & -- & .5 & 3.9 & 12.0 \\
\hline HNK-03B & 25.7 & 41.9 & -- & 2.82 & 34 & 490 \\
\hline PUD-09E & 26.6 & 40.1 & -- & 2.65 & 31 & 500 \\
\hline Relative percent difference & 3.4 & 4.4 & -- & 6.2 & 9.2 & 2.0 \\
\hline MCC-01A & 89.7 & 2.6 & $<.01$ & .25 & 13 & 200 \\
\hline PUD-02D & 89.0 & 3.1 & $<.01$ & .25 & 11 & 220 \\
\hline Relative percent difference & .8 & 17.5 & $*$ & .0 & 16.7 & 9.5 \\
\hline WOC-02A & 63.1 & 14.0 & $<.01$ & 1.48 & 301 & 770 \\
\hline PUD-06B & 62.0 & 16.3 & $<.01$ & 1.37 & 314 & 780 \\
\hline Relative percent difference & 1.8 & 15.2 & $*$ & 7.7 & 4.2 & 1.3 \\
\hline WOC-07C & 97.8 & .0 & .15 & .01 & 17 & 130 \\
\hline PUD-06D & 99.1 & .2 & .17 & .01 & 7 & 150 \\
\hline Relative percent difference & 1.3 & 181.0 & 12.5 & .0 & 83.3 & 14.3 \\
\hline WRN-01A & 53.3 & 24.4 & -- & 1.84 & 71 & 1070 \\
\hline WRN-01B & 52.8 & 24.3 & -- & 1.83 & 95 & 1060 \\
\hline Relative percent difference & .9 & .4 & & .5 & 28.9 & .9 \\
\hline WRN-01C & 57.3 & 17.8 & $<.01$ & 1.53 & 129 & 640 \\
\hline PUD-02C & 62.4 & 15.5 & $<.01$ & 1.45 & 109 & 590 \\
\hline Relative percent difference & 8.5 & 13.8 & $*$ & 5.4 & 16.8 & 8.1 \\
\hline WRN-03C & 89.5 & 2.71 & -- & .22 & 6 & 420 \\
\hline PUD-09C & 90.2 & 2.9 & -- & .23 & 5 & 400 \\
\hline Relative percent difference & .8 & 7.1 & -- & 4.4 & 18.2 & 4.9 \\
\hline WRR-05B & 66.2 & 18.3 & -- & 1.46 & 29 & 740 \\
\hline PUD-09H & 64.9 & 18.7 & -- & 1.42 & 14 & 780 \\
\hline Relative percent difference & 2.0 & 2.2 & -- & 2.8 & 69.8 & 5.3 \\
\hline Mean relative percent difference & 2.4 & 15.8 & 6.3 & 5.3 & 30.7 & 8.3 \\
\hline
\end{tabular}




\section{APPENDIX II}

LOCATION AND DEPTH OF SOIL CORES 
Appendix II. Location and depth of soil cores

[Longitude and latitude for 1993 cores are approximate and were determined from U.S. Geological Survey 1:24,000 scale topographic maps; longitude and latitude for 1995 cores were determined using a high precision Global Positioning System (GPS) and are accurate to about +/- 50 feet; datum is the 1927 North American Datum]

Abbreviations used in sample name:

$\begin{array}{ll}\text { ALG } & \text { Algoma } \\ \text { ALN } & \text { Agency Lake North } \\ \text { ALW } & \text { Agency Lake West } \\ \text { BBS } & \text { Ball Bay South } \\ \text { BBW } & \text { Ball Bay West } \\ \text { CAM } & \text { Caledonia Marsh } \\ \text { COV } & \text { Cove Point } \\ \text { HNK } & \text { Hanks Marsh Unit_- }\end{array}$

HNK Hanks Marsh Unit-

Upper Klamath National Wildlife Refuge

1993 Cores

\begin{tabular}{llll}
\hline Core & $\begin{array}{c}\text { Total depth } \\
\text { (feet) }\end{array}$ & Longitude & Latitude
\end{tabular}

\begin{tabular}{lrll}
\hline ALW-A1 & 13.08 & $121^{\circ} 58^{\prime} 47^{\prime \prime}$ & $42^{\circ} 33^{\prime} 53^{\prime \prime}$ \\
CAM-A1 & 14.00 & $121^{\circ} 54^{\prime} 19^{\prime \prime}$ & $42^{\circ} 18^{\prime} 43 "$ \\
CAM-A2 & 14.00 & $121^{\circ} 54^{\prime} 04^{\prime \prime}$ & $42^{\circ} 17^{\prime} 49^{\prime \prime}$ \\
CAM-A3 & 13.50 & $121^{\circ} 53^{\prime} 49^{\prime \prime}$ & $42^{\circ} 17^{\prime} 25^{\prime \prime}$ \\
NWR-A1 & 21.67 & $122^{\circ} 04^{\prime} 19^{\prime \prime}$ & $42^{\circ} 27^{\prime} 60^{\prime \prime}$ \\
NWR-A2 & 22.33 & $122^{\circ} 04^{\prime} 38^{\prime \prime}$ & $42^{\circ} 28^{\prime} 03^{\prime \prime}$ \\
WOC-A1 & 18.00 & $121^{\circ} 55^{\prime} 34^{\prime \prime}$ & $42^{\circ} 16^{\prime} 47^{\prime \prime}$ \\
WOC-A2 & 5.67 & $121^{\circ} 53^{\prime} 09^{\prime \prime}$ & $42^{\circ} 15^{\prime} 23^{\prime \prime}$ \\
WRN-A1 & 5.33 & $121^{\circ} 57^{\prime} 22^{\prime \prime}$ & $42^{\circ} 30^{\prime} 01 "$ \\
WRN-A2 & 5.58 & $121^{\circ} 57^{\prime} 45^{\prime \prime}$ & $42^{\circ} 30^{\prime} 01^{\prime \prime}$ \\
WRN-A3 & 5.67 & $121^{\circ} 58^{\prime} 46^{\prime \prime}$ & $42^{\circ} 29^{\prime} 60^{\prime \prime}$ \\
WRR-A1 & 12.17 & $121^{\circ} 58^{\prime} 04^{\prime \prime}$ & $42^{\circ} 35^{\prime} 04^{\prime \prime}$ \\
WRR-A2 & 12.83 & $121^{\circ} 58^{\prime} 10^{\prime \prime}$ & $42^{\circ} 35^{\prime} 04^{\prime \prime}$ \\
WRR-A3 & 5.50 & $121^{\circ} 57^{\prime} 24^{\prime \prime}$ & $42^{\circ} 36^{\prime} 15^{\prime \prime}$ \\
WRR-A4 & 2.00 & $121^{\circ} 58^{\prime} 12^{\prime \prime}$ & $42^{\circ} 37^{\prime} 13^{\prime \prime}$
\end{tabular}

\begin{tabular}{lcll}
\hline \multicolumn{3}{c}{ 1995 Cores } \\
\hline $\begin{array}{c}\text { Core } \\
\text { Name }\end{array}$ & $\begin{array}{c}\text { Total depth } \\
\text { (feet) }\end{array}$ & Longitude & Latitude \\
\hline ALG-01 & 6.10 & $121^{\circ} 49^{\prime} 10^{\prime \prime}$ & $42^{\circ} 20^{\prime} 53^{\prime \prime}$ \\
ALG-02 & 7.80 & $121^{\circ} 49^{\prime} 09^{\prime \prime}$ & $42^{\circ} 21^{\prime} 46^{\prime \prime}$ \\
ALG-03 & 10.20 & $121^{\circ} 48^{\prime} 39^{\prime \prime}$ & $42^{\circ} 22^{\prime} 50^{\prime \prime}$ \\
ALG-04 & 6.80 & $121^{\circ} 48^{\prime} 19^{\prime \prime}$ & $42^{\circ} 22^{\prime} 06^{\prime \prime}$ \\
ALG-05 & 4.00 & $121^{\circ} 48^{\prime} 29^{\prime \prime}$ & $42^{\circ} 21^{\prime} 24^{\prime \prime}$ \\
ALN-01 & 13.60 & $121^{\circ} 58^{\prime} 27^{\prime \prime}$ & $42^{\circ} 34^{\prime} 52^{\prime \prime}$ \\
ALN-02 & 13.60 & $121^{\circ} 59^{\prime} 24^{\prime \prime}$ & $42^{\circ} 34^{\prime} 38^{\prime \prime}$ \\
ALN-03 & 10.20 & $122^{\circ} 00^{\prime} 26^{\prime \prime}$ & $42^{\circ} 34^{\prime} 41^{\prime \prime}$ \\
ALN-04 & 11.90 & $121^{\circ} 59^{\prime} 46^{\prime \prime}$ & $42^{\circ} 36^{\prime} 04^{\prime \prime}$ \\
ALW-01 & 13.60 & $122^{\circ} 00^{\prime} 49^{\prime \prime}$ & $42^{\circ} 31^{\prime} 59^{\prime \prime}$ \\
ALW-02 & 10.20 & $121^{\circ} 58^{\prime} 36^{\prime \prime}$ & $42^{\circ} 32^{\prime} 48^{\prime \prime}$ \\
ALW-03 & 10.20 & $121^{\circ} 59^{\prime} 51^{\prime \prime}$ & $42^{\circ} 33^{\prime} 34^{\prime \prime}$ \\
ALW-04 & 11.90 & $121^{\circ} 59^{\prime} 45^{\prime \prime}$ & $42^{\circ} 32^{\prime} 59^{\prime \prime}$ \\
BBS-01 & 4.00 & $122^{\circ} 00^{\prime} 13^{\prime \prime}$ & $42^{\circ} 23^{\prime} 02^{\prime \prime}$ \\
BBS-02 & 4.80 & $122^{\circ} 00^{\prime} 11^{\prime \prime}$ & $42^{\circ} 23^{\prime} 33^{\prime \prime}$ \\
BBW-01 & 4.50 & $122^{\circ} 02^{\prime} 51^{\prime \prime}$ & $42^{\circ} 24^{\prime} 24^{\prime \prime}$ \\
BBW-02 & 13.60 & $122^{\circ} 02^{\prime} 12^{\prime \prime}$ & $42^{\circ} 24^{\prime} 33^{\prime \prime}$ \\
CAM-01 & 10.20 & $121^{\circ} 55^{\prime} 12^{\prime \prime}$ & $42^{\circ} 18^{\prime} 33^{\prime \prime}$ \\
CAM-02 & 10.00 & $121^{\circ} 53^{\prime} 41^{\prime \prime}$ & $42^{\circ} 18^{\prime} 52^{\prime \prime}$ \\
& & & \\
& & &
\end{tabular}

MCC McCornack Point

NWR Northwest Upper Klamath LakeUpper Klamath National Wildlife Refuge

SHO Shoalwater Bay Wildlife Area

SQW Squaw Point Wildlife Area

WOC Wocus Marsh

WRM Wood River Marsh

WRN Williamson River North

WRR Wood River Property

\begin{tabular}{|c|c|c|c|}
\hline \multicolumn{4}{|c|}{1995 Cores - Continued } \\
\hline $\begin{array}{l}\text { Core } \\
\text { Name }\end{array}$ & $\begin{array}{l}\text { Total depth } \\
\text { (feet) }\end{array}$ & Longitude & Latitude \\
\hline CAM-03 & 6.80 & $121^{\circ} 53 ’ 31^{\prime \prime}$ & $42^{\circ} 18^{\prime} 15^{\prime \prime}$ \\
\hline CAM-04 & 3.00 & $121^{\circ} 52^{\prime} 50^{\prime \prime}$ & $42^{\circ} 17 ’ 30^{\prime \prime}$ \\
\hline CAM-05 & 3.40 & $121^{\circ} 53$ '22" & $42^{\circ} 17^{\prime} 04^{\prime \prime}$ \\
\hline CAM-06 & 11.90 & $121^{\circ} 5528^{\prime \prime}$ & $42^{\circ} 17^{\prime} 43^{\prime \prime}$ \\
\hline CAM-07 & 6.80 & $121^{\circ} 54^{\prime} 42^{\prime \prime}$ & $42^{\circ} 17^{\prime} 13^{\prime \prime}$ \\
\hline CAM-08 & 18.70 & $121^{\circ} 55^{\prime} 27^{\prime \prime}$ & $42^{\circ} 17^{\prime} 05^{\prime \prime}$ \\
\hline COV-01 & 9.40 & $121^{\circ} 49^{\prime} 37^{\prime \prime}$ & $42^{\circ} 17 ’ 36^{\prime \prime}$ \\
\hline COV-02 & 7.40 & $121^{\circ} 49^{\prime} 04^{\prime \prime}$ & $42^{\circ} 17^{\prime} 35^{\prime \prime}$ \\
\hline HNK-01 & 18.80 & $121^{\circ} 49^{\prime} 14^{\prime \prime}$ & $42^{\circ} 18^{\prime} 11^{\prime \prime}$ \\
\hline HNK-02 & 11.90 & $121^{\circ} 49^{\prime} 40^{\prime \prime}$ & $42^{\circ} 18^{\prime} 11^{\prime \prime}$ \\
\hline HNK-03 & 11.20 & $121^{\circ} 49^{\prime} 20^{\prime \prime}$ & $42^{\circ} 19^{\prime} 38^{\prime \prime}$ \\
\hline MCC-01 & 3.40 & $121^{\circ} 50^{\prime} 39^{\prime \prime}$ & $42^{\circ} 15^{\prime} 19^{\prime \prime}$ \\
\hline MCC-02 & 2.30 & $121^{\circ} 51^{\prime} 03^{\prime \prime}$ & $42^{\circ} 15^{\prime} 58^{\prime \prime}$ \\
\hline MCC-03 & 2.60 & $121^{\circ} 511^{\prime} 17^{\prime \prime}$ & $42^{\circ} 15^{\prime} 30^{\prime \prime}$ \\
\hline NWR-01 & 18.70 & $122^{\circ} 00^{\prime} 31^{\prime \prime}$ & $42^{\circ} 31^{\prime} 47^{\prime \prime}$ \\
\hline NWR-02 & 17.00 & $122^{\circ} 02 ’ 23^{\prime \prime}$ & $42^{\circ} 31^{\prime} 47^{\prime \prime}$ \\
\hline NWR-03 & 11.90 & $122^{\circ} 02 ’ 56^{\prime \prime}$ & $42^{\circ} 26^{\prime} 01^{\prime \prime}$ \\
\hline SHO-01 & 14.20 & $121^{\circ} 57^{\prime} 33^{\prime \prime}$ & $42^{\circ} 23 ’ 38^{\prime \prime}$ \\
\hline SQW-01 & 9.70 & $121^{\circ} 54^{\prime} 34^{\prime \prime}$ & $42^{\circ} 21^{\prime} 04^{\prime \prime}$ \\
\hline WOC-01 & 3.50 & $121^{\circ} 53^{\prime} 03^{\prime \prime}$ & $42^{\circ} 16^{\prime} 02^{\prime \prime}$ \\
\hline WOC-02 & 5.10 & $121^{\circ} 54^{\prime} 02^{\prime \prime}$ & $42^{\circ} 16^{\prime} 18^{\prime \prime}$ \\
\hline WOC-03 & 6.80 & $121^{\circ} 54^{\prime} 49^{\prime \prime}$ & $42^{\circ} 15^{\prime} 56^{\prime \prime}$ \\
\hline WOC-04 & 6.80 & $121^{\circ} 53 ’ 56^{\prime \prime}$ & $42^{\circ} 1521^{\prime \prime}$ \\
\hline WOC-05 & 5.30 & $121^{\circ} 53^{\prime} 04^{\prime \prime}$ & $42^{\circ} 14^{\prime} 44^{\prime \prime}$ \\
\hline WOC-06 & 3.90 & $121^{\circ} 52^{\prime} 05^{\prime \prime}$ & $42^{\circ} 14^{\prime} 45^{\prime \prime}$ \\
\hline WOC-07 & 2.00 & $121^{\circ} 52^{\prime} 03^{\prime \prime}$ & $42^{\circ} 13^{\prime} 60^{\prime \prime}$ \\
\hline WOC-08 & 3.50 & $121^{\circ} 51^{\prime} 45^{\prime \prime}$ & $42^{\circ} 15^{\prime} 10^{\prime \prime}$ \\
\hline WRM-01 & 10.60 & $121^{\circ} 56^{\prime} 11^{\prime \prime}$ & $42^{\circ} 34^{\prime} 52^{\prime \prime}$ \\
\hline WRM-02 & 12.20 & $121^{\circ} 56^{\prime} 18^{\prime \prime}$ & $42^{\circ} 35^{\prime} 13^{\prime \prime}$ \\
\hline WRN-01 & 10.20 & $121^{\circ} 58^{\prime} 31^{\prime \prime}$ & $42^{\circ} 28^{\prime} 58^{\prime \prime}$ \\
\hline WRN-02 & 6.30 & $121^{\circ} 57^{\prime} 26^{\prime \prime}$ & $42^{\circ} 28^{\prime} 50^{\prime \prime}$ \\
\hline WRN-03 & 8.20 & $121^{\circ} 57^{\prime} 03^{\prime \prime}$ & $42^{\circ} 29^{\prime} 34^{\prime \prime}$ \\
\hline WRR-01 & 6.40 & $121^{\circ} 56^{\prime} 47^{\prime \prime}$ & $42^{\circ} 35^{\prime} 55^{\prime \prime}$ \\
\hline WRR-02 & 7.90 & $121^{\circ} 56^{\prime} 50^{\prime \prime}$ & $42^{\circ} 35^{\prime} 01^{\prime \prime}$ \\
\hline WRR-03 & 18.30 & $121^{\circ} 58^{\prime} 58^{\prime \prime}$ & $42^{\circ} 35^{\prime} 42^{\prime \prime}$ \\
\hline WRR-04 & 11.20 & $121^{\circ} 59^{\prime} 53^{\prime \prime}$ & $42^{\circ} 3629^{\prime \prime}$ \\
\hline WRR-05 & 5.40 & $121^{\circ} 58^{\prime} 58^{\prime \prime}$ & $42^{\circ} 36 ’ 51^{\prime \prime}$ \\
\hline WRR-06 & 2.80 & $121^{\circ} 58^{\prime} 07^{\prime \prime}$ & $42^{\circ} 37^{\prime} 11^{\prime \prime}$ \\
\hline WRR-07 & 2.00 & $121^{\circ} 57^{\prime} 28^{\prime \prime}$ & $42^{\circ} 3631^{\prime \prime}$ \\
\hline WRR-08 & 10.00 & $121^{\circ} 57^{\prime} 50^{\prime \prime}$ & $42^{\circ} 36^{\prime} 12^{\prime \prime}$ \\
\hline WRR-09 & 11.90 & $121^{\circ} 58^{\prime} 08^{\prime \prime}$ & $42^{\circ} 35^{\prime} 04^{\prime \prime}$ \\
\hline WRR-10 & 11.70 & $121^{\circ} 57 ’ 22^{\prime \prime}$ & $42^{\circ} 35^{\prime} 31^{\prime \prime}$ \\
\hline
\end{tabular}




\section{APPENDIX III \\ DESCRIPTION OF SOIL SAMPLES \\ AND \\ SUMMARY OF PHYSICAL AND CHEMICAL ANALYSES}


Appendix III. Description of soil samples and summary of physical and chemical analyses

[-, not available; D, Davis soil auger; L, large Macaulay peat sampler; S, small Macaulay peat sampler; ft, feet; cm, centimeter; mL, milliliters; g, grams; mg, milligrams; kg, kilogram ]

Abbreviations used in sample name:

$\begin{array}{lllcll}\text { ALG } & \text { Algoma } & \text { COV } & \text { Cove Point } & \text { SHO } & \text { Shoalwater Bay Wildlife Area } \\ \text { ALN } & \text { Agency Lake North } & \text { HNK } & \text { Hanks Marsh Unit-- } & \text { SQW } & \text { Squaw Point Wildlife Area } \\ \text { ALW } & \text { Agency Lake West } & & \text { Upper Klamath National Wildlife Refuge } & \text { WOC } & \text { Wocus Marsh } \\ \text { BBS } & \text { Ball Bay South } & \text { MCC } & \text { McCornack Point } & \text { WRM } & \text { Wood River Marsh } \\ \text { BBW } & \text { Ball Bay West } & \text { NWR } & \text { Northwest Upper Klamath Lake-- } & \text { WRN } & \text { Williamson River North } \\ \text { CAM } & \text { Caledonia Marsh } & & \text { Upper Klamath National Wildlife Refuge } & \text { WRR } & \text { Wood River Property }\end{array}$

\begin{tabular}{|c|c|c|c|c|c|c|c|c|c|c|c|c|c|c|c|c|c|c|c|}
\hline $\begin{array}{c}\text { Sample } \\
\text { name }\end{array}$ & $\begin{array}{l}\text { San } \\
\text { def } \\
\text { (f } \\
\text { Top }\end{array}$ & $\begin{array}{l}\text { nple } \\
\text { oth } \\
\text { t) } \\
\text { Bottom }\end{array}$ & $\begin{array}{l}\text { Length } \\
\text { of sample } \\
\text { interval } \\
\text { (ft) }\end{array}$ & $\begin{array}{c}\text { Volume } \\
(\mathrm{mL})\end{array}$ & $\begin{array}{l}\text { Sample } \\
\text { method }\end{array}$ & Soil material & $\begin{array}{l}\text { Sample } \\
\text { weight } \\
\text { as } \\
\text { received } \\
\text { (g) }\end{array}$ & $\begin{array}{c}\text { Sample } \\
\text { weight } \\
\text { dry } \\
\text { (g) }\end{array}$ & $\begin{array}{c}\text { Bulk } \\
\text { density } \\
\text { (g per } \\
\text { cubic cm) }\end{array}$ & $\begin{array}{c}\text { Percent } \\
\text { moisture, } \\
\text { as } \\
\text { percentage } \\
\text { of } \\
\text { total mass }\end{array}$ & $\begin{array}{c}\text { Percent } \\
\text { dry matter, } \\
\text { as } \\
\text { percentage } \\
\text { of } \\
\text { total mass }\end{array}$ & $\begin{array}{l}\text { Percent } \\
\text { ash } \\
\text { content, } \\
\text { as } \\
\text { percentage } \\
\text { of } \\
\text { oven-dried } \\
\text { mass }\end{array}$ & $\begin{array}{c}\text { Soil } \\
\text { pH } \\
\text { (standard } \\
\text { pH units) }\end{array}$ & $\begin{array}{c}\text { Total } \\
\text { carbon, } \\
\text { as } \\
\text { percentage } \\
\text { of } \\
\text { oven-dried } \\
\text { mass as } \\
\text { carbon }\end{array}$ & $\begin{array}{l}\text { Inorganic } \\
\text { carbon, } \\
\text { as } \\
\text { percentage } \\
\text { of } \\
\text { oven-dried } \\
\text { mass as } \\
\text { carbon }\end{array}$ & $\begin{array}{l}\text { Total } \\
\text { nitrogen, } \\
\text { as } \\
\text { percentage } \\
\text { of } \\
\text { oven-dried } \\
\text { mass as } \\
\text { nitrogen }\end{array}$ & $\begin{array}{c}\text { Nitrite } \\
\text { plus } \\
\text { nitrate, } \\
\text { as } \\
\text { mg } \\
\text { nitrogen } \\
\text { per kg } \\
\text { of } \\
\text { oven-dried } \\
\text { mass }\end{array}$ & $\begin{array}{c}\text { Total } \\
\text { inorganic } \\
\text { phosphorus, } \\
\text { as } \\
\text { mg } \\
\text { phosphorus } \\
\text { per kg } \\
\text { of } \\
\text { oven-dried } \\
\text { mass }\end{array}$ & $\begin{array}{c}\text { Total } \\
\text { phosphorus, } \\
\text { as } \\
\text { mg } \\
\text { phosphorus } \\
\text { per kg } \\
\text { of } \\
\text { oven-dried } \\
\text { mass }\end{array}$ \\
\hline ALG-01A & 0.30 & 0.60 & 0.30 & - & D & SAPRIC PEAT & 85.8 & 58.8 & - & 31.5 & 68.5 & 89.5 & - & 4.5 & - & 0.27 & 14 & - & 540 \\
\hline ALG-01B & 0.70 & 0.90 & 0.20 & - & D & CLAY & - & - & - & - & - & - & - & - & - & - & - & - & - \\
\hline ALG-01C & 1.10 & 1.30 & 0.20 & - & D & CLAY & - & - & - & - & - & - & - & - & - & - & - & - & - \\
\hline ALG-01D & 2.00 & 2.30 & 0.30 & - & D & SAND & - & - & - & - & - & - & - & - & - & - & - & - & - \\
\hline ALG-01E & 4.00 & 4.30 & 0.30 & - & D & SAND & - & - & - & - & - & - & - & - & - & - & - & - & - \\
\hline ALG-02A & 0.00 & 0.70 & 0.70 & - & D & SAPRIC PEAT & 68.8 & 36.6 & - & 46.8 & 53.2 & 70.4 & - & 16.8 & - & 1.06 & 38 & - & 830 \\
\hline ALG-02B & 6.00 & 6.30 & 0.30 & 47.8 & $\mathrm{~L}$ & CLAY WITH SAND & - & - & - & - & - & - & - & - & - & - & - & - & 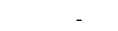 \\
\hline ALG-03A & 0.70 & 1.20 & 0.50 & - & $\mathrm{D}$ & SAPRIC PEAT & 74.9 & 34.9 & - & 53.4 & 46.6 & 80.1 & - & 10.9 & - & 0.91 & 46 & - & 560 \\
\hline ALG-03B & 5.50 & 5.80 & 0.30 & 20.6 & $\mathrm{~s}$ & PUMICE SAND & - & - & - & - & - & - & - & - & - & - & - & - & - \\
\hline ALG-03C & 9.40 & 9.70 & 0.30 & 47.8 & $\mathrm{~L}$ & CLAY WITH PUMICE SAND & - & - & - & - & - & - & - & - & - & - & - & - & - \\
\hline ALG-04A & 0.70 & 1.10 & 0.40 & - & D & SAPRIC PEAT & 69.8 & 41.2 & - & 40.9 & 59.1 & 65.9 & - & 19.5 & - & 1.00 & 24 & - & 1,260 \\
\hline ALG-05A & 0.70 & 1.10 & 0.40 & - & $\mathrm{D}$ & SAPRIC PEAT & 79.9 & 49.2 & - & 38.5 & 61.5 & 85.0 & - & 7.7 & - & 0.49 & 70 & - & 1,070 \\
\hline ALN-01A & 2.10 & 2.40 & 0.30 & 47.8 & $\mathrm{~L}$ & HEMIC PEAT & 49.6 & 8.8 & 0.1832 & 82.3 & 17.7 & 58.0 & - & 22.5 & - & 1.44 & 74 & - & 300 \\
\hline ALN-01B & 6.20 & 6.50 & 0.30 & 47.8 & $\mathrm{~L}$ & HEMIC PEAT & 49.1 & 6.0 & 0.1250 & 87.8 & 12.2 & 36.3 & - & 36.2 & - & 1.98 & 149 & - & 310 \\
\hline ALN-01C & 8.00 & 8.30 & 0.30 & 47.8 & $\mathrm{~L}$ & HEMIC PEAT & 45.9 & 8.9 & 0.1856 & 80.7 & 19.3 & 57.1 & - & 24.7 & - & 1.60 & 167 & - & 190 \\
\hline ALN-02A & 2.50 & 2.80 & 0.30 & 47.8 & $\mathrm{~L}$ & HEMIC PEAT & 54.5 & 8.9 & 0.1860 & 83.7 & 16.3 & 48.9 & - & 28.1 & - & 1.51 & 409 & - & 230 \\
\hline ALN-02B & 7.50 & 7.80 & 0.30 & 47.8 & $\mathrm{~L}$ & HEMIC PEAT & 51.1 & 9.3 & 0.1951 & 81.8 & 18.2 & 65.7 & - & 17.9 & - & 0.94 & 241 & - & 160 \\
\hline ALN-02C & 10.75 & 11.05 & 0.30 & 47.8 & $\mathrm{~L}$ & HEMIC PEAT & 49.3 & 7.1 & 0.1490 & 85.6 & 14.4 & 34.0 & - & 36.6 & - & 1.69 & 266 & - & 560 \\
\hline ALN-03A & 2.10 & 2.40 & 0.30 & 47.8 & $\mathrm{~L}$ & HEMIC PEAT & 51.0 & 12.3 & 0.2570 & 75.9 & 24.1 & 32.7 & - & 27.5 & - & 1.62 & 55 & - & 300 \\
\hline ALN-03B & 3.80 & 4.10 & 0.30 & 47.8 & $\mathrm{~L}$ & HEMIC PEAT & 54.5 & 6.8 & 0.1433 & 87.4 & 12.6 & 12.8 & - & 48.2 & - & 2.16 & 79 & - & 310 \\
\hline ALN-03C & 8.90 & 9.20 & 0.30 & 47.8 & $\mathrm{~L}$ & HEMIC PEAT & 49.9 & 6.3 & 0.1319 & 87.4 & 12.6 & 31.7 & - & 36.3 & - & 1.60 & 163 & - & 320 \\
\hline ALN-04A & 2.60 & 2.90 & 0.30 & 47.8 & $\mathrm{~L}$ & HEMIC PEAT & 49.2 & 10.2 & 0.2134 & 79.2 & 20.8 & 37.8 & 5.4 & 28.8 & $<0.01$ & 1.86 & 39 & - & - \\
\hline ALN-04B & 2.90 & 3.20 & 0.30 & 47.8 & $\mathrm{~L}$ & HEMIC PEAT & 45.9 & 10.7 & 0.2239 & 76.6 & 23.4 & - & 5.5 & 33.4 & - & 2.10 & 19 & - & 390 \\
\hline ALN-04C & 7.40 & 7.70 & 0.30 & 47.8 & $\mathrm{~L}$ & HEMIC/SAPRIC PEAT & 48.5 & 7.2 & 0.1509 & 85.1 & 14.9 & 45.5 & - & 28.7 & - & 1.38 & 171 & - & 450 \\
\hline ALN-04D & 10.80 & 11.10 & 0.30 & 47.8 & $\mathrm{~L}$ & HEMIC/SAPRIC PEAT & 49.4 & 8.0 & 0.1677 & 83.8 & 16.2 & 43.5 & - & 31.1 & - & 1.80 & 5 & - & 250 \\
\hline ALW-01A & 1.00 & 1.30 & 0.30 & 47.8 & $\mathrm{~L}$ & HEMIC PEAT & 49.6 & 8.8 & 0.1841 & 82.3 & 17.7 & - & 5.9 & 29.9 & - & 2.09 & - & 107.3 & - \\
\hline ALW-01B & 4.60 & 4.90 & 0.30 & 47.8 & $\mathrm{~L}$ & HEMIC PEAT & 46.6 & 6.4 & 0.1347 & 86.1 & 13.9 & 42.9 & - & 31.9 & - & 2.21 & 170 & - & 310 \\
\hline ALW-01C & 7.00 & 7.30 & 0.30 & 47.8 & $\mathrm{~L}$ & CLAY & - & - & - & - & - & - & - & - & - & - & - & - & - \\
\hline ALW-01D & 11.40 & 11.70 & 0.30 & 47.8 & $\mathrm{~L}$ & CLAY & - & - & - & - & - & - & - & - & - & - & - & - & - \\
\hline ALW-01E & 13.10 & 13.40 & 0.30 & 47.8 & $\mathrm{~L}$ & CLAY & - & - & - & - & - & - & - & - & - & - & - & - & - \\
\hline ALW-02A & 0.00 & 0.25 & 0.25 & - & D & SAPRIC PEAT & 56.7 & 23.1 & . & 59.3 & 40.7 & 53.6 & - & 23.8 & - & 1.71 & 123 & - & 850 \\
\hline ALW-02B & 4.30 & 4.60 & 0.30 & 47.8 & $\mathrm{~L}$ & HEMIC PEAT & 52.0 & 5.7 & 0.1193 & 89.0 & 11.0 & 19.1 & - & 46.6 & - & 2.43 & 178 & - & 290 \\
\hline ALW-02C & 9.50 & 9.80 & 0.30 & 47.8 & $\mathrm{~L}$ & CLAY & - & - & & - & - & - & - & - & - & - & - & - & - \\
\hline ALW-03A & 1.00 & 1.30 & 0.30 & 47.8 & $\mathrm{~L}$ & HEMIC PEAT & 49.7 & 10.8 & 0.2260 & 78.4 & 21.6 & 46.3 & 5.9 & 22.8 & $<0.01$ & 1.98 & 47 & - & 360 \\
\hline ALW-03B & 4.60 & 4.90 & 0.30 & 47.8 & $\mathrm{~L}$ & HEMIC PEAT & 49.7 & 6.1 & 0.1282 & 87.7 & 12.3 & 25.1 & - & 43.2 & - & 2.42 & 206 & - & 310 \\
\hline ALW-03C & 7.60 & 7.90 & 0.30 & 47.8 & $\mathrm{~L}$ & HEMIC PEAT & 25.4 & 3.8 & 0.0797 & 85.0 & 15.0 & 35.5 & - & 35.3 & - & 1.87 & 289 & - & 240 \\
\hline ALW-04A & 0.00 & 0.30 & 0.30 & & D & HEMIC PEAT & 24.6 & 13.2 & & 46.3 & 53.7 & 27.4 & & 38.3 & - & 2.63 & 250 & - & 910 \\
\hline ALW-04B & 1.20 & 1.50 & 0.30 & 47.8 & $\mathrm{~L}$ & HEMIC PEAT & 37.0 & 6.2 & 0.1297 & 83.2 & 16.8 & - & 5.6 & 24.5 & $<0.01$ & 2.82 & 84 & - & 630 \\
\hline
\end{tabular}




\begin{tabular}{|c|c|c|c|c|c|c|c|c|c|c|c|c|c|c|c|c|c|c|c|}
\hline $\begin{array}{c}\text { Sample } \\
\text { name }\end{array}$ & $\begin{array}{r}\text { Sa } \\
\text { de } \\
\text { Top }\end{array}$ & $\begin{array}{l}\text { iple } \\
\text { th } \\
\text { : Bottom }\end{array}$ & $\begin{array}{l}\text { Length } \\
\text { of sample } \\
\text { interval } \\
\text { (ft) }\end{array}$ & $\begin{array}{c}\text { Volume } \\
(\mathrm{mL})\end{array}$ & $\begin{array}{l}\text { Sample } \\
\text { method }\end{array}$ & Soil material & $\begin{array}{l}\text { Sample } \\
\text { weight } \\
\text { as } \\
\text { received } \\
\text { (g) }\end{array}$ & $\begin{array}{l}\text { Sample } \\
\text { weight } \\
\text { dry } \\
\text { (g) }\end{array}$ & $\begin{array}{c}\text { Bulk } \\
\text { density } \\
\text { (g per } \\
\text { cubic cm) }\end{array}$ & $\begin{array}{c}\text { Percent } \\
\text { moisture, } \\
\text { as } \\
\text { percentage } \\
\text { of } \\
\text { total mass }\end{array}$ & $\begin{array}{c}\text { Percent } \\
\text { dry matter, } \\
\text { as } \\
\text { percentage } \\
\text { of } \\
\text { total mass }\end{array}$ & $\begin{array}{l}\text { Percent } \\
\text { ash } \\
\text { content, } \\
\text { as } \\
\text { percentage } \\
\text { of } \\
\text { oven-dried } \\
\text { mass }\end{array}$ & $\begin{array}{c}\text { Soil } \\
\text { pH } \\
\text { (standard } \\
\text { pH units) }\end{array}$ & $\begin{array}{c}\text { Total } \\
\text { carbon, } \\
\text { as } \\
\text { percentage } \\
\text { of } \\
\text { oven-dried } \\
\text { mass as } \\
\text { carbon }\end{array}$ & $\begin{array}{l}\text { Inorganic } \\
\text { carbon, } \\
\text { as } \\
\text { percentage } \\
\text { of } \\
\text { oven-dried } \\
\text { mass as } \\
\text { carbon }\end{array}$ & $\begin{array}{l}\text { Total } \\
\text { nitrogen, } \\
\text { as } \\
\text { percentage } \\
\text { of } \\
\text { oven-dried } \\
\text { mass as } \\
\text { nitrogen }\end{array}$ & $\begin{array}{c}\text { Nitrite } \\
\text { plus } \\
\text { nitrate, } \\
\text { as } \\
\text { mg } \\
\text { nitrogen } \\
\text { per kg } \\
\text { of } \\
\text { oven-dried } \\
\text { mass }\end{array}$ & $\begin{array}{c}\text { Total } \\
\text { inorganic } \\
\text { phosphorus, } \\
\text { as } \\
\text { mg } \\
\text { phosphorus } \\
\text { per kg } \\
\text { of } \\
\text { oven-dried } \\
\text { mass }\end{array}$ & $\begin{array}{c}\text { Total } \\
\text { phosphorus, } \\
\text { as } \\
\mathrm{mg} \\
\text { phosphorus } \\
\text { per kg } \\
\text { of } \\
\text { oven-dried } \\
\text { mass }\end{array}$ \\
\hline ALW-04C & 4.50 & 4.80 & 0.30 & 47.8 & L & HEMIC PEAT & 51.4 & 6.6 & 0.1381 & 87.2 & 12.8 & 34.3 & 5.8 & 3.6 & $<0.01$ & 2.53 & 81 & - & 270 \\
\hline ALW-04D & 7.50 & 7.80 & 0.30 & 47.8 & $\mathrm{~L}$ & HEMIC PEAT & 51.9 & 7.3 & 0.1527 & 85.9 & 14.1 & 41.5 & 5.7 & 2.1 & $<0.01$ & 1.83 & 101 & - & 250 \\
\hline ALW-04E & 7.80 & 8.10 & 0.30 & 47.8 & $\mathrm{~L}$ & HEMIC PEAT & 50.5 & 7.0 & 0.1465 & 86.2 & 13.8 & 46.5 & 5.7 & 2.7 & $<0.01$ & 1.62 & 90 & - & 200 \\
\hline BBS-01A & 0.40 & 0.70 & 0.30 & - & D & SAPRIC PEAT WITH MINERA & AL SOIL60.6 & 30.3 & - & 50.0 & 50.0 & 85.3 & - & 5.6 & - & 0.71 & 27 & - & 320 \\
\hline BBS-01B & 0.80 & 1.10 & 0.30 & - & D & SAPRIC PEAT WITH CLAY & 67.2 & 38.8 & - & 42.2 & 57.8 & 86.4 & - & 3.8 & - & 0.50 & 23 & - & 310 \\
\hline BBS-01C & 2.00 & 2.40 & 0.40 & - & D & CLAY & - & - & - & - & - & - & - & - & - & - & - & - & - \\
\hline BBS-01D & 3.60 & 4.00 & 0.40 & - & D & CLAY WITH SAND & - & - & - & - & - & - & - & - & - & - & - & - & - \\
\hline BBS-02A & 2.80 & 3.10 & 0.30 & 47.8 & $\mathrm{~L}$ & CLAY WITH PEBBLES & - & - & - & - & - & - & - & - & - & - & - & - & - \\
\hline BBW-01A & 0.40 & 1.30 & 0.90 & - & $\mathrm{D}$ & SAPRIC PEAT WITH CLAY & 96.2 & 38.8 & - & 59.7 & 40.3 & 63.0 & - & 17.70 & - & 1.50 & 46 & - & 820 \\
\hline BBW-01B & 1.50 & 1.80 & 0.30 & 47.8 & $\mathrm{~L}$ & SAPRIC PEAT WITH CLAY & 55.4 & 21.4 & 0.4482 & 61.3 & 38.7 & 80.6 & - & 8.08 & - & 0.64 & 8 & - & 310 \\
\hline BBW-01C & 2.90 & 3.20 & 0.30 & 47.8 & $\mathrm{~L}$ & CLAY & 53.6 & 15.0 & 0.3139 & 72.1 & 27.9 & 88.4 & 7.3 & 3.9 & 0.01 & 0.30 & 12 & - & 160 \\
\hline BBW-02A & 0.60 & 0.90 & 0.30 & 47.8 & $\mathrm{~L}$ & HEMIC/SAPRIC PEAT & 34.2 & 7.7 & 0.1611 & 77.5 & 22.5 & 43.6 & 5.8 & 23.7 & $<0.01$ & 2.11 & 88 & - & 770 \\
\hline BBW-02B & 2.10 & 2.40 & 0.30 & 47.8 & $\mathrm{~L}$ & HEMIC/SAPRIC PEAT & 49.9 & 8.2 & 0.1705 & 83.7 & 16.3 & 20.3 & - & 44.00 & - & 2.90 & 39 & - & 540 \\
\hline BBW-02C & 2.90 & 3.20 & 0.30 & 47.8 & $\mathrm{~L}$ & SAPRIC PEAT WITH CLAY & 51.3 & 13.2 & 0.2767 & 74.2 & 25.8 & 69.0 & - & 17.10 & - & 1.37 & 25 & - & 470 \\
\hline BBW-02D & 8.00 & 8.30 & 0.30 & 47.8 & $\mathrm{~L}$ & CLAY & - & - & - & - & - & - & - & - & - & - & - & - & - \\
\hline BBW-02E & 9.70 & 10.00 & 0.30 & 47.8 & $\mathrm{~L}$ & HEMIC/SAPRIC PEAT & 51.0 & 7.1 & 0.1496 & 86.0 & 14.0 & 25.0 & - & 42.90 & - & 2.02 & 4 & - & 470 \\
\hline BBW-02F & 11.00 & 11.30 & 0.30 & 47.8 & $\mathrm{~L}$ & HEMIC PEAT WITH CLAY & 54.7 & 9.3 & 0.1938 & 83.1 & 16.9 & 69.4 & - & 16.80 & - & 1.46 & 17 & - & 320 \\
\hline CAM- $01 \mathrm{~A}$ & 0.70 & 1.30 & 0.60 & - & $\mathrm{D}$ & SAPRIC PEAT & 83.0 & 38.5 & - & 53.6 & 46.4 & 64.7 & - & 16.2 & - & 1.03 & 136 & - & 430 \\
\hline CAM- $01 \mathrm{~B}$ & 2.70 & 3.00 & 0.30 & 47.8 & $\mathrm{~L}$ & SAPRIC PEAT & 39.8 & 10.1 & 0.2118 & 74.6 & 25.4 & 30.0 & - & 38.6 & - & 1.96 & 47 & - & 280 \\
\hline CAM- $01 \mathrm{C}$ & 4.20 & 4.50 & 0.30 & 47.8 & $\mathrm{~L}$ & HEMIC PEAT & 24.5 & 3.8 & 0.0787 & 84.7 & 15.3 & 9.2 & - & 52.5 & - & 2.06 & 23 & - & 300 \\
\hline CAM-01D & 8.00 & 8.30 & 0.30 & 47.8 & $\mathrm{~L}$ & HEMIC PEAT & 48.7 & 6.6 & 0.1375 & 86.5 & 13.5 & 25.0 & - & 42.7 & - & 2.19 & 124 & - & 320 \\
\hline CAM-01E & 9.30 & 9.60 & 0.30 & 47.8 & $\mathrm{~L}$ & CLAY WITH HEMIC PEAT & 53.3 & 12.3 & 0.2575 & 76.9 & 23.1 & 77.9 & - & 10.4 & - & 0.87 & 209 & - & 220 \\
\hline CAM- $01 \mathrm{~F}$ & 9.60 & 9.90 & 0.30 & 47.8 & $\mathrm{~L}$ & CLAY WITH HEMIC PEAT & 25.5 & 5.4 & 0.1135 & 78.7 & 21.3 & 76.7 & - & 11.1 & - & 1.00 & 200 & - & 210 \\
\hline CAM-02A & 1.70 & 2.00 & 0.30 & - & D & SAPRIC PEAT WITH ASH? & 51.6 & 2.2 & - & 95.7 & 4.3 & 82.4 & 6.0 & 5.7 & $<0.01$ & 0.56 & 33 & - & 340 \\
\hline CAM-02B & 2.90 & 3.20 & 0.30 & - & $\mathrm{D}$ & $\begin{array}{l}\text { SAPRIC PEAT } \\
\text { S }\end{array}$ & 81.1 & 30.7 & - & 62.2 & 37.8 & 88.1 & 6.1 & 4.0 & $<0.01$ & 0.29 & 25 & 119.1 & 120 \\
\hline CAM- $02 \mathrm{C}$ & 4.10 & 4.40 & 0.30 & 20.6 & $\mathrm{~s}$ & SAPRIC PEAT & 17.0 & 6.4 & 0.3108 & 62.6 & 37.4 & 86.1 & 6.0 & 3.4 & $<0.01$ & 0.37 & 25 & - & 140 \\
\hline CAM-02D & 4.40 & 4.70 & 0.30 & 20.6 & $\mathrm{~s}$ & SAPRIC PEAT & 18.0 & 6.7 & 0.3254 & 62.9 & 37.1 & - & 6.0 & 4.2 & - & 0.30 & 18 & - & 160 \\
\hline CAM-02E & 6.30 & 6.70 & 0.40 & 27.5 & $\mathrm{~s}$ & SAPRIC PEAT WITH CLAY & 25.1 & 9.4 & 0.3424 & 62.5 & 37.5 & 82.2 & 5.4 & 6.3 & $<0.01$ & 0.40 & 28 & - & 240 \\
\hline CAM- $02 \mathrm{~F}$ & 7.50 & 7.80 & 0.30 & 20.6 & $\mathrm{~s}$ & HEMIC PEAT WITH CLAY & 17.1 & 3.6 & 0.1748 & 78.8 & 21.2 & - & 3.2 & 14.5 & - & 1.05 & 22 & - & - \\
\hline CAM-03A & 0.80 & 1.70 & 0.90 & - & $\mathrm{D}$ & SAPRIC PEAT & 21.4 & 10.3 & - & 52.1 & 47.9 & 33.3 & - & 36.5 & - & 1.74 & 53 & - & 480 \\
\hline CAM- $03 \mathrm{~B}$ & 2.80 & 3.20 & 0.40 & - & $\mathrm{D}$ & HEMIC PEAT & 28.6 & 6.9 & - & 75.8 & 24.2 & 21.5 & - & 42.0 & - & 3.00 & 36 & - & 470 \\
\hline CAM- $03 \mathrm{C}$ & 4.10 & 4.40 & 0.30 & 47.8 & $\mathrm{~L}$ & HEMIC PEAT WITH CLAY & 26.2 & 5.3 & 0.1108 & 79.8 & 20.2 & 75.5 & - & 11.8 & - & 1.07 & 29 & - & 150 \\
\hline CAM-03D & 6.40 & 6.70 & 0.30 & 47.8 & $\mathrm{~L}$ & CLAY & - & - & - & - & - & - & - & - & - & - & - & - & - \\
\hline CAM-04A & 0.00 & 0.70 & 0.70 & - & $\mathrm{D}$ & SAPRIC PEAT & 87.1 & 53.3 & - & 38.8 & 61.2 & 63.5 & 7.6 & 16.7 & 0.02 & 1.06 & 66 & - & 870 \\
\hline CAM-04B & 1.50 & 1.80 & 0.30 & 20.6 & $\mathrm{~s}$ & CLAY WITH HEMIC PEAT & 17.7 & 6.5 & 0.3156 & 63.5 & 36.5 & 80.2 & 7.4 & 7.5 & $<0.01$ & 0.53 & 54 & - & 320 \\
\hline CAM- $04 \mathrm{C}$ & 1.80 & 2.10 & 0.30 & 20.6 & $\mathrm{~s}$ & CLAY WITH HEMIC PEAT & 16.8 & 5.3 & 0.2574 & 68.1 & 31.9 & - & 6.7 & 5.4 & $<0.01$ & 0.43 & 14 & - & 210 \\
\hline CAM-04D & 2.90 & 3.00 & 0.10 & - & $\mathrm{D}$ & CLAY WITH SAND & 83.5 & 58.0 & - & 30.5 & 69.5 & 93.7 & 5.2 & 0.9 & $<0.01$ & 0.06 & 7 & - & 270 \\
\hline CAM-05A & 0.40 & 0.70 & 0.30 & 47.8 & $\mathrm{~L}$ & SAPRIC PEAT & 51.2 & 22.8 & 0.4760 & 55.6 & 44.4 & 61.7 & - & 19.3 & - & 1.11 & 54 & - & 910 \\
\hline CAM-05B & 0.70 & 1.00 & 0.30 & 47.8 & $\mathrm{~L}$ & SAPRIC PEAT & 52.5 & 20.8 & 0.4352 & 60.4 & 39.6 & 56.1 & 7.5 & 20.3 & 0.03 & 1.13 & 54 & - & 730 \\
\hline CAM-06A & 0.20 & 1.20 & 1.00 & - & D & SAPRIC PEAT & 73.4 & 42.4 & - & 42.2 & 57.8 & 66.0 & - & 16.7 & - & 1.32 & 41 & - & 690 \\
\hline CAM-06B & 3.70 & 4.00 & 0.30 & 47.8 & $\mathrm{~L}$ & SAPRIC PEAT WITH CLAY & 37.2 & 8.6 & 0.1799 & 76.8 & 23.2 & 52.9 & 5.3 & 21.8 & $<0.01$ & 1.47 & 128 & - & 580 \\
\hline CAM-06C & 4.00 & 4.30 & 0.30 & 47.8 & $\mathrm{~L}$ & HEMIC/SAPRIC PEAT & 45.4 & 8.6 & 0.1795 & 81.1 & 18.9 & 43.4 & - & 30.6 & - & 1.77 & 59 & - & 500 \\
\hline CAM-06D & 5.80 & 6.10 & 0.30 & 47.8 & $\mathrm{~L}$ & HEMIC PEAT & 49.5 & 7.3 & 0.1527 & 85.3 & 14.7 & 22.8 & - & 42.7 & - & 2.34 & 132 & - & 490 \\
\hline CAM-07A & 0.70 & 1.20 & 0.50 & - & $\mathrm{D}$ & SAPRIC PEAT & 83.8 & 38.6 & - & 54.0 & 46.0 & 45.8 & - & 28.7 & - & 1.87 & 98 & - & 560 \\
\hline CAM-07B & 2.30 & 2.60 & 0.30 & 47.8 & $\mathrm{~L}$ & HEMIC/SAPRIC PEAT & 44.3 & 10.3 & 0.2147 & 76.8 & 23.2 & 26.7 & - & 40.3 & - & 2.44 & 51 & - & 330 \\
\hline CAM-07C & 4.10 & 4.40 & 0.30 & 47.8 & $\mathrm{~L}$ & CLAY WITH HEMIC PEAT & 46.6 & 9.4 & 0.1957 & 79.9 & 20.1 & 63.1 & - & 18.3 & - & 1.45 & 71 & - & 240 \\
\hline CAM-07D & 6.20 & 6.50 & 0.30 & 47.8 & $\mathrm{~L}$ & CLAY WITH SAND & - & - & - & - & - & - & - & - & - & - & - & - & - \\
\hline CAM-08A & 0.40 & 0.70 & 0.30 & 47.8 & $\mathrm{~L}$ & SAPRIC PEAT & 45.0 & 13.6 & 0.2846 & 69.7 & 30.3 & 39.7 & 6.0 & 25.4 & 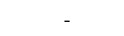 & 2.43 & - & - & - \\
\hline CAM-08B & 0.70 & 1.00 & 0.30 & 47.8 & $\mathrm{~L}$ & SAPRIC PEAT & 45.8 & 11.6 & 0.2427 & 74.7 & 25.3 & 37.6 & 5.6 & 29.0 & $<0.01$ & 2.66 & 109 & - & 1,510 \\
\hline
\end{tabular}




\begin{tabular}{|c|c|c|c|c|c|c|c|c|c|c|c|c|c|c|c|c|c|c|c|}
\hline $\begin{array}{l}\text { Sample } \\
\text { name }\end{array}$ & $\begin{array}{r}\text { Sal } \\
\text { de } \\
\text { Top }\end{array}$ & $\begin{array}{l}\text { nple } \\
\text { pth } \\
\text { t) } \\
\text { Bottom }\end{array}$ & $\begin{array}{l}\text { Length } \\
\text { of sample } \\
\text { interval } \\
\text { (ft) }\end{array}$ & Volume & $\begin{array}{l}\text { Sample } \\
\text { method }\end{array}$ & Soil material & $\begin{array}{c}\text { Sample } \\
\text { weight } \\
\text { as } \\
\text { received } \\
\text { (g) }\end{array}$ & $\begin{array}{l}\text { Sample } \\
\text { weight } \\
\text { dry } \\
\text { (g) }\end{array}$ & $\begin{array}{c}\text { Bulk } \\
\text { density } \\
\text { (g per } \\
\text { cubic } \mathrm{cm} \text { ) }\end{array}$ & $\begin{array}{c}\text { Percent } \\
\text { moisture, } \\
\text { as } \\
\text { percentage } \\
\text { of } \\
\text { total mass }\end{array}$ & $\begin{array}{c}\text { Percent } \\
\text { dry matter, } \\
\text { as } \\
\text { percentage } \\
\text { of } \\
\text { total mass }\end{array}$ & $\begin{array}{l}\text { Percent } \\
\text { ash } \\
\text { content, } \\
\text { as } \\
\text { percentage } \\
\text { of } \\
\text { oven-dried } \\
\text { mass }\end{array}$ & $\begin{array}{c}\text { Soil } \\
\text { pH } \\
\text { (standard } \\
\text { pH units) }\end{array}$ & $\begin{array}{c}\text { Total } \\
\text { carbon, } \\
\text { as } \\
\text { percentage } \\
\text { of } \\
\text { oven-dried } \\
\text { mass as } \\
\text { carbon }\end{array}$ & $\begin{array}{l}\text { Inorganic } \\
\text { carbon, } \\
\text { as } \\
\text { percentage } \\
\text { of } \\
\text { oven-dried } \\
\text { mass as } \\
\text { carbon }\end{array}$ & $\begin{array}{l}\text { Total } \\
\text { nitrogen, } \\
\text { as } \\
\text { percentage } \\
\text { of } \\
\text { oven-dried } \\
\text { mass as } \\
\text { nitrogen }\end{array}$ & $\begin{array}{c}\text { Nitrite } \\
\text { plus } \\
\text { nitrate, } \\
\text { as } \\
\text { mg } \\
\text { nitrogen } \\
\text { per kg } \\
\text { of } \\
\text { oven-dried } \\
\text { mass }\end{array}$ & $\begin{array}{c}\text { Total } \\
\text { inorganic } \\
\text { phosphorus, } \\
\text { as } \\
\text { mg } \\
\text { phosphorus } \\
\text { per kg } \\
\text { of } \\
\text { oven-dried } \\
\text { mass }\end{array}$ & $\begin{array}{c}\text { Total } \\
\text { phosphorus } \\
\text { as } \\
\text { mg } \\
\text { phosphorus } \\
\text { per kg } \\
\text { of } \\
\text { oven-dried } \\
\text { mass }\end{array}$ \\
\hline CAM-08C & 2.60 & 2.90 & 0.30 & 47.8 & $\mathrm{~L}$ & CLAY & 49.9 & 6.6 & 0.1381 & 86.8 & 13.2 & 65.8 & 5.0 & 13.4 & $<0.01$ & 1.28 & 72 & - & 490 \\
\hline CAM-08D & 8.00 & 8.30 & 0.30 & 47.8 & $\mathrm{~L}$ & HEMIC PEAT & 43.1 & 4.5 & 0.0951 & 89.5 & 10.5 & 31.5 & - & 38.3 & - & 2.02 & 243 & - & 350 \\
\hline CAM-08E & 11.40 & 11.70 & 0.30 & 47.8 & $\mathrm{~L}$ & CLAY WITH HEMIC PEAT & 47.6 & 7.1 & 0.1486 & 85.0 & 15.0 & 76.3 & 5.2 & 8.4 & $<0.01$ & 0.96 & 106 & - & 200 \\
\hline CAM-08F & 17.80 & 18.10 & 0.30 & 47.8 & $\mathrm{~L}$ & CLAY & - & - & - & - & - & - & - & - & - & - & - & - & - \\
\hline CAM-08G & 18.10 & 18.40 & 0.30 & 47.8 & $\mathrm{~L}$ & CLAY & 65.0 & 32.2 & 0.6733 & 50.5 & 49.5 & 95.1 & - & 0.5 & - & 0.14 & 8 & - & 770 \\
\hline COV-01A & 0.90 & 1.40 & 0.50 & - & D & SAPRIC PEAT & 41.8 & 17.4 & - & 58.3 & 41.7 & 72.3 & - & 13.5 & - & 1.02 & 34 & - & 410 \\
\hline COV-01B & 2.20 & 2.50 & 0.30 & - & D & SAPRIC PEAT WITH CLAY & 77.7 & 34.6 & - & 55.4 & 44.6 & 87.1 & - & 6.0 & - & 0.45 & 13 & - & 140 \\
\hline COV-01C & 3.10 & 3.40 & 0.30 & - & D & SAPRIC PEAT & 85.5 & 36.9 & - & 56.8 & 43.2 & 96.3 & - & 6.0 & - & 0.36 & 6 & - & 90 \\
\hline COV-01D & 4.10 & 4.20 & 0.10 & - & D & PUMICE SAND & 30.2 & 22.0 & - & 27.4 & 72.6 & 94.5 & - & 1.7 & - & 0.09 & 3 & - & 330 \\
\hline COV-01E & 5.00 & 5.40 & 0.40 & - & D & CLAY & - & - & - & - & - & - & - & - & - & - & - & - & - \\
\hline COV-01F & 5.40 & 6.00 & 0.60 & 41.2 & $\mathrm{~s}$ & CLAY & - & - & - & - & - & - & - & - & - & - & - & - & - \\
\hline COV-02A & 0.70 & 1.20 & 0.50 & - & D & SAPRIC PEAT & 75.1 & 42.9 & - & 42.8 & 57.2 & 57.7 & - & 23.7 & - & 1.57 & 51 & - & 870 \\
\hline COV-02B & 2.80 & 3.10 & 0.30 & - & D & HEMIC PEAT WITH CLAY & 41.5 & 8.6 & - & 79.3 & 20.7 & 38.4 & - & 35.0 & - & 2.17 & 104 & - & 390 \\
\hline HNK-01A & 2.30 & 2.60 & 0.30 & 47.8 & $\mathrm{~L}$ & HEMIC PEAT & 51.0 & 7.5 & 0.1569 & 85.3 & 14.7 & 34.0 & - & 38.4 & - & 3.04 & 18 & - & 480 \\
\hline HNK-01B & 2.60 & 2.90 & 0.30 & 47.8 & $\mathrm{~L}$ & HEMIC PEAT & 45.9 & 5.0 & 0.1046 & 89.0 & 11.0 & 14.8 & 6.2 & 38.2 & - & 3.78 & - & - & - \\
\hline HNK-01C & 4.60 & 4.90 & 0.30 & 47.8 & $\mathrm{~L}$ & SAPRIC PEAT & 47.6 & 7.0 & 0.1472 & 85.2 & 14.8 & 23.9 & - & 46.4 & - & 2.40 & 22 & - & 340 \\
\hline HNK-01D & 6.20 & 6.50 & 0.30 & 47.8 & $\mathrm{~L}$ & MUCK WITH SAPRIC PEAT & 48.2 & 8.5 & 0.1779 & 82.4 & 17.6 & 71.7 & 6.5 & 12.7 & $<0.01$ & 0.86 & 17 & 164.0 & - \\
\hline HNK-01E & 7.90 & 8.20 & 0.30 & 47.8 & $\mathrm{~L}$ & HEMIC PEAT & 49.3 & 9.5 & 0.1981 & 80.8 & 19.2 & 72.5 & - & 15.2 & - & 1.34 & 7 & - & 190 \\
\hline HNK-01F & 9.50 & 9.80 & 0.30 & 47.8 & $\mathrm{~L}$ & CLAY WITH HEMIC PEAT & 52.7 & 11.0 & 0.2295 & 79.2 & 20.8 & 83.5 & - & 8.0 & - & 0.81 & 13 & - & 190 \\
\hline HNK-01G & 12.90 & 13.20 & 0.30 & 47.8 & $\mathrm{~L}$ & CLAY WITH SAND & - & - & - & - & - & - & - & - & - & - & - & - & - \\
\hline HNK-01H & 17.70 & 18.00 & 0.30 & 47.8 & $\mathrm{~L}$ & CLAY & - & - & 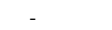 & - & - & - & - & - & - & - & - & - & - \\
\hline HNK-02A & 2.60 & 2.90 & 0.30 & 47.8 & $\mathrm{~L}$ & HEMIC PEAT & 46.7 & 8.2 & 0.1722 & 82.4 & 17.6 & 51.9 & - & 28.0 & - & 2.17 & 26 & - & 530 \\
\hline HNK-02B & 2.90 & 3.20 & 0.30 & 47.8 & $\mathrm{~L}$ & HEMIC PEAT & 44.4 & 5.9 & 0.1235 & 86.7 & 13.3 & - & 6.1 & 33.1 & - & 2.72 & - & - & 350 \\
\hline HNK-02C & 4.60 & 4.90 & 0.30 & 47.8 & $\mathrm{~L}$ & SAPRIC PEAT & 46.3 & 8.4 & 0.1767 & 81.8 & 18.2 & 47.3 & - & 30.4 & - & 1.81 & 29 & - & 330 \\
\hline HNK-02D & 7.40 & 7.70 & 0.30 & 47.8 & $\mathrm{~L}$ & SAPRIC PEAT & 48.5 & 8.3 & 0.1731 & 82.9 & 17.1 & 52.6 & - & 27.6 & - & 1.87 & 46 & - & 340 \\
\hline HNK-02E & 8.00 & 8.30 & 0.30 & 47.8 & $\mathrm{~L}$ & HEMIC PEAT & 44.8 & 5.4 & 0.1134 & 87.9 & 12.1 & 20.3 & - & 48.3 & - & 2.13 & 27 & - & 390 \\
\hline HNK-02F & 9.20 & 9.50 & 0.30 & 47.8 & $\mathrm{~L}$ & HEMIC PEAT WITH CLAY & 49.7 & 8.9 & 0.1870 & 82.0 & 18.0 & 76.9 & - & 12.0 & - & 1.07 & 49 & - & 240 \\
\hline HNK-02G & 10.60 & 10.90 & 0.30 & 47.8 & $\mathrm{~L}$ & CLAY WITH HEMIC PEAT & 51.6 & 13.9 & 0.2908 & 73.1 & 26.9 & 84.8 & 5.3 & 5.0 & $<0.01$ & 0.63 & 22 & - & 370 \\
\hline HNK-02H & 11.40 & 11.70 & 0.30 & 47.8 & $\mathrm{~L}$ & CLAY & - & - & - & - & - & - & - & - & - & - & - & - & - \\
\hline HNK-03A & 2.30 & 2.60 & 0.30 & 47.8 & $\mathrm{~L}$ & HEMIC/SAPRIC PEAT & 50.0 & 7.7 & 0.1618 & 84.5 & 15.5 & 41.8 & - & 32.6 & - & 2.15 & 25 & - & 500 \\
\hline HNK-03B & 2.90 & 3.20 & 0.30 & 47.8 & $\mathrm{~L}$ & HEMIC/SAPRIC PEAT & 22.0 & 3.2 & 0.0665 & 85.6 & 14.4 & 25.7 & - & 41.9 & - & 2.82 & 34 & - & 490 \\
\hline HNK-03C & 6.10 & 6.40 & 0.30 & 47.8 & $\mathrm{~L}$ & HEMIC PEAT & 42.8 & 6.6 & 0.1387 & 84.5 & 15.5 & 29.2 & - & 41.9 & - & 2.26 & 76 & - & 350 \\
\hline HNK-03D & 7.70 & 8.00 & 0.30 & 47.8 & $\mathrm{~L}$ & SAPRIC PEAT WITH CLAY & 52.4 & 14.2 & 0.2980 & 72.8 & 27.2 & 64.3 & - & 21.5 & - & 1.29 & 79 & - & 1,570 \\
\hline MCC-01A & 0.80 & 1.20 & 0.40 & - & D & MINERAL SOIL & 85.9 & 52.7 & - & 38.7 & 61.3 & 89.7 & 6.4 & 2.6 & $<0.01$ & 0.25 & 13 & - & 200 \\
\hline MCC-01B & 1.30 & 1.40 & 0.10 & - & D & MINERAL SOIL & 56.2 & 32.2 & - & 42.7 & 57.3 & 93.2 & - & 1.7 & - & 0.14 & 15 & - & 170 \\
\hline MCC-01C & 1.40 & 1.70 & 0.30 & - & D & CLAY & - & - & - & - & - & - & - & - & - & - & - & - & - \\
\hline MCC-01D & 2.90 & 3.20 & 0.30 & - & D & SAND WITH CLAY & - & - & - & - & - & - & - & - & - & - & - & - & - \\
\hline MCC-02A & 0.00 & 0.70 & 0.70 & - & D & SAPRIC PEAT & 114.5 & 71.8 & - & 37.3 & 62.7 & 90.7 & - & 3.0 & - & 0.27 & 12 & - & 380 \\
\hline MCC-03A & 0.00 & 0.70 & 0.70 & - & D & SAPRIC PEAT & 82.0 & 54.8 & - & 33.1 & 66.9 & 89.1 & - & 4.6 & - & 0.37 & 12 & - & 400 \\
\hline MCC-03B & 1.30 & 1.70 & 0.40 & - & D & ASH? CLAY WITH SAND & - & - & - & - & - & - & - & - & - & - & - & - & - \\
\hline NWR-01A & 0.50 & 0.80 & 0.30 & 47.8 & $\mathrm{~L}$ & MUCK WITH CLAY & 35.4 & 4.5 & 0.0948 & 87.2 & 12.8 & 51.5 & - & 26.8 & - & 2.45 & 10 & - & 760 \\
\hline NWR-01B & 2.50 & 2.80 & 0.30 & 47.8 & $\mathrm{~L}$ & HEMIC PEAT & 45.4 & 3.6 & 0.0753 & 92.1 & 7.9 & 19.3 & 4.2 & 38.1 & - & 2.90 & - & - & - \\
\hline NWR-01C & 2.80 & 3.10 & 0.30 & 47.8 & $\mathrm{~L}$ & HEMIC PEAT & 42.4 & 3.0 & 0.0628 & 92.9 & 7.1 & 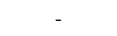 & 5.6 & 34.6 & - & 2.91 & - & - & - \\
\hline NWR-01D & 4.60 & 4.90 & 0.30 & 47.8 & $\mathrm{~L}$ & HEMIC PEAT & 47.3 & 3.7 & 0.0783 & 92.1 & 7.9 & 13.2 & - & 50.3 & - & 3.14 & 117 & - & 510 \\
\hline NWR-01E & 6.00 & 6.30 & 0.30 & 47.8 & $\mathrm{~L}$ & HEMIC PEAT & 47.1 & 4.8 & 0.1010 & 89.7 & 10.3 & 25.0 & - & 41.9 & - & 2.74 & 167 & - & 370 \\
\hline NWR-01F & 7.70 & 8.00 & 0.30 & 47.8 & $\mathrm{~L}$ & HEMIC PEAT & 48.5 & 5.2 & 0.1082 & 89.3 & 10.7 & 27.9 & - & 41.3 & - & 2.73 & 249 & - & 370 \\
\hline NWR-01G & 10.90 & 11.20 & 0.30 & 47.8 & $\mathrm{~L}$ & CLAY & 47.1 & 10.0 & 0.2092 & 78.8 & 21.2 & 82.6 & 5.4 & 6.2 & $<0.01$ & 0.67 & 14 & - & 110 \\
\hline NWR-01H & 11.20 & 11.50 & 0.30 & 47.8 & $\mathrm{~L}$ & CLAY & 49.3 & 10.0 & 0.2092 & 79.8 & 20.2 & 82.8 & 5.6 & 4.7 & $<0.01$ & 0.67 & 28 & 50.0 & 120 \\
\hline NWR-01I & 12.90 & 13.20 & 0.30 & 47.8 & $\mathrm{~L}$ & HEMIC PEAT & 46.9 & 5.0 & 0.1055 & 89.2 & 10.8 & 33.0 & & 37.7 & - & 2.20 & 289 & & 280 \\
\hline
\end{tabular}




\begin{tabular}{|c|c|c|c|c|c|c|c|c|c|c|c|c|c|c|c|c|c|c|c|}
\hline $\begin{array}{l}\text { Sample } \\
\text { name }\end{array}$ & $\begin{array}{r}\text { Sa } \\
d e \\
\text { Top }\end{array}$ & $\begin{array}{l}\text { nple } \\
\text { pth } \\
\text { t) } \\
\text { Bottom }\end{array}$ & $\begin{array}{l}\text { Length } \\
\text { of sample } \\
\text { interval } \\
\text { (ft) }\end{array}$ & $\begin{array}{l}\text { Volume } \\
(\mathrm{mL})\end{array}$ & $\begin{array}{l}\text { Sample } \\
\text { method }\end{array}$ & Soil material & $\begin{array}{l}\text { Sample } \\
\text { weight } \\
\text { as } \\
\text { received } \\
\text { (g) }\end{array}$ & $\begin{array}{c}\text { Sample } \\
\text { weight } \\
\text { dry } \\
\text { (g) }\end{array}$ & $\begin{array}{c}\text { Bulk } \\
\text { density } \\
\text { (g per } \\
\text { cubic cm) }\end{array}$ & $\begin{array}{c}\text { Percent } \\
\text { moisture, } \\
\text { as } \\
\text { percentage } \\
\text { of } \\
\text { total mass }\end{array}$ & $\begin{array}{c}\text { Percent } \\
\text { dry matter, } \\
\text { as } \\
\text { percentage } \\
\text { of } \\
\text { total mass }\end{array}$ & $\begin{array}{l}\text { Percent } \\
\text { ash } \\
\text { content, } \\
\text { as } \\
\text { percentage } \\
\text { of } \\
\text { oven-dried } \\
\text { mass }\end{array}$ & $\begin{array}{c}\text { Soil } \\
\text { pH } \\
\text { (standard } \\
\text { pH units) }\end{array}$ & $\begin{array}{c}\text { Total } \\
\text { carbon, } \\
\text { as } \\
\text { percentage } \\
\text { of } \\
\text { oven-dried } \\
\text { mass as } \\
\text { carbon }\end{array}$ & $\begin{array}{l}\text { Inorganic } \\
\text { carbon, } \\
\text { as } \\
\text { percentage } \\
\text { of } \\
\text { oven-dried } \\
\text { mass as } \\
\text { carbon }\end{array}$ & $\begin{array}{l}\text { Total } \\
\text { nitrogen, } \\
\text { as } \\
\text { percentage } \\
\text { of } \\
\text { oven-dried } \\
\text { mass as } \\
\text { nitrogen }\end{array}$ & $\begin{array}{l}\text { Nitrite } \\
\text { plus } \\
\text { nitrate, } \\
\text { as } \\
\text { mg } \\
\text { nitrogen } \\
\text { per kg } \\
\text { of } \\
\text { oven-dried } \\
\text { mass }\end{array}$ & $\begin{array}{c}\text { Total } \\
\text { inorganic } \\
\text { phosphorus, } \\
\text { as } \\
\text { mg } \\
\text { phosphorus } \\
\text { per kg } \\
\text { of } \\
\text { oven-dried } \\
\text { mass }\end{array}$ & $\begin{array}{c}\text { Total } \\
\text { phosphorus, } \\
\text { as } \\
\text { mg } \\
\text { phosphorus } \\
\text { per og } \\
\text { of } \\
\text { oven-dried } \\
\text { mass }\end{array}$ \\
\hline NWR-01J & 16.40 & 16.70 & 0.30 & 47.8 & $\mathrm{~L}$ & HEMIC PEAT WITH CLAY & 42.0 & 4.3 & 0.0904 & 89.7 & 10.3 & 26.6 & - & 41.5 & - & 2.25 & 61 & - & 280 \\
\hline NWR-02A & 1.20 & 1.50 & 0.30 & 47.8 & $\mathrm{~L}$ & HEMIC PEAT & 40.5 & 3.2 & 0.0672 & 92.1 & 7.9 & 71.0 & - & 48.2 & - & 3.23 & 15 & - & 460 \\
\hline NWR-02B & 2.50 & 2.80 & 0.30 & 47.8 & $\mathrm{~L}$ & HEMIC PEAT & 41.7 & 5.0 & 0.1052 & 87.9 & 12.1 & 32.5 & - & 37.9 & - & 3.21 & 14 & - & 380 \\
\hline NWR-02C & 6.00 & 6.30 & 0.30 & 47.8 & $\mathrm{~L}$ & HEMIC PEAT & 48.0 & 5.1 & 0.1067 & 89.4 & 10.6 & 37.8 & - & 34.9 & - & 2.27 & 5 & - & 400 \\
\hline NWR-02D & 7.80 & 8.10 & 0.30 & 47.8 & $\mathrm{~L}$ & HEMIC PEAT & 46.0 & 4.0 & 0.0839 & 91.3 & 8.7 & 18.1 & - & 47.5 & - & 2.93 & 15 & - & 480 \\
\hline NWR-02E & 11.10 & 11.40 & 0.30 & 47.8 & $\mathrm{~L}$ & HEMIC PEAT & 46.4 & 5.2 & 0.1092 & 90.1 & 9.9 & 38.6 & - & 37.0 & - & 2.23 & 122 & - & 310 \\
\hline NWR-02F & 16.30 & 16.60 & 0.30 & 47.8 & $\mathrm{~L}$ & CLAY & - & - & & - & - & - & - & - & - & - & & - & \\
\hline NWR-03A & 1.00 & 1.30 & 0.30 & 47.8 & $\mathrm{~L}$ & HEMIC PEAT & 43.0 & 4.9 & 0.1026 & 88.6 & 11.4 & 20.2 & - & 43.5 & - & 3.19 & 56 & - & 970 \\
\hline NWR-03B & 2.80 & 3.10 & 0.30 & 47.8 & $\mathrm{~L}$ & CLAY & - & - & - & - & - & - & - & - & - & - & - & - & - \\
\hline NWR-03C & 11.40 & 11.70 & 0.30 & 47.8 & $\mathrm{~L}$ & CLAY & - & - & - & - & - & - & - & - & - & - & - & - & - \\
\hline SHO-01A & 2.20 & 2.50 & 0.30 & 47.8 & $\mathrm{~L}$ & HEMIC PEAT & 47.5 & 5.2 & 0.1091 & 89.0 & 11.0 & 15.0 & - & 46.7 & - & 3.34 & 238 & - & 520 \\
\hline SHO-01B & 4.30 & 4.60 & 0.30 & 47.8 & $\mathrm{~L}$ & HEMIC PEAT & 49.1 & 7.1 & 0.1488 & 85.5 & 14.5 & 33.1 & - & 38.0 & - & 2.33 & 226 & - & 350 \\
\hline SHO-01C & 7.30 & 7.60 & 0.30 & 47.8 & $\mathrm{~L}$ & SAPRIC PEAT & 38.8 & 6.9 & 0.1438 & 82.3 & 17.7 & 33.9 & - & 38.3 & - & 1.90 & 162 & - & 500 \\
\hline SHO-01D & 9.10 & 9.40 & 0.30 & 47.8 & $\mathrm{~L}$ & HEMIC PEAT & 52.1 & 6.9 & 0.1444 & 86.8 & 13.2 & 19.1 & - & 45.4 & - & 2.99 & 22 & - & 360 \\
\hline SHO-01E & 12.60 & 12.90 & 0.30 & 47.8 & $\mathrm{~L}$ & HEMIC PEAT WITH CLAY & 52.1 & 9.8 & 0.2057 & 81.1 & 18.9 & 78.4 & - & 10.3 & - & 0.95 & 20 & - & 130 \\
\hline SHO-01F & 13.80 & 14.10 & 0.30 & 20.6 & $\mathrm{~s}$ & SAND WITH CLAY? & - & - & - & - & - & - & - & - & - & - & - & - & - \\
\hline SQW-01A & 0.80 & 1.10 & 0.30 & 47.8 & $\mathrm{~L}$ & MUCK & 40.1 & 8.0 & 0.1674 & 80.0 & 20.0 & 69.8 & 5.5 & 11.6 & $<0.01$ & 1.27 & 73 & - & 660 \\
\hline SQW-01B & 1.90 & 2.20 & 0.30 & 47.8 & $\mathrm{~L}$ & CLAY & - & - & - & - & - & - & - & - & - & - & - & - & - \\
\hline SQW-01C & 2.40 & 2.70 & 0.30 & 47.8 & $\mathrm{~L}$ & SAPRIC PEAT & 42.7 & 10.3 & 0.2146 & 76.1 & 23.9 & 55.6 & - & 24.1 & - & 1.87 & 95 & - & 810 \\
\hline SQW-01D & 2.90 & 3.20 & 0.30 & 47.8 & $\mathrm{~L}$ & HEMIC PEAT & 45.4 & 6.1 & 0.1285 & 86.5 & 13.5 & 15.6 & - & 48.2 & - & 2.62 & 99 & - & 620 \\
\hline SQW-01E & 4.30 & 4.60 & 0.30 & 47.8 & $\mathrm{~L}$ & HEMIC PEAT WITH CLAY & 46.6 & 5.7 & 0.1194 & 87.7 & 12.3 & 80.9 & - & 8.8 & - & 1.11 & 123 & - & 310 \\
\hline SQW-01F & 9.30 & 9.60 & 0.30 & 47.8 & $\mathrm{~L}$ & CLAY & - & - & - & - & - & - & - & - & - & - & - & - & - \\
\hline WOC-01A & 0.30 & 0.90 & 0.60 & & D & SAPRIC PEAT & 71.6 & 42.6 & - & 40.4 & 59.6 & 57.9 & - & 23.80 & - & 1.73 & 71 & - & 720 \\
\hline WOC-01B & 1.70 & 2.00 & 0.30 & 47.8 & $\mathrm{~L}$ & CLAY & - & - & - & - & - & - & - & - & - & - & - & - & - \\
\hline WOC-01C & 2.40 & 2.70 & 0.30 & 47.8 & $\mathrm{~L}$ & CLAY & - & - & - & - & - & - & - & - & - & - & - & - & - \\
\hline WOC-02A & 0.70 & 1.70 & 1.00 & - & D & SAPRIC PEAT & 84.8 & 33.4 & - & 60.6 & 39.4 & 63.1 & 5.8 & 14.0 & $<0.01$ & 1.48 & 301 & - & 770 \\
\hline WOC-02B & 4.50 & 4.80 & 0.30 & 47.8 & $\mathrm{~L}$ & CLAY & - & - & - & - & - & 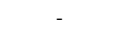 & - & - & - & - & & - & - \\
\hline WOC-03A & 0.60 & 0.90 & 0.30 & 47.8 & $\mathrm{~L}$ & SAPRIC PEAT & 34.0 & 13.1 & 0.2744 & 61.4 & 38.6 & 68.0 & - & 16.90 & - & 1.48 & 76 & - & 510 \\
\hline WOC-03B & 1.20 & 1.50 & 0.30 & 47.8 & $\mathrm{~L}$ & CLAY WITH HEMIC PEAT & 37.5 & 11.0 & 0.2311 & 70.5 & 29.5 & 76.1 & - & 10.50 & - & 1.12 & 74 & - & 230 \\
\hline WOC-03C & 3.60 & 3.90 & 0.30 & 47.8 & $\mathrm{~L}$ & HEMIC/SAPRIC PEAT & 47.1 & 9.4 & 0.1967 & 80.0 & 20.0 & 46.8 & 5.2 & 21.2 & $<0.01$ & 2.06 & 26 & - & 300 \\
\hline WOC-03D & 4.70 & 5.00 & 0.30 & 47.8 & $\mathrm{~L}$ & HEMIC PEAT WITH CLAY & 50.4 & 7.0 & 0.1472 & 86.0 & 14.0 & 53.4 & - & 23.90 & - & 1.57 & 12 & - & 210 \\
\hline WOC-03E & 5.70 & 6.00 & 0.30 & 47.8 & $\mathrm{~L}$ & HEMIC PEAT WITH CLAY & 54.2 & 12.9 & 0.2701 & 76.2 & 23.8 & 78.3 & - & 10.90 & - & 0.89 & 46 & - & 280 \\
\hline WOC- $03 \mathrm{~F}$ & 6.30 & 6.60 & 0.30 & 47.8 & $\mathrm{~L}$ & CLAY WITH SAND & - & - & - & - & - & - & - & - & - & - & - & - & - \\
\hline WOC-04A & 1.80 & 2.10 & 0.30 & 47.8 & $\mathrm{~L}$ & SAPRIC PEAT & 41.0 & 12.2 & 0.2553 & 70.3 & 29.7 & 44.1 & 4.6 & 26.3 & $<0.01$ & 2.01 & 90 & - & 470 \\
\hline WOC-04B & 2.10 & 2.40 & 0.30 & 47.8 & $\mathrm{~L}$ & SAPRIC PEAT & 43.6 & 10.2 & 0.2134 & 76.5 & 23.5 & 27.9 & 5.6 & 21.5 & $<0.01$ & 2.81 & 55 & - & 320 \\
\hline WOC-04C & 2.90 & 3.20 & 0.30 & 47.8 & $\mathrm{~L}$ & HEMIC PEAT WITH CLAY & 50.3 & 10.4 & 0.2176 & 79.4 & 20.6 & 67.4 & 6.0 & 11.6 & $<0.01$ & 1.23 & 55 & - & 170 \\
\hline WOC-05A & 2.60 & 2.90 & 0.30 & 47.8 & $\mathrm{~L}$ & CLAY & - & - & - & - & - & - & - & - & - & - & - & - & - \\
\hline WOC-06A & 0.40 & 0.70 & 0.30 & 47.8 & $\mathrm{~L}$ & SAPRIC PEAT & 50.6 & 21.4 & 0.4487 & 57.6 & 42.4 & 67.8 & - & 19.00 & - & 1.32 & 95 & - & 1,310 \\
\hline WOC-06B & 1.10 & 1.40 & 0.30 & 47.8 & $\mathrm{~L}$ & SAPRIC PEAT & 35.2 & 10.0 & 0.2100 & 70.5 & 29.5 & 35.7 & - & 34.70 & - & 2.23 & 85 & - & 570 \\
\hline WOC-07A & 0.70 & 1.30 & 0.60 & - & $\mathrm{D}$ & SAPRIC PEAT & 100.1 & 70.2 & - & 29.9 & 70.1 & 89.4 & - & 3.75 & - & 0.29 & 3 & - & 830 \\
\hline WOC-07B & 1.50 & 1.70 & 0.20 & - & D & MINERAL SOIL WITH SAND & 80.2 & 50.5 & - & 37.1 & 62.9 & 91.7 & - & 5.15 & - & 0.11 & 5 & - & 560 \\
\hline WOC-07C & 1.80 & 2.00 & 0.20 & - & D & SAND & 78.4 & 68.3 & - & 12.9 & 87.1 & 97.8 & 9.3 & $<0.01$ & 0.15 & $<0.01$ & 17 & - & 130 \\
\hline WOC-08A & 0.20 & 0.60 & 0.40 & - & D & SAPRIC PEAT & 93.5 & 55.2 & - & 40.9 & 59.1 & 73.7 & - & 17.60 & - & 0.89 & 38 & - & 1,390 \\
\hline WRM-02A & 1.20 & 1.50 & 0.30 & 47.8 & $\mathrm{~L}$ & HEMIC PEAT & 42.0 & 5.8 & 0.1210 & 86.2 & 13.8 & 61.0 & - & 19.7 & - & 1.54 & 11 & - & 690 \\
\hline WRM-02B & 2.90 & 3.20 & 0.30 & 47.8 & $\mathrm{~L}$ & CLAY WITH SAND & - & - & - & - & - & - & - & - & - & - & - & - & - \\
\hline WRM-02C & 4.60 & 4.90 & 0.30 & 47.8 & $\mathrm{~L}$ & CLAY WITH SAPRIC PEAT & 47.4 & 9.1 & 0.1904 & 80.7 & 19.3 & 74.6 & 4.7 & 9.2 & $<0.01$ & 1.08 & 17 & - & 330 \\
\hline WRM-02D & 6.30 & 6.60 & 0.30 & 47.8 & $\mathrm{~L}$ & SAPRIC PEAT & 45.9 & 7.5 & 0.1563 & 83.7 & 16.3 & 60.0 & - & 21.4 & - & 1.78 & 28 & - & 730 \\
\hline WRM-02E & 9.70 & 10.00 & 0.30 & 47.8 & $\mathrm{~L}$ & CLAY & - & - & - & - & - & - & - & - & - & - & - & - & - \\
\hline WRM-02F & 12.00 & 12.20 & 0.20 & - & D & CLAY & - & - & - & - & - & - & - & - & - & - & - & - & - \\
\hline
\end{tabular}




\begin{tabular}{|c|c|c|c|c|c|c|c|c|c|c|c|c|c|c|c|c|c|c|c|}
\hline $\begin{array}{l}\text { Sample } \\
\text { name }\end{array}$ & & $\begin{array}{l}\text { mple } \\
\text { pth } \\
\text { trt } \\
\text { Bottom }\end{array}$ & $\begin{array}{l}\text { Length } \\
\text { of sample } \\
\text { interval } \\
\text { (ft) }\end{array}$ & Volume & $\begin{array}{l}\text { Sample } \\
\text { method }\end{array}$ & Soil material & $\begin{array}{l}\text { Sample } \\
\text { weight } \\
\text { as } \\
\text { received } \\
\text { (g) }\end{array}$ & $\begin{array}{l}\text { Sample } \\
\text { weight } \\
\text { dry } \\
\text { (g) }\end{array}$ & $\begin{array}{c}\text { Bulk } \\
\text { density } \\
\text { (g per } \\
\text { cubic } \mathrm{cm} \text { ) }\end{array}$ & $\begin{array}{c}\text { Percent } \\
\text { moisture, } \\
\text { as } \\
\text { percentage } \\
\text { of } \\
\text { total mass }\end{array}$ & $\begin{array}{c}\text { Percent } \\
\text { dry matter, } \\
\text { as } \\
\text { percentage } \\
\text { of } \\
\text { total mass }\end{array}$ & $\begin{array}{l}\text { Percent } \\
\text { ash } \\
\text { content, } \\
\text { as } \\
\text { percentage } \\
\text { of } \\
\text { oven-dried } \\
\text { mass }\end{array}$ & $\begin{array}{c}\text { Soil } \\
\text { pH } \\
\text { (standard } \\
\text { pH units) }\end{array}$ & $\begin{array}{c}\text { Total } \\
\text { carbon, } \\
\text { as } \\
\text { percentage } \\
\text { of } \\
\text { oven-dried } \\
\text { mass as } \\
\text { carbon }\end{array}$ & $\begin{array}{l}\text { Inorganic } \\
\text { carbon, } \\
\text { as } \\
\text { percentage } \\
\text { of } \\
\text { oven-dried } \\
\text { mass as } \\
\text { carbon }\end{array}$ & $\begin{array}{c}\text { Total } \\
\text { nitrogen, } \\
\text { as } \\
\text { percentage } \\
\text { of } \\
\text { oven-dried } \\
\text { mass as } \\
\text { nitrogen }\end{array}$ & $\begin{array}{c}\text { Nitrite } \\
\text { plus } \\
\text { nitrate, } \\
\text { as } \\
\text { mg } \\
\text { nitrogen } \\
\text { per } \mathrm{kg} \\
\text { of } \\
\text { oven-dried } \\
\text { mass }\end{array}$ & $\begin{array}{c}\text { Total } \\
\text { inorganic } \\
\text { phosphorus, } \\
\text { as } \\
\text { mg } \\
\text { phosphorus } \\
\text { per kg } \\
\text { of } \\
\text { oven-dried } \\
\text { mass }\end{array}$ & $\begin{array}{c}\text { Total } \\
\text { phosphorus, } \\
\text { as } \\
\mathrm{mg} \\
\text { phosphorus } \\
\text { per kg } \\
\text { of } \\
\text { oven-dried } \\
\text { mass }\end{array}$ \\
\hline WRN-01A & 0.70 & 1.10 & 0.40 & - & D & SAPRIC PEAT & 75.5 & 40.8 & - & 46.0 & 54.0 & 53.3 & - & 24.4 & - & 1.84 & 71 & - & 1,070 \\
\hline WRN-01B & 0.70 & 1.10 & 0.40 & - & D & SAPRIC PEAT & 99.3 & 56.6 & - & 43.1 & 56.9 & 52.8 & - & 24.3 & - & 1.83 & 95 & - & 1,060 \\
\hline WRN-01C & 1.10 & 1.70 & 0.60 & & D & HEMIC/SAPRIC PEAT & 64.5 & 22.0 & & 66.0 & 34.0 & 57.3 & 5.4 & 17.8 & $<0.01$ & 1.53 & 129 & - & 640 \\
\hline WRN-01D & 2.70 & 3.00 & 0.30 & 47.8 & $\mathrm{~L}$ & $\begin{array}{l}\text { SAPRIC PEAT } \\
\end{array}$ & 51.6 & 11.7 & 0.2442 & 77.4 & 22.6 & 49.5 & - & 27.4 & - & 1.85 & 52 & - & 740 \\
\hline WRN-01E & 3.00 & 3.30 & 0.30 & 47.8 & $\mathrm{~L}$ & SAPRIC PEAT & 49.0 & 11.4 & 0.2385 & 76.8 & 23.2 & 56.9 & - & 22.70 & - & 1.59 & 46 & - & 590 \\
\hline WRN-01F & 6.00 & 6.30 & 0.30 & 47.8 & $\mathrm{~L}$ & HEMIC/SAPRIC PEAT & 52.0 & 8.6 & 0.1799 & 83.5 & 16.5 & 42.5 & 5.7 & 23.9 & $<0.01$ & 1.72 & 299 & - & 400 \\
\hline WRN-01G & 7.10 & 7.40 & 0.30 & 47.8 & $\mathrm{~L}$ & SAPRIC PEAT & 52.1 & 12.7 & 0.2659 & 75.6 & 24.4 & 49.4 & - & 26.30 & - & 1.95 & 168 & - & 700 \\
\hline WRN-01H & 8.00 & 8.30 & 0.30 & 47.8 & $\mathrm{~L}$ & HEMIC PEAT WITH CLAY & 49.1 & 8.1 & 0.1699 & 83.5 & 16.5 & 59.5 & - & 20.80 & - & 1.65 & 369 & - & 370 \\
\hline WRN-02A & 1.80 & 2.30 & 0.50 & & D & SAPRIC PEAT & 93.0 & 50.9 & - & 45.2 & 54.8 & 89.8 & - & 3.24 & - & 0.27 & 3 & - & 300 \\
\hline WRN-02B & 4.30 & 4.60 & 0.30 & 47.8 & $\mathrm{~L}$ & CLAY & 60.7 & 20.0 & 0.4185 & 67.1 & 32.9 & 82.7 & 5.6 & 5.7 & $<0.01$ & 0.49 & 19 & - & 270 \\
\hline WRN-02C & 5.80 & 6.10 & 0.30 & 47.8 & $\mathrm{~L}$ & CLAY WITH PUMICE SAND & - & - & - & - & - & - & - & - & - & - & 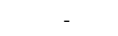 & - & 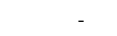 \\
\hline WRN-03A & 0.70 & 1.30 & 0.60 & - & D & SAPRIC PEAT WITH & & & & & & & & & & & & & \\
\hline & & & & & & PUMICE SAND & 88.7 & 69.4 & - & 21.7 & 78.3 & 92.0 & - & 2.75 & - & 0.27 & 13 & - & 1,210 \\
\hline WRN-03B & 2.90 & 3.40 & 0.50 & - & D & SAPRIC PEAT & 64.3 & 38.0 & - & 40.9 & 59.1 & 88.6 & - & 3.30 & - & 0.25 & 13 & - & 270 \\
\hline WRN-03C & 4.60 & 5.00 & 0.40 & & $\mathrm{D}$ & SAPRIC PEAT & 91.4 & 47.2 & - & 48.4 & 51.6 & 89.5 & - & 2.71 & - & 0.22 & 6 & - & 420 \\
\hline WRN-03D & 5.90 & 6.20 & 0.30 & 47.8 & $\mathrm{~L}$ & SAPRIC PEAT WITH CLAY & 68.8 & 30.0 & 0.6268 & 56.5 & 43.5 & 91.8 & - & 2.47 & - & 0.24 & 5 & - & 340 \\
\hline WRN-03E & 6.20 & 6.50 & 0.30 & 47.8 & $\mathrm{~L}$ & SAPRIC PEAT WITH CLAY & 71.6 & 30.4 & 0.6369 & 57.5 & 42.5 & 89.6 & - & 2.86 & - & 0.24 & 6 & - & 340 \\
\hline WRR-01A & 1.20 & 1.80 & 0.60 & - & $\mathrm{D}$ & PUMICE GRAVEL & - & - & - & - & - & - & - & - & - & - & - & - & - \\
\hline WRR-01B & 3.00 & 3.20 & 0.20 & 31.9 & $\mathrm{~L}$ & CLAY & - & - & - & - & - & - & - & - & - & - & - & - & - \\
\hline WRR-02A & 1.20 & 1.50 & 0.30 & 47.8 & $\mathrm{~L}$ & HEMIC PEAT WITH CLAY & 49.3 & 11.3 & 0.2364 & 77.1 & 22.9 & 72.6 & - & 13.2 & - & 1.12 & 73 & - & 490 \\
\hline WRR-02B & 2.70 & 3.00 & 0.30 & 47.8 & $\mathrm{~L}$ & HEMIC PEAT & 47.4 & 8.5 & 0.1772 & 82.1 & 17.9 & 63.8 & - & 19.8 & - & 1.61 & 30 & - & 300 \\
\hline WRR-02C & 7.00 & 7.30 & 0.30 & 47.8 & $\mathrm{~L}$ & SAPRIC PEAT WITH CLAY & 43.0 & 9.5 & 0.1988 & 77.8 & 22.2 & 77.1 & 5.3 & 8.7 & $<0.01$ & 0.78 & 42 & - & 180 \\
\hline WRR-03A & 0.30 & 0.60 & 0.30 & 47.8 & $\mathrm{~L}$ & HEMIC PEAT & 40.0 & 7.3 & 0.1526 & 81.8 & 18.2 & 19.0 & - & 42.8 & - & 2.68 & 156 & - & 700 \\
\hline WRR-03B & 2.10 & 2.40 & 0.30 & 47.8 & $\mathrm{~L}$ & HEMIC PEAT & 47.6 & 6.1 & 0.1276 & 87.3 & 12.7 & 33.9 & 4.7 & 26.3 & $<0.01$ & 2.17 & 57 & - & 440 \\
\hline WRR-03C & 2.40 & 2.70 & 0.30 & 47.8 & $\mathrm{~L}$ & HEMIC PEAT & 47.9 & 7.9 & 0.1653 & 83.5 & 16.5 & 41.9 & 4.6 & 25.0 & $<0.01$ & 2.12 & 13 & - & 350 \\
\hline WRR-03D & 7.40 & 7.70 & 0.30 & 47.8 & $\mathrm{~L}$ & CLAY & - & - & - & - & - & - & - & - & - & - & - & - & - \\
\hline WRR-03E & 12.90 & 13.20 & 0.30 & 47.8 & $\mathrm{~L}$ & CLAY & - & - & - & - & - & - & - & - & - & - & - & - & - \\
\hline WRR-03F & 14.90 & 15.20 & 0.30 & 47.8 & $\mathrm{~L}$ & CLAY WITH PUMICE SAND & - & - & - & - & - & - & - & - & - & - & - & - & - \\
\hline WRR-04A & 0.80 & 1.10 & 0.30 & 47.8 & $\mathrm{~L}$ & HEMIC PEAT & 45.3 & 5.5 & 0.1156 & 87.8 & 12.2 & 22.2 & - & 43.5 & - & 2.02 & 112 & - & 480 \\
\hline WRR-04B & 7.60 & 7.90 & 0.30 & 47.8 & $\mathrm{~L}$ & HEMIC/SAPRIC PEAT & 49.9 & 7.4 & 0.1539 & 85.3 & 14.7 & 50.0 & - & 27.3 & - & 1.22 & 10 & - & 420 \\
\hline WRR-05A & 2.80 & 3.10 & 0.30 & 47.8 & $\mathrm{~L}$ & SAPRIC PEAT & 40.1 & 8.4 & 0.1752 & 79.1 & 20.9 & 54.1 & - & 25.3 & - & 1.96 & 37 & - & 690 \\
\hline WRR-05B & 3.10 & 3.40 & 0.30 & 47.8 & $\mathrm{~L}$ & SAPRIC PEAT & 19.8 & 5.1 & 0.1072 & 74.1 & 25.9 & 66.2 & . & 18.3 & - & 1.46 & 29 & - & 740 \\
\hline WRR-05C & 5.00 & 5.30 & 0.30 & 20.6 & $\mathrm{~s}$ & PUMICE SAND & 170 & - & - & - & - & & - & 0.0 & - & - & 2 & - & \\
\hline WRR-08A & 1.00 & 1.30 & 0.30 & 47.8 & $\mathrm{~L}$ & HEMIC PEAT & 46.2 & 7.3 & 0.1527 & 84.3 & 15.7 & 60.2 & 5.2 & 15.0 & $<0.01$ & 1.85 & 48 & - & 480 \\
\hline WRR-08B & 1.30 & 1.60 & 0.30 & 47.8 & $\mathrm{~L}$ & HEMIC PEAT & 42.9 & 7.0 & 0.1465 & 83.8 & 16.2 & 66.8 & 5.1 & 12.0 & $<0.01$ & 1.43 & 55 & - & 390 \\
\hline WRR-08C & 7.50 & 7.80 & 0.30 & 47.8 & $\mathrm{~L}$ & SAPRIC PEAT & 50.3 & 10.8 & 0.2260 & $\begin{array}{l}78.5 \\
78.5\end{array}$ & 21.5 & 66.0 & 4.4 & 14.1 & $<0.01$ & 1.15 & 27 & - & 310 \\
\hline WRR-08D & 7.90 & 8.20 & 0.30 & 47.8 & $\mathrm{~L}$ & ASH CLAY & 34.0 & 9.2 & 0.1934 & 72.8 & 27.2 & 95.3 & - & 0.9 & - & 0.16 & 91 & - & 70 \\
\hline WRR-09A & 0.60 & 0.90 & 0.30 & 47.8 & $\mathrm{~L}$ & SAPRIC PEAT & 47.3 & 13.3 & 0.2783 & 71.8 & 28.2 & 56.7 & 5.5 & 17.6 & $<0.01$ & 1.69 & 54 & - & 750 \\
\hline WRR-09B & 0.90 & 1.20 & 0.30 & 47.8 & $\mathrm{~L}$ & SAPRIC PEAT & 46.1 & 11.3 & 0.2364 & 75.5 & 24.5 & 40.2 & 4.1 & 17.3 & $<0.01$ & 1.59 & 82 & - & 620 \\
\hline WRR-09C & 2.00 & 2.30 & 0.30 & 47.8 & $\mathrm{~L}$ & HEMIC PEAT & 51.5 & 9.7 & 0.2033 & 81.1 & 18.9 & 54.3 & - & 23.1 & - & 1.62 & 85 & - & 400 \\
\hline WRR-09D & 7.90 & 8.20 & 0.30 & 47.8 & $\mathrm{~L}$ & HEMIC PEAT & 0.0 & - & - & - & - & & - & 20.1 & - & - & 0 & - & \\
\hline WRR-10A & 1.10 & 1.40 & 0.30 & 47.8 & $\mathrm{~L}$ & HEMIC PEAT & 47.7 & 10.3 & 0.2146 & 78.5 & 21.5 & 64.8 & - & 18.1 & - & 1.37 & 54 & - & 560 \\
\hline WRR-10B & 3.80 & 4.10 & 0.30 & 47.8 & $\mathrm{~L}$ & CLAY WITH HEMIC PEAT & 55.0 & 17.7 & 0.3693 & 67.9 & 32.1 & 83.3 & - & 8.0 & - & 0.62 & 17 & - & 390 \\
\hline WRR-10C & 9.80 & 10.10 & 0.30 & 47.8 & $\mathrm{~L}$ & SAPRIC PEAT & 46.2 & 10.4 & 0.2176 & 77.5 & 22.5 & 66.6 & 5.7 & 14.7 & $<0.01$ & 1.05 & 58 & 257.7 & 390 \\
\hline WRR-10D & 11.00 & 11.30 & 0.30 & 47.8 & $\mathrm{~L}$ & CLAY & 40.2 & - & & - & 20.0 & & - & - & - & 1.0 & - & - & \\
\hline
\end{tabular}




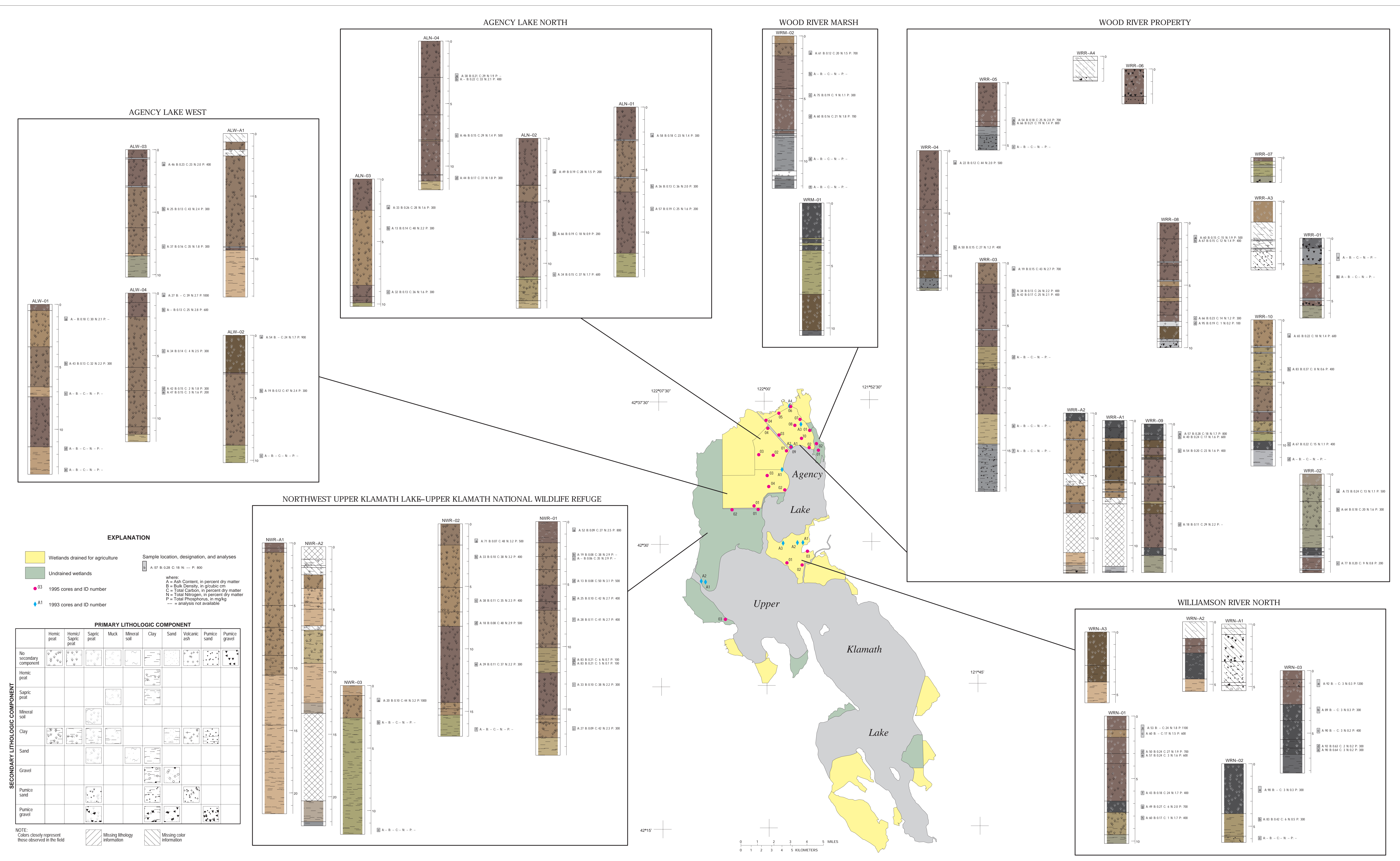




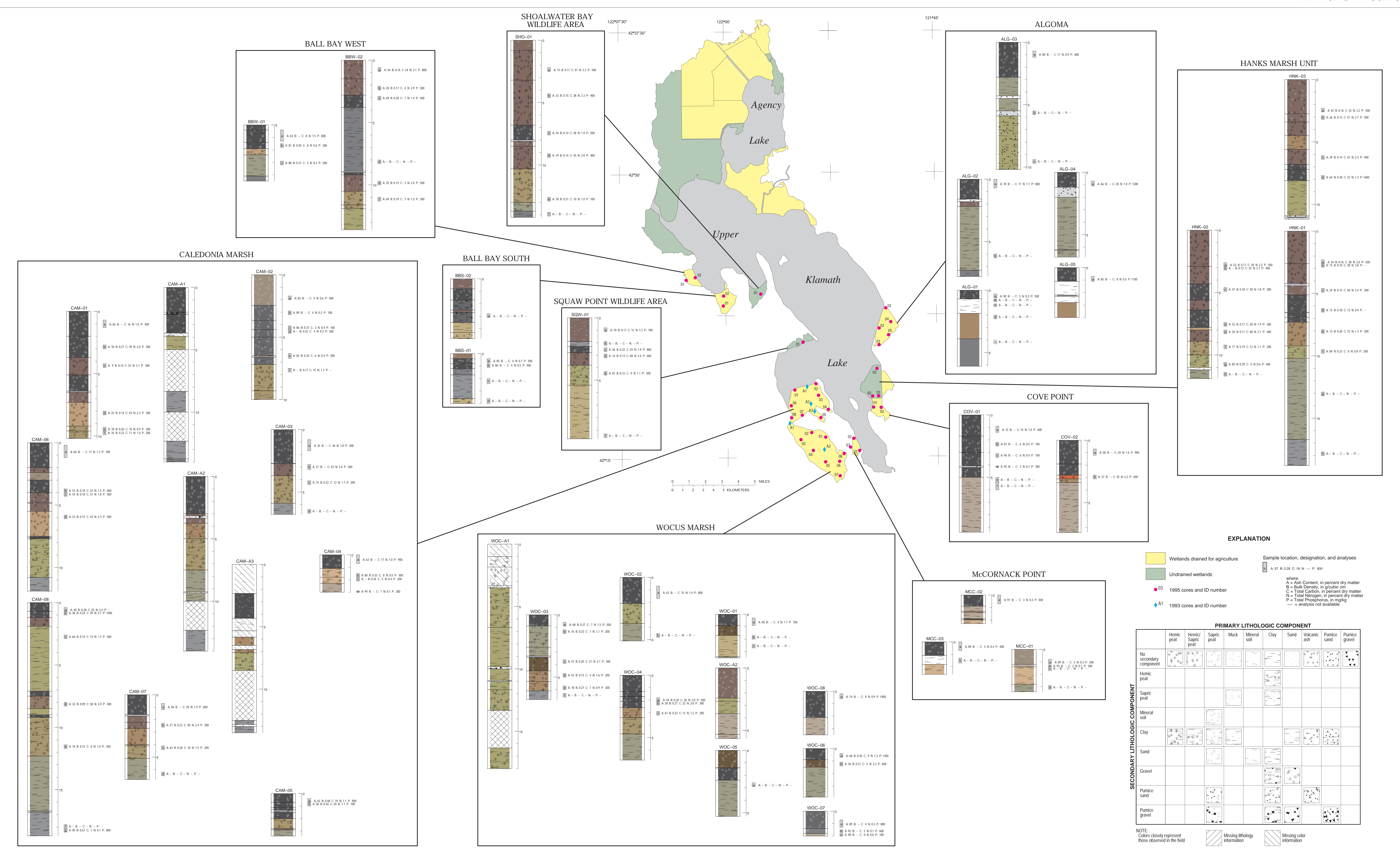

